\title{
BALKANSKA FEDERACIJA - ISTORIJA JEDNE IDEJE
}

dr Mirjana Zorić

Q alkan balkanskim narodima! Ova krilatica vezuje se za ideju o balkanskoj federaciji, koja je nastala u 19. veku, u vreme kada su balkanski narodi otpočinjali borbu za nacionalno oslobođenje od osmanske i habzburške vlasti. Ponikla je u krugovima levičarske (liberalne, socijalističke i socijaldemokratske) provenijencije, kao alternativa velikodržavnim pretenzijama nacionalnih elita koje su predvodile oslobodilačke pokrete na Balkanu. Njeni protagonisti pripadali su generaciji mladih intelektualaca koji su zagovarali federaciju balkanskih zemalja, ustanovljenu na principima socijalizma, društvene solidarnosti i ekonomske jednakosti, dakle, na modernim idejama koje je u to vreme promovisala evropska levica.

Početak 20. veka i Oktobarska revolucija u Rusiji 1917. godine dali su novi zamajac ideji o uspostavljanju federacije na Balkanu, a njen novi promoter ovoga puta bila je Kominterna (Komunistička internacionala, osnovana u Moskvi 1919), koja je okupljala komunističke partije u Evropi sve do 1943. godine. lako nosioci ove ideje u 20. veku postaju balkanski komunisti i njihove partije, ona je između dva svetska rata, u osnovi, bila podređena interesima sovjetske spoljne politike na Balkanu. Na kraju Drugog svetskog rata i u prvim godinama po njegovom završetku vođeni su intenzivni pregovori između komunističkih vlasti u Jugoslaviji i Bugarskoj o ujedinjenju njihovih država na federativnom principu, naravno, pod budnim okom sovjetskog lidera. Međutim, sukob jugoslovenskog vođstva sa Informbiroom, izolacija Jugoslavije, vojna i ekonomska blokada zemlje koju su uspostavile zemlje Istočnog bloka okončali su 1948. godine dalje pregovore o balkanskoj federaciji.

Najpribližnije i, moglo bi se reći, do sada jedino otelotvorenje ove ideje bila je južnoslovenska, odnosno jugoslovenska federacija - avnojevska (druga) Jugoslavija, utemeljena 1943/1945. godine. To je jedina federacija koja je istorijski bila ostvarena. Nažalost, njeno gotovo petodecenijsko iskustvo nije bilo dovoljno da federacija kao oblik državnog povezivanja međusobno bliskih naroda na Balkanu uhvati dublje i trajnije korene. Ipak, ideje o balkanskim asocijacijama prisutne su i danas. One rađaju nove inicijative o povezivanju i integrisanju zemalja Balkana, pre svega na ekonomskoj osnovi. $\mathrm{Na}$ njih blagonaklono gledaju i velike sile, naročito Evropska unija. Da li se time otvaraju mogućnosti za novu balkansku politiku zemalja regiona pokazaće vreme. Jedno je sigurno - ideje teško umiru, a za one dobre vredi se boriti!

Ključne reči: balkanska federacija, jugoslovenska federacija, konfederacija, ideje, projekti, socijalisti, komunisti, integracije, konferencija 


\section{Poreklo ideje o balkanskoj federaciji}

Ureme kada su balkanski narodi otpočinjali borbu za nacionalno oslobođenje od osmanske i habzburške vlasti, u 19. veku javile su se ideje o balkanskoj ili južnoslovenskoj federaciji, kao alternativa nacionalnom ekspanzionizmu vladajućih elita novoformiranih država na Balkanu. U osnovi svih zamisli o federaciji stajali su nada u slobodniji ekonomski razvoj i uverenje da će pomoću takve, višenacionalne zajednice svi nacionalni problemi biti rešeni. Južnoslovenska ideja temeljila se na etničkoj srodnosti i istorijskoj povezanosti južnoslovenskih naroda i predstavljala je jednu od varijanti ideje o balkanskoj federaciji. Nosioci te zamisli bili su uglavnom mlađi ljudi, obrazovani na vodećim evropskim univerzitetima, dakle, intelektualna predvodnica koja je u siromašnu i patrijarhalnu sredinu iz koje je ponikla donosila demokratske i liberalne ideje sa Zapada. Taj školovani svet vraćao se u malu i siromašnu Srbiju koja je bila poljoprivredno, zatvoreno i patrijarhalno društvo, pokušavajući da ukaže na nužnost privrednog povezivanja srodnih naroda i država koji dele slične običaje i kulturu. Prve zamisli o balkanskom federalizmu možemo pratiti u kontinuitetu od vremena kneza Mihaila i njegove druge vlade (1860-1868), od razvoja omladinskog pokreta i pojave prvih socijalista koji su bili pod jakim uticajem ruskog narodnjačkog socijalizma. Pioniri ove ideje bili su Hristo Botev u Bugarskoj i Svetozar Marković u Srbiji.

Ideje o balkanskom ujedinjavanju u to vreme ne mogu se pripisati isključivo levičarima. Njih su u pojedinim periodima zagovarali i drugi politički činioci, svakako u skladu sa interesima onih koji su ih zastupali. Parolu - „Balkan balkanskim narodima” prvi je promovisao i politički formalizovao knez Mihailo Obrenović, kada je od 1866. do 1868. godine potpisao niz ugovora sa balkanskim pravoslavnim zemljama - Crnom Gorom, Grčkom i Rumunijom, kao i sa bugarskom političkom emigracijom (Tajnim centralnim komitetom), radi formiranja Balkanskog saveza, sa Kneževinom Srbijom kao stožerom tog saveza. Prema zamisli kneza Mihaila, balkanski narodi bi se na ovaj način, udruženim snagama, aktivno uključili u rešavanje Istočnog pitanja. To će se ostvariti u Prvom balkanskom ratu (1912/13), kada su poslednji ostaci Turskog carstva na Balkanu likvidirani, a balkanske saveznice (Srbija, Bugarska, Grčka i Crna Gora) uspele da okončaju proces sopstvenog nacionalnog oslobođenja, započet još početkom 19. veka.

Nasuprot oslobodilačkim projektima sa nacionalnim predznakom, koji su pratili rađanje novih država i koji su međusobno izmešane narode na Balkanu obavezno uvodili u ratove, stajao je liberalno-socijalistički koncept koji je zagovarao suživot i saradnju balkanskih naroda, vođenje zajedničke politike i uklanjanje ekonomske i političke zavisnosti od velikih sila. To je, u osnovi, bio temelj ideje o balkanskoj federaciji. Ideja je nastala početkom šezdesetih godina 19. veka, kada su politički predstavnici slovenskih naroda u Habzburškoj monarhiji, u prvom redu Južni Sloveni i Česi, počeli odlučnije da zahtevaju svoja politička prava i reforme koje bi ovu državu pretvorile u ustavnu, parlamentarnu i federalističku državnu zajednicu. U tu svrhu pokrenut je, 1861. godine u Beču, i dnevni list Ost und West, a jedan od njegovih glavnih saradnika bio je i Mihailo Polit-Desančić (1833-1920), prvi teoretičar federalizma kod Južnih Slovena, svojevremeno najbliži saradnik Svetozara Miletića i vođa vojvođanskih liberala. ${ }^{1}$

\footnotetext{
${ }^{1}$ Mihailo Polit-Desančić pisao je za nemačke listove Deutsche Vierteljahrsschrift i Augsburger Allgemeinen Zeitungkao, kao i francuski I'Indépendance, u kojima je zastupao interese srpskog naroda. U Beču je doktorirao prava 1861. i odmah se uključio u politički život. Iste godine izabran je za poslanika u Hrvatskom saboru, gde je
} 
Dok su se Politovi prethodnici zanosili slavenofilskim i panslavističkim idejama, on je zagovarao koncepciju složene federacije balkanskih naroda koja bi se formirala na teritoriji tadašnje evropske Turske. Imajući u vidu međusobne odnose pojedinih balkanskih naroda u njegovo vreme, njihovu istoriju i savremena nacionalna stremljenja, Polit-Desančić je smatrao da bi Južni Sloveni, Rumuni i Grci trebalo da osnuju savez država, dok bi se Južni Sloveni međusobno ujedinili u zajedničku saveznu državu (po švajcarskom modelu konfederacije). Zajedno sa Svetozarom Miletićem, Vladimirom Jovanovićem (1833-1920), ideologom Liberalne stranke u Srbiji i profesorom na Velikoj školi i ostalim predstavnicima tadašnje srpske građanske elite naklonjene ovoj ideji, zamišljao je ostvarenje južnoslovenske federacije i balkanske konfederacije putem evolucije i sveobuhvatnih reformi.

Ideja Balkanske federacije deo je, pre svega, socijalističkog nasleđa Srbije u 19. veku, a njena geneza u kontinuitetu može se pratiti od Svetozara Markovića, preko Dimitrija Cenića, sve do Dimitrija Tucovića. Prve socijalističke ideje prepoznajemo kod Živojina Žujovića šezdesetih godina 19. veka, dok se početak socijalističkog pokreta u Srbiji vezuje za delovanje Svetozara Markovića (1846-1875). Posle početnog poleta 70-ih i 80-ih godina 19. veka, kome su glavni pečat dali Svetozar Marković i Mita Cenić, 90-ih godina nastalo je relativno zatišje u razvoju pokreta, sve do početka 20. veka. Majskim prevratom 1903. godine i uspostavljanjem parlamentarizma u Srbiji stvoreni su povoljniji uslovi za razvoj radničkog pokreta i za njegovu organizovaniju delatnost. Iste godine osnovana je i prva radnička stranka - Srpska socijaldemokratska stranka (koja će 1909. godine biti preimenovana u Srpsku socijaldemokratsku partiju), a njeno delovanje ostaviće dubok trag u političkom životu Srbije do početka Prvog svetskog rata, kao i tokom samog rata.

održao i svoj prvi politički govor o Vojvodini, naglašavajući potrebu za konstituisanjem srpske političke autonomije u Vojvodini, kao i priznavanjem narodnosti u Ugarskoj. Bio je jedan od rodonačelnika Srpske slobodoumne narodne stranke i dugo godina prvi saradnik njenog vođe Svetozara Miletića, a od 1887. osnivač i lider Srpske narodne liberalne stranke u Vojvodini.

Po uzoru na Štrosmajera, zalagao se za tesnu saradnju između Srba i Hrvata, smatrajući da ona može doneti koristi i jednom i drugom narodu. Od 1866. posvetio se više spoljnoj politici. Najviše ga je zanimalo Istočno pitanje. Tražio je od Austrougarske da pomogne hrišćanskim narodima u borbi protiv Otomanskog carstva, da balkanski narodi budu akteri u rešavanju ovog pitanja. Borio se protiv mađarizacije Srba, dualizma monarhije i teze o jedinstvenoj mađarskoj državi, tražeći da se ovo pitanje postavi pred evropskom javnošću. Učestvovao je na Slovenskom skupu 1867; bio je pristalica ruskog carizma i smatrao da Rusija, uz druge evropske sile, putem dogovora treba da oslobodi porobljene narode u Turskoj. Tada je upoznao cara Aleksandra Drugog. Zbog svojih govora na Moskovskom univrezitetu o potrebi skorog rešenja Istočnog pitanja morao je da napusti Zagreb i preseli se u Novi Sad, gde je 1870. položio advokatski ispit na mađarskom jeziku. U Novom Sadu Polit-Desančić je otvorio advokatsku kancelariju i postao jedan od najboljih srpskih pravnika i advokata u 19. veku. Briljantno je branio Miletića pred Okružnim sudom u Budimpešti (1876), kada je ovaj bio optužen zbog veleizdaje. Njegova odbrana bila je primer sudskog besedništva, postavljena na načelima antičke i klasične retorike.

U periodu od 1873. do 1913. godine gotovo stalno je biran za Ugarski sabor. Njegovi govori u ugarskom parlamentu bili su potkrepljeni pravnim dokazima i imali su jak odjek u javnosti. Tako je Josip Juraj Štrosmajer u pismu Franji Račkom jednom prilikom napisao da Polit više vredi nego svi hrvatski poslanici (njih 33) u Ugarskom saboru. Od 1903. bavio se političkim novinarstvom i advokaturom. Bio je jedan od najboljih vojvođanskih publicista, štampao je članke i rasprave iz političke istorije, a najviše vremena posvetio je novinarstvu. U vreme Prvog svetskog rata iz Novog Sada se preselio u Beč, gde se bavio i pisanjem memoara. Govorio je nemački, mađarski, francuski, ruski, engleski i italijanski, služio se rumunskim i slovačkim jezikom, a poznavao je i klasične jezike - starogrčki i latinski. Bio je dopisni član Srpskog učenog društva od 1869. i počasni član Srpske kraljevske akademije od 1892. godine. 
Pitanje koje je stalno bilo prisutno u delovanju balkanskih socijalista i socijaldemokrata u drugoj polovini 19. i početkom 20. veka, bilo je vezano za balkansku federaciju. U njoj su oni videli najprihvatljiviji oblik koji je rešavao nacionalno i državno pitanje balkanskih naroda koji su i ovom periodu prolazili kroz proces nacionalnog preporoda i formiranja nezavisnih država. Socijalistički koncept balkanske federacije dao je, zapravo, snažan pečat političkom životu Srbije u drugoj polovini 19. i početkom 20. veka. Dok su Mihailo Polit-Desančić, Svetozar Miletić, Vladimir Jovanović i ostali predstavnici ondašnje srpske građanske demokratije zamišljali ostvarenje južnoslovenske federacije i balkanske konfederacije putem evolucije i sveobuhvatnih reformi, prvi socijalisti - Svetozar Marković i Vaso Pelagić su smatrali da je taj cilj moguće ostvariti jedino putem socijalne revolucije.

Svoje poimanje federalizma na Balkanu i državotvornog ustrojstva srpskog naroda Svetozar Marković je detaljno obrazložio u poznatoj raspravi „Srbija na Istoku”, objavljenoj u Novom Sadu 1872. godine. U njoj je izričito odbacio povratak na „istorijska prava” kao ključni princip u stvaranju moderne srpske države, a ujedinjenje srpstva pozivanjem na Dušanovo carstvo smatrao je pogrešnim i štetnim, jer su Srbi u njegovo vreme živeli u četiri države (Austrija, Turska, Srbija i Crna Gora), pa su se njhova istorijska prava, s obzirom na te okolnosti, „teško mogla uskladiti". Ideji nacionalne države on je suprotstavio načelo federacije, koje srpski narod vodi u savez sa drugim balkanskim narodima ili u jugoslovenski savez, ali nikako u jednu srpsku državu. Za njega je etnički princip bio najvažniji nacionalni integracioni činilac.

Marković je upozoravao da srpski narod živi izmešan sa drugim balkanskim narodima, bez jasno određenih geografskih i etnografskih granica, te bi zato morao „uzeti ulogu osvajača” prema susedima ukoliko teži stvaranju velike nacionalne države: „Balkansko poluostrvo je mozaik od različitih naroda. Najveći brojem su Bugari; zatim dolaze Srbi i Grci skoro podjednako, zatim, Turci, Atnauti i Cincari. Koji će od tih naroda pristati da se anektira srpskoj monarhiji? Ne, ne! Srbija ne sme biti žrtvovana interesima nekoliko vlastoljubaca. Srpski narod nema drugog izlaska do revolucije na Balkanskom poluostrvu, koja bi završila uništenjem sviju država što danas smetaju da se ti narodi sjedine kao slobodni ljudi i ravnopravni radnici".

Marković je savetovao Srbe da se ne upuštaju u neproverene i sumnjive političke aranžmane pošto se u njima krije opasnost po njihove sopstvene državne interese. Odlučno se borio protiv teritorijalne ekspanzije Kneževine, protiv pripajanja Bosne i Hercegovine i protiv velikosrpske ideje: „Politička ideja da se osnuje Velika Srbija, tj da se od sadašnje Kneževine Srbije stvori jedna velika država jednostavnim zaposedanjem susednih srpskih zemalja, potpuno odgovara unutrašnjoj politici Srbije koja teži za tim da u zemlji utvrdi neograničenu moć dinastije Obrenović". Ispisujući ovakvu poruku u knjizi „Srbija na Istoku”, koja se može smatrati i njegovim političkim testamentom, Marković se rukovodio mogućim opasnostima koje su mogle zapretiti zbog nerealnih teritorijalnih pretenzija: „Srpski narod u Turskoj carevini jedva da broji više od 2.5 miliona ljudi. Pa recimo da srpska monarhija zadobije u svoju državu i ostale Srbe koji žive u Austrougarskoj, to je tek mala država od 5 miliona. Može li takva država da prisajedini sebi više od 10 miliona drugih narodnosti? Pa to bi bilo nešto nalik na Austriju ili Ugarsku, što po tvrđenju samih srpskih državnika ne može da postoji! Je li vredno da se srpski narod bori za takvu besmislicu samo zato što srpski državnici žele da oponašaju Kavura ili Bizmarka”. ${ }^{3}$

\footnotetext{
${ }^{2}$ Svetozar Marković, Načela narodne ekonomije, sveska II, Beograd, 1975, str. 180.

${ }^{3}$ Svetozar Marković, Srbija na Istoku, Beograd, 1965, str. 221.
} 
Iskustva i pouke iz prošlosti

Zalažući se i sam za oslobođenje Srba od osmanlijske i habzburške vlasti, Marković je izričito odbacio ulogu Kneževine Srbije kao „Pijemonta Južnih Slovena”. Umesto toga zagovarao je revoluciju sa ciljem da se stvori jedna balkanska federacija čiju bi okosnicu činila srpsko-bugarska federacija. Njoj bi prethodila „srpska federacija” - sastavljena od Srbije, Crne Gore, Bosne i Hercegovine - koja bi bila u konfederalnom odnosu sa Bugarskom. Balkanska federacija osnovala bi se, kako je pisao, „ne po nacionalnostima, no po stvarnim potrebama”. „I ova federacija” , isticao je Marković „može se vrlo lako raširiti u federaciju naroda na Balkanskom poluostrvu i još dalje ako se uzmu u račun naši susedi preko Save i Dunava." ${ }^{4}$

U srpsko-bugarskom jedinstvu i saradnji nalazio je pouzdane garancije za mir i prosperitet Balkanskog poluostrva. To je za njega bilo toliko prirodno i logično savezništvo da je olako prešao preko onih okolnosti (interesa velikih sila i borbe balkanskih političara da pridobiju njihovu naklonost, težnji balkanskih naroda da prisvoje što veći deo osmanske državne teritorije, nerešenog crkvenog pitanja u Turskoj i dr.) koje su mogle da poremete „srpsko-bugarsku idilu”, nastalu još za vreme boravka bugarskih revolucionara u Beogradu i Novom Sadu tokom šezdesetih godina 19. veka. Upravo su ove okolnosti veoma često kvarile odnose između Srbije i Bugarske, dovodeći ih povremeno i do sukoba, a u kritičnim trenucima i do teških ratnih razračunavanja. Sve je to Marković očigledno prenebregao, smatrajući lakomisleno da se njegovo prijateljstvo sa Ljubenom Karavelovim (bugarskim pesnikom, piscem, novinarom, etnografom, narodnim herojem i borcem za oslobođenje Bugarske od otomanske vladavine, koji je nekoliko godina proveo u Srbiji - u Beogradu i Novom Sadu) može lako preneti na većinu Srba i Bugara. Zbog toga se i njegov propust da upozori na okolnosti koje su mogle poremetiti srpsko-bugarske odnose pokazuje kao ozbiljan nedostatak koncepcije o balkanskoj federaciji. lako je bio politički realista, Marković je na ovom primeru iskazao donekle romantičarske, veoma naivne i teško ostvarive vizije.

U pogledu odnosa prema Hrvatima, Svetozar Marković je bio veoma skeptičan. Čini se da im nije mnogo verovao i smatrao ih je veoma nepouzdanim partnerom. lako je u svom konceptu balkanske federacije dopuštao mogućnost da se i Hrvati nađu u njoj, to je činio sa rezervom. O tome svedoči i jedan njegov citat iz „Radenika”: „Izričući ovo javno, mi smo u isto vreme odredili odnošaje spram Srba i Hrvata u Austriji. Mi ćemo s njima biti sve donde dok je njihova radnja upravljena na to da sadašnja Austrija nestane". Saradnju sa Hrvatima dopuštao je samo u slučaju podudaranja srpskih i hrvatskih interesa. U svim drugim situacijama ona bi bila potpuno isključena. Nije upadao u zamku internacionalizma i fantastičnih panslavističkih projekcija. Za njega je postojala jedino Srbija.

Markovićev koncept federacije proistekao je iz projekcije socijalne revolucije na Balkanu: garantovao je političke slobode svakom narodu u okviru nje, ali je u isto vreme bio i rešenje nacionalnog pitanja. O tome je pisao: „Praktični smisao socijalizma za unutrašnji i spoljni razvitak srpskog naroda sadrži se u ovome: socijalni preobražaj iznutra, na osnovu narodnog suvereniteta i opštinske samouprave, zatim revolucija u Turskoj i federacija na Balkanskom poluostrvu". ${ }^{6}$ Cilj revolucije na Balkanu, po njemu, jeste uništenje

\footnotetext{
${ }^{4}$ Svetozar Marković, „Socijalizam ili društveno pitanje”, [u:] Rad, br. 22, 1874.

${ }^{5}$ Svetozar Marković, Radenik, br. 3, 1871.

${ }^{6}$ S. Marković, „Socijalizam ili društveno pitanje”, [u:] Rad, br. 22, 1874.
} 
svih država koje smetaju da se balkanski narodi udruže kao slobodni ljudi i ravnopravni radnici, kao savez opština, ali i kao savez država. Bio je izričit u tome da se federacija ne zasniva na nacionalnom principu. Rešenje društvenog pitanja video je u narodnoj, socijalnoj državi (koju čini savez opština) i u narodnoj samoupravi. Suprotstavljajući „istorijskom pravu" moderno demokratsko načelo narodnog samoopredeljenja koje bi se temeljilo na slobodi, jednakosti i bratstvu među ljudima, federacija je za Markovića bila ideal, a za ujedinjenje srpskog naroda na Balkanu - nužnost.

Treba naglasiti da je u drugoj polovini 19. veka bilo i drugih inicijativa za formiranje balkanske federacije. U Beogradu su 1865. godine radikalni balkanski intelektualci, privrženi idealima Francuske revolucije, osnovali „Demokratsku Orijentalnu Federaciju”, predlažući formiranje federacije od Alpa do Kipra, na osnovama političkih sloboda i socijalne jednakosti. ${ }^{7} U$ Atini je 1884. godine osnovana „Orijentalna federacija”, na inicijativu grčkih intelektualaca i nekih balkanskih političara koji su zastupali buržoaski federalizam, zalažući se za nekakvu mešavinu demokratske politike i umerenog nacionalizma. ${ }^{8} \mathrm{U}$ Solunu je 1893. godine osnovana Unutrašnja makedonska revolucionarna organizacija (VMRO), čiji je cilj bio oslobođenje i ujedinjenje čitave Makedonije (Egejske, Pirinske i Vardarske), ${ }^{9}$ koja bi postala sastavni deo Balkanske federacije. ${ }^{10}$ U Francuskoj je 1894. godine konstituisana „Liga za Balkansku konfederaciju”, u kojoj su uzeli učešća grčki, bugarski, srpski, rumunski i jermenski socijalisti. Za predsednika Lige izabran je grčki soci-

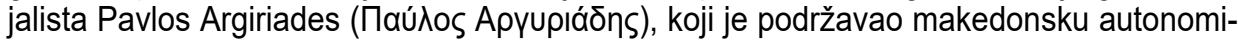
ju unutar balkanske federacije, kao jedino održivo rešenje makedonskog pitanja koje je uzrokovalo sporenja između Grčke, Srbije i Bugarske."

Posle smrti Svetozara Markovića, njegove pristalice su se podelile na dve struje: veću - radikalno/demokratsku ${ }^{12}$ i manju - socijalističku struju. Obe su tvrdile da su sledbenice Svetozara Markovića, ali se jedino grupa oko Dimitrija Mite Cenića otvoreno nazivala socijalističkom i konsekventno sprovodila politiku koju je u svojim delima utemeljio Svetozar Marković. U Cenićevim nastupima, govorima, člancima i političkim dokumentima često se pominjao koncept južnoslovenske i balkanske federacije. U programu socijalističke partije koju je Cenić pokušao da osnuje 1880. godine izričito se naglašavala potreba za stvaranjem federativne Jugoslavije, zahtevalo da se „birokratski sistem zameni narodnom samoupravom, a sadašnja politička konstelacija država na jugoistoku Evrope da se poništi i da se obrazuje federacija jugoslovenskih država sa potpunom samostalnošću pojedinih pokra-

\footnotetext{
${ }^{7}$ Vangelis Koutalis, Internationalism as an Alternative Political Strategy in the Modern History of Balkans, Greek Social Forum, Thessaloniki, june 2003; For "Democratic Oriental Federation", its Greek section "Rhigas", and "Oriental Federation" see Loukianos Hasiotis, The Oriental Federation: two Greek federalist movements of $19^{\text {th }}$ century (in Greek), Thessaloniki 2001.

${ }^{8}$ Isto.

${ }^{9}$ Kosta Cъrnušanov, Prinos kъm istorigta na Makedonskata Mladežka Taŭna Revolюcionna Organizacig, Makedonski Naučen Institut, Sofig, 1996.

${ }^{10}$ R.J. Crampton, A short history of modern Bulgaria, Cambridge, 1987.

${ }^{11}$ L.S. Stavrianos, Balkan Federation. A history of the movement towards Balkan unity in modern times, Menasha, Wisconsin 1944, str. 150-1; Dimitris Livanios, The Macedonian Question: Britain and the Southern Balkans 1939-1949, Oxfrd, 2008.

${ }^{12}$ Iz pokreta Svetozara Markovića nastaće 1881. godine antirežimska Narodna radikalna stranka koja je vremenom povukla masu radikalizovanog seljaštva u borbu protiv kraljevog apsolutizma i birokratskog režima u Srbiji.
} 
Iskustva i pouke iz prošlosti

jina". Cenić je po pitanju jugoslovenstva bio radikalniji od Svetozara Markovića. Dok je Marković često pisao o južnoslovenskim narodima koji bi se zajedno sa neslovenskim ujedinili u balkansku federaciju, Cenić najviše afirmiše ideju jugoslovenske države koja bi bila zaštitnica južnoslovenskih naroda. Bio je, pre svega, jugoslovenski orijentisan i protiv ideje da takva jugoslovenska zajednica služi bilo čijem interesu osim sopstvenom.

Dimitrije Cenić se suprotstavljao rusofiliji radikala, smatrajući da iza takve politike Rusije prema Srbiji stoji isključivo interes vladajućih klasa, a ne ruskog naroda. Tumačio je da povezanost unutrašnjeg društvenog razvoja sa spoljnopolitičkim okolnostima primorava srpski narod na stvaranje federacije na Balkanu. Princip revolucije i pravo na samoopredeljenje naroda predstavljali bi osnovu za njeno stvaranje. Uviđajući vezu između državnih i ljudskih prava, ideologije i politike, Cenić je pisao da se ne može težiti federaciji ukoliko u narodu nema svesti o potrebi za njom. Zato je insistirao na političkom osvešćivanju masa, kao metodi kojom se najefikasnije širi ideologija jugoslovenstva. Jugoslavija je za njega razrešenje svih protivurečnosti, ali isključivo ako je federativna. U takvoj državi niko ne bi bio manjina ni većina, nijedan narod ne bi bio politički, ekonomski ili kulturno potlačen. Po Dimitriju Ceniću, balkanska federacija bila bi tek naredna faza u povezivanju jugoslovenskih i drugih naroda na Balkanu: „Sve dok Balkan ne pripadne balkanskim narodima, na njemu neće biti mira", pisao je Cenić. Za razliku od ostalih protagonista federacije na Balkanu, on je smatrao da bi savezu balkanskih država nedvosmisleno trebalo da se pridruži i Turska. U daljoj perspektivi, po njemu, sledila bi čak i evropska integracija oličena u evropskoj federaciji, ali takva integrisana Evropa bila bi jedino moguća kao socijalistička federacija evropskih republika. Kao što je balkanska federacija rešenje za balkanske protivurečnosti, tako je i evropska socijalistička federacija rešenje svih evropskih protivrečnosti. „Jedino tako”, pisao je, „nestao bi jaz između malih država i velikih sila, između dominantnih i potlačenih naroda i svi bi dobili svoje mesto, svi narodi bi živeli zajedno". ${ }^{13}$

\section{Srpska socijaldemokratija o balkanskoj federaciji i ratu}

Od smrti Dimitrija Cenića (1888), pa sve do stvaranja Socijaldemokratske stranke Srbije 1903. godine (Srpske socijaldemokratske partije 1909), vladalo je zatišje u borbi za socijalizam u Srbiji i balkansku federaciju. Tadašnje socijaldemokratske partije u Austrougarskoj i na Balkanu zalagale su se više za decentralizaciju i redefinisanje odnosa unutar Habzburškog i Osmanskog carstva, a njihovi zahtevi bili su mnogo manje radikalni od onih koje su postavljali Marković, Cenić ili Ljuben Karavelov. U vreme svog osnivanja (nakon Majskog prevrata 1903. godine) Socijaldemokratska stranka Srbije se oslanjala na tradiciju socijalističkog pokreta u Srbiji iz 19. veka i njegove nosioce - Markovića, Pelagića i Cenića, ali se u velikoj meri razlikovala od njih, jer je nastajala i stasavala u drugačijim uslovima u odnosu na one devetnaestovekovne.

Od sredine 90 -ih godina 19. veka pojavljuje se i marksizam kao novi filozofski pravac u ideološkim strujanjima, koji počinje da prihvata i intelektualna elita u Srbiji. Zahvaljujući povoljnijim društvenim uslovima, u julu 1903. godine održan je osnivački kongres Srpske socijaldemokratske stranke, koja će na prvim parlamentarnim izborima već u septembru

${ }^{13}$ Dimitrije Mita Cenić, Izabrani spisi, Beograd, 1988. 
mesecu iste godine dobiti jedan mandat u Narodnoj skupštini. Ulaskom u parlament, stranka je stekla mogućnost da se legalno i legitimno bori za ostvarenje svojih ideja. Dok su socijalisti Svetozara Markovića šezdesetih godina 19. veka bili pod snažnim uticajem ruskog revolucionarnog narodnjaštva, Tucovićevi socijaldemokrati (SSDP) početkom 20. veka slede moderne zapadnoevropske ideološke tendencije. U duhu nove političke ideologije, utemeljene na spisima nemačkog filozofa Karla Marksa, oni su kapitalizam doživljavali kao pretpostavku, polazište ka razvoju socijalizma i u tom smislu su delovali u parlamentu, zalažući se najpre za usvajanje radničkog zakonodavstva. U svojim glasilima (novinama) i parlamentu borili su se protiv militarizma, velikodržavlja i rata, čiji su se oblaci već nadvijali nad Evropom. Propagirali su privredno jedinstvo Balkana i federaciju balkanskih i južnoslovenskih naroda. Za svoje vreme predstavljali su ne samo političku, već i društvenu i kulturnu avangardu u Srbiji i uticali na pluralizaciju njenog društva.

Srpska socijaldemokratska partija bila je članica Druge internacionale, međunarodne organizacije socijalističkih i radničkih partija osnovane u Parizu 1889. godine. Ideju o balkanskoj federaciji baštinila je od svojih prethodnika, socijalista Markovića, Pelagića i Cenića, dajući značajan doprinos njenom daljem razvoju. Najveći zagovornik balkanske federacije i njen teoretičar bio je Dimitrije Tucović. Za razliku od Svetozara Markovića i njegovog koncepta o federaciji slobodnih naroda, Tucovićevo tumačenje federacije bilo je proizvod zrelijih društvenih prilika u Srbiji s početka 20. veka. Vremenom se od opštih teorijskih postavki borba za balkansku federaciju pretvorila u akcioni program SSDP, po kojem će se ona dijametralno razlikovati od nacionalne politike koju su balkanski vladajući krugovi vodili u vreme balkanskih ratova i pred Prvi svetski rat.

U odnosu na neposredno spoljnopolitičko okruženje, naročito politiku velikih sila prema Balkanu, Dimitrije Tucović je ponudio savez balkanskih država koji bi nastao kao plod klasne borbe njihovog proletarijata. Smatrao je da problemi Balkana, zbog njegovog izuzetnog strateškog položaja, nisu samo balkanski i da balkanske države, sa svojim unutrašnjim, klasnim i političkim suprotnostima, nisu sposobne da samostalno reše nacionalno pitanje u sopstvenim sredinama. Zato je, po njemu, spas Balkana ležao u međusobnoj saradnji i zbližavanju naroda koji žive na ovom poluostrvu. I on je, baš kao i Svetozar Marković i Dimitrije Cenić pre njega, smatrao da se oslobođenje balkanskih naroda može ostvariti samo putem revolucije. Međutim, Tucovićev koncept bio je više proizvod zrelijih društvenih odnosa nego što je to bio Markovićev i Cenićev. Zato su Tucović i SSDP mogli da ponude i konkretnija rešenja za revolucionarno oslobođenje naroda na Balkanu i njihovo udruživanje u balkansku federaciju. ${ }^{14}$ Tucović je znao da će balkanska zajednica (federacija) biti moguća tek kada narodi Balkana postanu gospodari svoje sudbine: „Balkansku federaciju moći će balkanske države da ostvare samo onda, i tek onda, kada u njima u punoj meri bude vladala sloboda i demokratija, kad narodi budu upravljali svojom sudbinom, a ne njihovi kapitalisti" ${ }^{15}$ Osnovni princip u rešavanju nacionalnog pitanja zasnivao se, po njemu, na samoopredeljenju naroda, modernom načelu koje politička praksa do tada nije poznavala.

Već su 1907. godine, na kongresu Druge internacionale u Štutgartu, bugarska i srpska delegacija razgovarale o potrebi održavanja jedne socijalističke konferencije koja bi se pozabavila položajem balkanskih naroda u Evropi. Ubrzo je usledila velika međunarodna poli-

14 „Balkanska federacija”, Radničke novine, br. 151, 23. decembar 1909.

${ }^{15}$ Dimitrije Tucović i Balkanska federacija, Izabrani spisi, 1, Beograd, 1950, str. 134. 
tička kriza povodom aneksije Bosne i Hercegovine i Mladoturske revolucije (1908) u kojoj se rukovodstvo SSDP nije najbolje snašlo. Početkom 1909. godine, pod uticajem Socijaldemokratske partije Nemačke, rukovodstvo SSDP se ponovo vraća u okvire svoje prethodne politike; dolazi do zbližavanja među socijalistima balkanskih država i, na inicijativu Dimitrija Tucovića, u Beogradu je januara 1910. godine održana Prva balkanska socijaldemokratska konferencija. Tom prilikom je doneta i Rezolucija o borbi socijaldemokratskih partija za ujedinjenje balkanskog prostora u Savez slobodnih balkanskih naroda - Balkansku socijalističku federaciju, koja bi bila brana međusobnim sukobima i imperijalističkim intervencijama spolja. ${ }^{16}$ Konferencija je okupila 34 delegata iz Srbije, Crne Gore, Makedonije, Bugarske, Rumunije, Turske, Hrvatske, Slovenije, Bosne i Hercegovine, a njeni zaključci predstavljali su pokušaj da se osnaže mali balkanski narodi, rascepkani i razjedinjeni, kako bi se udruženim snagama izborili protiv šovinizma lokalnih režima i osvajačke politike velikih evropskih sila koje su se međusobno borile za uticaj na Balkanu. Učesnici Konferencije su se složili da ostvarenje suživota različitih nacija i kultura podrazumeva ukidanje granica koje su u prethodnom periodu, po njima, nasilno bile iscrtane. Nacionalno pitanje su definisali kao demokratsko pravo svakog naroda da ostvari svoje političko i nacionalno jedinstvo. U izrazito (nacionalno i verski) mešovitim sredinama na Balkanu smatrali su da jedino moguće rešenje leži u zajedničkoj federalnoj državi. ${ }^{17}$

Kao partija radničke provenijencije, Srpska socijaldemokratska partija bila je okrenuta, pre svega, borbi za poboljšanje položaja radničke klase, ukidanje klasne vladavine i promeni društvenih odnosa u celini, ali će njene aktivnosti u periodu od 1903. do 1914. godine, sticajem okolnosti, imati i mnogo širu dimenziju. Uporedo sa svakodnevnom borbom za radnička prava, partija je u ovom periodu bila prinuđena da zauzme aktivan stav i prema nacionalnom pitanju na Balkanu, kao i ratovima koji su bili u toku (balkanski ratovi) ili će tek uslediti (Prvi svetski rat).

U nacionalnoj politici SSDP se zalagala za pravo naroda na samoopredeljenje i sve do 1918. godine ostala je dosledna svojoj antiratnoj politici. U skladu sa stavovima Druge internacionale o suprotstavljanju potencijalnim međunarodnim ratovima, sve balkanske socijaldemokratske partije, pa i SSDP, uzrok ratova nalazile su u borbi velikih (imperijalističkih) sila za preraspodelu kolonija, osvajanje novih tržišta i izvora sirovina, ali i u „militarističkoj politici" domaćih dinastija i buržoazije. Uz osudu aneksije Bosne i Hercegovine (1908), SSDP se suprotstavljala i „šovinističkim erupcijama” u Srbiji i Bugarskoj 19121913. godine (u vreme balkanskih ratova), kao i vojnom pohodu srpske vojske u Albaniji 1913. godine. Ratnohuškačka politika vodećih sila toga vremena samo je dodatno podgrevala nacionalizam malih balkanskih država koje su pokušavale da, uz oslonac na neku od velikih sila zaštitnica, zauzmu što bolju poziciju u borbi za teritorije na kojima je živelo etnički mešovito stanovništvo. Balkanske socijaldemokratske partije su rešenje nacionalnog pitanja balkanskih naroda videle na način drugačiji od nasilne uspostave etnički čistih i odeljenih država.

\footnotetext{
${ }^{16}$ https://www.scribd.com/document/299590025. Resolution of the First Balkan Social Democratic Conference, u: Andreja Živković, Dragan Plavšić (eds), The Balkan Socialist Tradition: Balkan Socialism and the Balkan Federation, 1871-1915 (Revolutionary History, Vol. 8, No. 3, Porcupine Press, Socialist Platform Ltd, 2003), str. 164-166.

${ }^{17}$ L.S. Stavrianos, Balkan Federation. A history of the movement towards Balkan unity in modern times, Menasha, Wisconsin 1944, Appendix C, Resolution of the congress, str. 186.
} 
Borba SSDP protiv rata nije potekla samo od načelne vernosti principima međunarodnog radničkog pokreta. Ona je imala i svoja autentična izvorišta. Suočavajući se najpre (u vreme svog osnivanja) sa llindenskim ustankom u Makedoniji (1903), stav koji je Partija zauzela po tom pitanju vodio je ka priznavanju prava Makedoniji na sticanje autonomije. ${ }^{18}$ U vreme aneksije Bosne i Hercegovine Tucović je sugerisao vojno nemešanje srpske države, pružajući ipak podršku narodima u $\mathrm{BiH}$ u borbi za sopstveno oslobođenje. ${ }^{19}$

Prvi veliki test za srpske socijaldemokrate, kada je u pitanju njihova antiratna politika, bili su balkanski ratovi. Naime, rat koji su Srbija i druge balkanske države povele protiv Osmanskog carstva 1912. godine srpski socijaldemokrati su, uglavnom, kritikovali, mada je bilo i disonantnih tonova unutar samog vođstva SSDP-a. Pošlo se, uglavnom, od pretpostavke da će rezultat Prvog balkanskog rata biti stvaranje novih malih nacionalnih država sa međusobnim teritorijalnim sporovima koji će se i dalje nastavljati. Dimitrije Tucović je govorio da „ako bi se Maćedonija prisajedinila Bugarskoj, onda bi na svakog jednog Bugarina, koji je bio oslobođen, dolazilo po jedan ili više zarobljenih Srba, Grka, Rumuna, Turaka itd. Ako bi se Stara Srbija pridružila Srbiji, onda bi opet na jednoga slobodnoga Srbina dolazilo po dva porobljena Arnautina, Turčina itd. Mi hoćemo slobodu svakoga naroda ne uništavajući slobodu drugih". ${ }^{20}$ SSDP nije prihvatala rat koji su balkanske buržoazije i dinastije pokrenule radi ostvarenja sopstvenih, ali i ciljeva velikih sila koje su ih podržavale, a koji je vodio novom vidu porobljavanja, navodno oslobođenih naroda (posebno makedonskog i albanskog).

Oslanjajući se na Tucovićeve analize, partija je krivce za eventualni balkanski rat protiv Turske videla u ekspanzionizmu buržoazije malih balkanskih država i u imperijalizmu velikih evropskih sila. Na toj osnovi izgradila je sopstveni antiratni stav, što ne znači da je na Tursku kao „žrtvu” ovog rata gledala blagonaklono. Naprotiv. Srpski socijalisti su u većini odbacili rat kao metod rešavanja bilo kog pitanja, smatrajući da se problemi ne mogu rešiti oružjem i „donošenjem slobode”, nego narodnom demokratskom revolucijom „odozdo", koja bi obuhvatila čitav Balkan i kojom bi se stvorila balkanska socijalistička federacija. SSDP je upozoravala srpsku vladu da „deleći Balkan na pojedine male zemlje, vi ćete u tome stvoriti izvore za nova trvenja među balkanskim narodima (...) lći će posle Srbi da oslobađaju Srbe ispod bugarske vladavine, a Bugari će ići da oslobađaju Bugare ispod srpske vladavine. I onda će to izazivati neprestana trvenja”. ${ }^{21}$ Uz to, pretila je opasnost da se balkanski rat može pretvoriti u evropski rat.

Početkom jula 1912. godine, pre nego što je otpočeo Prvi balkanski rat, srpski socijaldemokrati su u skupštini zagovarali stvaranje balkanske federacije i protivili se vojnim izdacima namenjenim za ratovanje. Poslanik SSDP-a Dragiša Lapčević se oštro protivio ratu sa Turskom, zalažući se za demokratsku federaciju balkanskih država koja bi služila kao zajednička carinska unija: „Deleći Balkan na pojedine male zemlje, vi ćete stvoriti izvore za nova trvenja među balkanskim narodima i balkanskim državicama”, govorio je Lapčević u Narodnoj

\footnotetext{
${ }^{18}$ Zorica Priklmajer-Tomanović, Radnički pokret i jugoslovenskim zemljama do 1914. godine, u: Priručnik za istoriju međunarodnog radničkog pokreta, Beograd, 1964, str. 442.

${ }^{19}$ Sergije Dimitrijević, Socijalistički radnički pokret u Srbiji 1870-1918, Beograd, 1982, str. 191-194.

${ }^{20}$ Navedeno prema: Dubravka Stajić, Istorija socijaldemokratije. Sto godina od osnivanja SSDP - tuga i opomena; u: Republika, Beograd, godina XV, br. 314-315, avgust 2003.

${ }^{21}$ Navedeno prema: S. Dimitrijević, Socijalistički radnički pokret u Srbiji 1870-1918, str. 205.
} 
skupštini. Opominjao je da niko ne može biti zadovoljan granicama koje će se na taj način postaviti i da svaki rat vodi samo u novi rat. Podsećao je da na Balkanu žive izmešani narodi i da svaka nacionalna država, oslobađajući jedne, zapravo porobljava druge narode.

Rat je ipak započeo, a Dimitrije Tucović se i dalje protivio međusobnom otimanju oko teritorija, zalažući se za zajednicu balkanskih naroda: „Neprirodne pretpostavke dovode nas u neprirodni položaj. Svaka balkanska državica htela bi sve ono što samo u zajednici može dobiti. I mesto jedne logične težnje da se putem zajednice i ide, balkanska buržoazija stvara ratne situacije i gura u propast narode zbog svoje strahovite nesposobnosti da se uzdigne na visinu smelih pregnuća koja Istorija iziskuje. Nikada jedna klasa nije bila kratkovidija! Hoće svi pristaništa, svi dovoljno teritorija, svi Solun, svi Vardarsku dolinu, jer je sve to tako važno - a ne vide da to svi mogu imati samo u zajednici". ${ }^{22}$

Drugi balkanski rat predstavljao je potvrdu opravdanosti ovakvih stavova. Naime, pogoršane odnose među balkanskim saveznicama koje se nisu mogle dogovoriti oko podele oslobođenih teritorija po završetku Prvog balkanskog rata nastojala je da iskoristi Austrougarska. U strahu od ratnih uspeha srpske vojske i uvećanja srpske državne teritorije, monarhija je podržavala teritorijalne zahteve Bugarske za vardarskom Makedonijom, u želji da razbije Balkanski savez i oslabi Srbiju. Rusija je, pak, nastojala da ga sačuva, kao prepreku austrougarskom prodiranju na istok. Ubrzo je došlo do međusobnog obračuna doskorašnjih saveznika (Drugi balkanski rat) oko podele teritorija oslobođenih u Prvom ratu. Uskogrudost balkanskih nacionalizama, oslonjenih na podršku sa Zapada i Istoka, umesto na međusobni dogovor i saradnju, pokazala se u ovom ratu u punom svetlu.

Srpska socijaldemokrtska partija istovremeno je protestvovala i zbog pohoda srpske vojske preko Albanije na Jadransko more u jesen 1912. godine. Tumačila je da se pokušaji srpske buržoazije, dvora i vlade da se domognu izlaza na more ne mogu tolerisati ukoliko oni podrazumevaju porobljavanje albanskog naroda koji im se „isprečio na tom putu”. Naime, u novembru 1912. godine snage Primorskog kora srpske vojske izbile su na Jadransko primorje i okupirale severne delove Albanije, izuzev Skadra. Uprkos odluci velikih sila s kraja 1912. da se formira autonomna Kneževina Albanija, okupacija njene teritorije od strane srpske vojske trajala je do oktobra 1913. godine. Poslanici SSDP-a Triša Kaclerović i Dragiša Lapčević javno su iznosili „dokaze” u Narodnoj skupštini o zlodelima koje je srpska vojska u tom periodu počinila nad albanskim stanovništvom, što je izazvalo žestoke reakcije u javnosti, kako domaćoj, tako i stranoj. Lapčević je u skupštinskom govoru početkom 1914. godine, u debati povodom srpsko-albanskog sukoba iz 1913. godine, konstatovao da je ta politika bila „pogrešna, štetna i nesrećna, kako za slobodu albanskog naroda, tako i za mir i spokojstvo srpskog naroda", ${ }^{23}$ sluteći da to neće biti i poslednji sukob među njima. Istorija mu je, nažalost, dala za pravo.

Ovim događajima Dimitrije Tucović je posvetio svoju studiju „Srbija i Arbanija”, u kojoj je tumačio istoriju albanskog naroda i srpsko-albanskih odnosa i kritikovao srpsku okupaciju severne Albanije 1912-1913. godine. ${ }^{24}$ Za njega je srpska „okupacija” albanskog primorja predstavljala dokaz kako „nacionalno oslobođenje i ujedinjenje koje traži za svoj narod, kapitalistička buržoazija odriče drugim narodima (...) I kao što proletarijat u nekoj

\footnotetext{
${ }^{22}$ Dimitrije Tucović, Izabrani spisi, knjiga II, Beograd, 1950, str. 138.

${ }^{23}$ Isto, str. 214.

${ }^{24}$ Dimitrije Tucović, Srbija i Arbanija. Jedan prilog kritici zavojevačke politike srpske buržoazije, Beograd, 1914.
} 
zemlji predstavlja jedinu društvenu klasu koja se ne može boriti za oslobođenje iz klasnog ropstva a da ne oslobodi celo društvo, tako i socijalna demokratija ne može zastupati slobodu svoga naroda a da ne zastupa nacionalnu slobodu i svih drugih naroda. $U$ tome je jedna od bitnih razlika u gledištima socijalne demokratije i buržoaskih partija na nacionalno pitanje”. ${ }^{25} \mathrm{Na}$ ovaj način je Albanija, komentarisao je Tucović, „blagodareći u prvom redu zavojevačkim apetitima balkanskih državica, postala balkanskom predstražom dveju velikih evropskih sila, Austro-Ugarske i Italije". ${ }^{26}$

Umesto zavojevačke politike, Tucović je ponudio stvaranje nove zajednice na temeljima srušenog „turskog gospodstva”, koja bi predstavljala rešenje složenog balkanskog pitanja, „kojim bi svi balkanski narodi dobili najpovoljnije pogodbe za mirno i uspešno razvijanje u budućnosti”. Tvrdio je da bi se samo na taj način „mogla sačuvati davno izgubljena nacionalna sloboda, da se opet ne utopi u kakvoj međusobnoj otmici oko zadobivenih oblasti, otmici koja je najveća nesreća po slobodu balkanskih naroda. Ta sloboda je otmičarskim grabežom osvojenih oblasti udavljena pre nego što se bila rodila, a time je istorijski potvrđeno gledište socijalne demokratije da nacionalno oslobođenje balkanskih naroda nije moguće bez ujedinjenja celog Balkana u jednu opštu zajednicu. Takva narodna zajednica u isto vreme oslobodila bi sve narode i oblasti Balkanskog poluostrva uzajamnog stešnjavanja i zatvaranja koje često granice sa sobom nose i svima otvorila slobodan izlazak na more. Balkan bi postao jedna prostrana privredna oblast u kojoj bi moderni privredni život dobio poleta, i svaki deo te oblasti dobio bi u celini jemstva za slobodu saobraćaja, za osiguranje privrednih potreba, za brže privredno razvijanje uopšte. Istinska ekonomska emancipacija balkanskih naroda leži u privrednoj zajednici Balkana. A sa ujedinjenjem političkih snaga i privrednim napretkom balkanski narodi bi bili sposobni da dadu otpora zavojevačkim težnjama kapitalističkih evropskih država. Ako ima političkog realiteta na Balkanu, to je nužnost zajednice balkanskih naroda." ${ }^{27}$ Ovom porukom balkanskim narodima, Dimitrije Tucović kao da je ispisao i politički testament na čijem konceptu će se, u osnovi, temeljiti sve buduće inicijative i vizije balkanske federacije.

Doslednost u antiratnoj politici SSDP-a iskazana je naročito po pitanju ulaska Srbije u Prvi svetski rat. Za razliku od drugih evropskih socijaldemokratskih partija, koje su se svrstale na stranu vladajućih režima u svojim državama, SSDP je, posle socijaldemokratske radničke partije Rusije, bila jedina partija Druge internacionale koja se javno izjasnila protiv rata i glasala protiv ratnih kredita u nacionalnom parlamentu. Takav stav predstavljao je samo nastavak njene principijelne antiratne i antimilitarističke politike koju je partija demonstrirala u vreme balkanskih ratova. Otpočela je u Skupštini i van nje otvorenu borbu protiv rata, uprkos činjenici da je Srbija u njemu bila napadnuta i da se morala braniti. Ovakav stav nije nailazio na razumevanje domaće javnosti, ali je, na drugoj strani, izazivao oduševljenje kod onih socijalističkih grupa u inostranstvu koje su se protivile ratu: kod ruskih boljševika, bugarskih „tesnih" socijalista, nemačke frakcije oko Roze Luksemburg i Karla Libknehta i dr.

Antiratni stav srpskih socijaldemokrata proizilazio je iz marksističke ocene ovog rata i sagledavanja njegovog imperijalističkog karaktera. U pismu koje je Dušan Popović, jedan od vođa partije posle Tucovićeve smrti, pisao iz zaraćene Srbije 1915. godine, vidi se koli-

\footnotetext{
${ }^{25}$ Isto, Reprint izdanje, Zemun, 2011. godine, str. 38.

${ }^{26}$ Isto, str. 25.

${ }^{27}$ Isto, str. 53-54.
} 
ko su oni „robovali” marksističkom tumačenju ovog rata, posebno insistiranju na njegovom imperijalističkom karakteru: „Za nas je bilo jasno kao sunce, što se tiče odnosa između Srbije i Austro-Ugarske, da se naša zemlja nalazi u odbrambenom položaju (...) u svojoj suštini, Srbija štiti svoj život, svoju nezavisnost, koje je Austrija neprestano ugrožavala i do Sarajevskog atentata. I ako bi ma gde socijaldemokrati uopšte imali pravo da glasaju za rat, to bi na prvom mestu bilo u Srbiji”. ${ }^{28}$ I Lenjin je isticao da, ukoliko je neka država imala prava da se brani, onda je to bila Srbija i da je utoliko značajniji stav SSDP-a. ${ }^{29}$ lako je Roza Luksemburg takođe naglašavala da se, formalno gledano, u slučaju Srbije može govoriti o „legitimnoj nacionalnoj odbrani”, nije zaboravljala da napomene da je Srbija samo pion u svetskoj politici i da „iza srpskog nacionalizma leži ruski imperijalizam”. ${ }^{30}$

Zašto je SSDP odbila da prihvati i podrži ovaj rat, iako je on za Srbiju bio odbrambeni? Borba srpskih socijalista protiv rata bila je povezana, pre svega, sa borbom protiv politike vezivanja srpske vlade za velike sile, odnosno za jedan od imperijalističkih blokova (Centralnih sila i sila Antante) koji su pripremali međusobni obračun. Isticali su da su oba bloka predstavljala neprijatelje balkanskih naroda. Dušan Popović je pisao: „Za nas je ipak bila odlučujuća činjenica, da je rat između Srbije i Austrije bio samo mali deo, samo uvertira evropskog, svetskog rata, a da poslednji, prema našem najdubljem ubeđenju, nije mogao imati nikakav drugi do izrazito imperijalistički, kapitalistički karakter. Iz tog razloga mi smo smatrali da je naša imperativna dužnost, da kao deo velike socijalističke i proleterske Internacionale svom odlučnošću istupimo protiv rata". Tadašnje stanje međunarodnih odnosa, u kojem se jasno naslućivao sukob između dva „imperijalistička” bloka, nije dozvoljavalo da se austrougarski napad na Srbiju posmatra sa specifičnog, lokalnog stanovišta male zemlje koja je napadnuta od velike imperijalističke sile. To je potvrdio i Dušan Popović u jednom od svojih članaka iz 1918. godine, u kojem je pisao da je partija na to pitanje gledala „ne sa srpskog, već sa internacionalnog i proleterskog stanovišta”, iskazujući spremnost da u „času ovih velikih tragičnih iskušenja” nacionalni interes podredi „višim interesima međunarodnim i čovečanskim”. Ako to ne učini, tvrdio je Popović, ona ne može biti socijalistička, već nacionalistička. ${ }^{3}$

Organizaciono razbijena, sa velikim ljudskim gubicima, od kojih su najtragičnije doživljene smrti Dimitrija Tucovića (novembra 1914) ${ }^{32}$ i Dušana Popovića (1918), rad partije se sveo na međusobne prepirke i pojedine lične inicijative njenih članova. Tokom 1916.

\footnotetext{
${ }^{28}$ Pismo je objavljeno u Parizu, u listu „Naše slovo”. navedeno prema: S. Dimitrijević, Socijalistički radnički pokret u Srbiji 1870-1918, str. 229.

${ }^{29}$ V. I. Lenjin, „Oportunitam i slom Druge internacionale”. Brošura je štampana na nemačkom jeziku u časopisu Vorbote (Preteča), br. 1, januar 1916.

${ }^{30}$ https://www.scribd.com/document/299590025. Rosa Luxemburg, The Junius Pamphlet: The Crisis in the German Social Democracy, u: Rosa Luxemburg Speaks, New York 1970, str. 309. Navedeno prema: Dragan Plavšić, The First World War and the Balkan Federation (Introduction), u: The Balkan Socialist Tradition..., str. 226; Srpskohrvatski prevod u: Rosa Luxemburg, Izabrani spisi, Naprijed, Zagreb 1974.

${ }^{31}$ Navedeno prema: S. Dimitrijević, Socijalistički radnički pokret u Srbiji 1870-1918, str. 231.

${ }^{32}$ Dimitrije Tucović, dugogodišnji partijski sekretar i ideolog, tvorac antiratne politike SSDP-a poginuo je već na početku rata (20. novembra 1914). O razlozima za odlazak na front Tucović je pisao: „Ovaj rat je nametnut Srbiji sa strane imperijalističkih sila Austro-Ugarske i Nemačke. Braneći Srbiju, mi branimo našu narodnu samostalnost i sve naše političke slobode i demokratske tekovine u njoj. Od ishoda ovog rata zavisi i budućnost socijalizma u Srbiji. I zato ja kao i svi ugledni članovi pokreta, sposobni za borbu, moramo biti u boračkim jedinicama. Zbog toga niti želim niti bih primio ma kakvo sklonjeno mesto" (Nikola Popović, Dimitrije Tucović: njegov život i rad, Beograd, 2014, str. 105-106).
} 
godine među srpskom socijalističkom emigracijom, uglavnom u Francuskoj, ali i na Solunskom frontu, počeo je da se javlja socijalpatriotizam. Pokušaj revizije antiratne politike SSDP-a nastao je, s jedne strane, pod uticajem savezničke socijaldemokratske štampe i delovanjem agenata srpske vlade, partijskih opozicionara i bivših partijskih članova, a, s druge strane, pod utiskom okupacije Srbije i razvoja ratnih događaja koji su deo članstva, daleko od uticaja Popovića, Lapčevića i Kaclerovića, naveli da oslobođenje i ujedinjenje Južnih Slovena počnu prihvatati kao politički zahtev srpskih socijalista. To ih je približilo ratnim ciljevima saveznika i srpske vlade. Oslobođenje Južnih Slovena u Austrougarskoj i njihovo ujedinjenje sa Srbijom bilo je prihvatljivo srpskim socijalistima u emigraciji, jer se i SSDP od početka zalagala za pravo svih naroda na samoopredeljenje, pa su ga i ovi prihvatili kao sopstveni politički program.

Nastojanje Dušana Popovića tokom 1918. godine da antiratnu politiku SSDP-a ponovo proširi na ostale evropske socijaldemokratske partije završilo je njenim definitivnim političkim razlazom sa partijama Druge internacionale - onima koje su u ratu pružile podršku vladajućim strukturama u svojim zemljama. Antiratna i antisocijalpatriotska akcija u poslednjoj godini rata dovela je do približavanja srpskih socijalista pozicijama boljševika, čak i do neposredne podrške koju su neki među njima pružali Oktobarskoj revoluciji. Pogibija Dimitrija Tucovića (1914) i smrt Dušana Popovića (1918) bile su veliki udarac za posleratnu partijsku orijentaciju SSDP-a. Ipak, ona je odigrala značajnu ulogu u ujedinjenju radničkog pokreta Jugoslavije, bila je revolucionarni zametak iz kojeg će izrasti Komunistička partija Jugoslavije između dva svetska rata. ${ }^{33}$

Prvi svetski rat učinio je kraj jedinstvenom frontu evropske levice. Od momenta kada su mnogi socijaldemokrati širom Evrope zamenili svoj internacionalizam učešćem u vojnim poduhvatima svojih država, temelji Druge internacionale bili su ozbiljno poljuljani. Oktobarska revolucija 1917. godine samo je još više ubrzala započetu polarizaciju u međunarodnom radničkom pokretu. Treća internacionala, osnovana marta 1919. godine pod neposrednim uticajem sovjetske boljševičke partije, inicirala je potpuni raskid sa idejnim nasleđem Druge internacionale. Na njenom Trećem kongresu (u julu i avgustu 1920) Lenjin je predstavio svoj čuveni dokument, poznat kao „21 uslov”, na način koji je zapadnoevropsku socijaldemokratsku levicu trajno udaljio od tek formiranih komunističkih partija u Evropi. Od njih se tražilo da izbace sve reformiste i centrumaše iz svojih redova, da prihvate unutarpartijsku disciplinu, podrže bezrezervno Sovjetsku republiku, iskažu spremnost za ilegalni rad i prihvate za sebe komunistički naziv kao obavezujući.

Istovremeno će u skoro svim predratnim socijaldemokratskim partijama u Evropi doći do rascepa na dve struje - komunističku i socijaldemokratsku. Unutar Srpske socijaldemokratske partije sukob dve koncepcije imaće konačni epilog na Vukovarskom kongresu Socijalističke radničke partije Jugoslavije (komunista), juna 1920. godine. SRPJ je formirana aprila 1919. godine na Kongresu ujedinjenja, kome su prisustvovali predstavnici le-

\footnotetext{
${ }^{33}$ Godine 1915. održana je konferencija balkanskih socijaldemokrata u Bukureštu (druga po redu, a prva u ratnim uslovima) na kojoj je zaključeno da treba osnovati Revolucionarnu balkansku socijaldemokratsku radničku federaciju, sastavljenu od grupa (iz Rumunije, Bugarske, Srbije i Grčke) koje su se protivile učešću u Prvom svetskom ratu. To je bio poslednji formalni pokušaj balkanskih socijaldemokrata da ostanu dosledni u svom antiratnom stavu. Jedan od najpoznatijih učesnika ove konferencije bio je Georgi Dimitrov iz Bugarske radničke socijaldemokratske partije, budući komunistički lider i funkcioner Kominterne. Međutim, realizaciju ovih zaključaka osujetile su vlade pomenutih država.
} 
Iskustva i pouke iz prošlosti

vih krila predratnih socijaldemokratskih stranaka iz Srbije, Hrvatske, Bosne i Slovenije, a koji su prihvatili boljševičko opredeljenje u pogledu klasne borbe protiv buržoazije i revolucionarnog rušenja kapitalističkog poretka. Rascep na revolucionarne komuniste i reformističke socijaldemokrate događao se tada u svim radničkim partijama u Evropi, pa i u redovima Socijalističke radničke partije Jugoslavije, na Vukovarskom kongresu, kada su socijaldemokrati napustili ovu partiju koja će tom prilikom promeniti ime u - Komunističku partiju Jugoslavije (KPJ). Odlazak Dragiše Lapčevića, koji je posle rata bio najpoznatije ime srpske socijaldemokratije iz KPJ označio je kraj jedne epohe u razvoju socijalističke misli u Srbiji i početak nove, komunističke epohe, koja će obeležiti veći deo 20. veka.

\section{KPJ i nacionalno pitanje u Jugoslaviji između dva svetska rata}

Oktobarska revolucija u Rusiji 1917. godine dala je podsticaj novim idejama o uspostavljanju federacije na Balkanu, a njen promoter ovoga puta bila je Kominterna - Treća internacionala (Komunistička internacionala), osnovana u Moskvi 1919. godine. Ona je okupljala komunističke partije u Evropi i objedinjavala njihov rad između dva svetska rata. Kominterna je prihvatila stvaranje balkanske komunističke federacije, kao okosnicu svoje politike na Balkanu. Već na Drugom kongresu (u junu 1920) promovisala je ideju federacije kao najbolji prelazni oblik državnog uređenja višenacionalnih država koje se nalaze „na putu od kapitalizma ka komunizmu", pa će je i KPJ prihvatiti kao ključno načelo u vođenju nacionalne politike, kako u fazi kada je (do sredine tridesetih godina) zagovarala razbijanje Jugoslavije, tako i onda kada je prihvatila jugoslovensku državu, uz uslov da ona bude preuređena na federativnom principu.

Kominterna je od početka imala krajnje negativan stav prema Jugoslaviji. Na nju je gledala kao na „produkt imperijalističkog rata” i veštačku versajsku tvorevinu, koja je stvorena primenom oružane sile, a ne voljom jugoslovenskih naroda za oslobođenjem od tuđinske vlasti i ujedinjenjem. ${ }^{34}$ Taj stav će vrlo brzo uticati na KPJ da, bez obzira na prvobitni pozitivan odnos prema ujedinjenju jugoslovenskih naroda, i sama radikalizuje svoju politiku prema Jugoslaviji. Rezolucija Petog kongresa Kominterne (iz jula 1924) o nacionalnom pitanju u Jugoslaviji definisala je ovu državu kao višenacionalnu zajednicu u kojoj je oko $70 \%$ stanovništva, koje ne pripada srpskom narodu, „više ili manje potčinjeno režimu nacionalnog ugnjetavanja” i „politici denacionalizacije” od strane srpske buržoazije. Teorija o „jedinstvenom troimenom narodu Srba, Hrvata i Slovenaca” predstavljala je, kako se tumačilo u ovoj rezoluciji, samo „masku velikosrpskog imperijalizma”.

\footnotetext{
${ }^{34}$ Iza ovakvog antijugoslovenskog stava stajala je, navodno, „namera imperijalističkih sila da Balkan pretvore u bazu za kontrarevolucionarni rat protiv Sovjetskog Saveza". Formiranje Jugoslavije (Kraljevine SHS) protumačeno je neposredno kao imperijalistički akt: „Već samim stvaranjem države SHS, stvorene su mnogobrojne i duboke suprotnosti unutar te države, koje neizbežno vode u susret novome ratu i koje se mogu rešiti samo slomom te državne tvorevine. Dok su pri pretvaranju predratne Srbije u sadašnju državu SHS pobednički imperijalisti Antante ostavili više stotina hiljada Slovenaca i Hrvata pod jarmom italijanskog imperijalizma, oni su stavili pod vlast velikosrpske buržoazije ne samo Slovence, Hrvate i do rata nezavisne Crnogorce i ostavili pod njenom vlašću 1913. godine osvojeni najveći deo Makedonije, nego su joj priklonili i znatna albanska, bugarska i mađarska područja. Na takav način, kao sastavni deo svetskog imperijalističkog sistema, Senžermenskim, Trijanonskim i Nejskim mirovnim ugovorima stvoreni novi sistem nacionalnog ugnjetavanja u državi SHS, stvorio je i nove suprotnosti između države SHS i njenih suseda" (Istorijski arhiv KPJ, knj. II, Zbornik dokumenata, Beograd, 1950, str. 182; Rezoluciji sa Petog kongresa Kominterne, juli 1924. godine).
} 
Po mišljenju stratega Kominterne, nacionalno pitanje u Jugoslaviji nije bilo ustavno pitanje, samim tim ni pitanje revizije Vidovdanskog ustava, već prvenstveno „pitanje borbe nacionalno ugnjetenog stanovništva” i „pravo njegovog nacionalnog samoopredeljenja”, a zatim „pitanje revolucionarne borbe radnih masa u Jugoslaviji”. U skladu sa usvojenom doktrinom o nacionalnom pitanju kao sredstvu revolucije, na jugoslovenskom primeru borba protiv nacionalnog ugnjetavanja, za pravo naroda na samoopredeljenje do otcepljenja i za „radničko-seljačku vlast” morala je biti povezana sa opštom borbom protiv „reakcionarne velikosrpske buržoazije", protiv monarhije i protiv Vidovdanskog ustava. ${ }^{35}$ Od jugoslovenskih komunista se, kao rešenje nacionalnog pitanja, zahtevala borba za izdvajanje Hrvatske, Slovenije i Makedonije iz sastava Jugoslavije i njihovo pretvaranje u nezavisne republike, kao i „podržavanje prava na otcepljenje Mađara i borbe albanskog naroda na nezavisnost”. $^{36} \mathrm{U}$ formulisanju nacionalnog pitanja i rešavanju sudbine Jugoslavije kao države, Kominterna je prednjačila u odnosu na KPJ, pa je pomenutom Rezolucijom (iz jula 1924) praktično poništena odluka Treće zemaljske konferencije KPJ, od decembra 1923. godine, kao nedovoljno oštra i nedovoljno dosledna u odnosu na stavove Kominterne. ${ }^{37}$

Već naredne, 1925. godine, Kominterna je (Rezolucijom o jugoslovenskom pitanju koju je doneo Peti prošireni plenum Izvršnog komiteta Kominterne) ponovo zahtevala od KPJ da intenzivira borbu „proletarijata i seljačkih masa” u Jugoslaviji protiv glavnog neprijatelja vladajuće velikosrpske buržoazije i njene militarističke monarhije: „Činjenica da tek proleterska revolucija i obrazovanje saveza sovjetskih republika može da da čvrste temelje za pot-

${ }^{35}$ Antijugoslovenska politika Kominterne i floskule o „reakcionarnoj velikosrpskoj buržoaziji”, „velikosrpskoj hegemoniji” i dr, mogu se objasniti i činjenicom da je Jugoslavija, zahvaljujući nepomirljivoj antisovjetskoj poziciji vodećih srpskih političkih krugova, posebno zbog prihvatanja i organizovanja belogardejske emigracije između dva rata, ocenjena kao opasnost za SSSR i za perspektivu boljševičke revolucije u jugoistočnoj Evropi. Zato je Jugoslaviju trebalo uništiti.

${ }^{36}$ Istorijski arhiv KPJ, str. 420-421; Rezolucija sa Petog kongreda Kominterne, juli 1924. godine.

${ }^{37} \mathrm{U}$ Rezoluciji sa Treće zemaljske konferencije KPJ isticalo se da je osnovni uzrok zaoštravanja nacionalnih suprotnosti u zemlji - zavojevačka kolonijalna politika srpske buržoazije još pre Prvog svetskog rata u Makedoniji i protiv Albanije, kao i njena hegemonistička politika u Državi SHS; da je „proces sve dubljeg nacionalnog razjedinjavanja već toliko napredovao da se država Srba, Hrvata i Slovenaca ne može smatrati kao homogena nacionalna država s nešto nacionalnih manjina, nego kao država u kojoj vladajuća klasa jedne (srpske) nacije ugnjetava ostale nacije” (Isto, str. 69-70). Time je KPJ utemeljila formulu o „velikosrpskom hegemonizmu”, ne samo kao bitnu odrednicu jugoslovenske države i nacionalnog pitanja u njoj između dva rata, već se na nju uporno pozivala i tokom Drugog svetskog rata u dokumentima i javnim nastupima njenih funkcionera. U „Rezoluciji o makedonskom i trakijskom pitanju” srpska buržoazija je optužena da „sprovodi u Makedoniji najoštriji teroristički režim, uništava ili goni na iseljavanje svesni deo bugarskog, turskog i arnautskog stanovništva i dovodi naseljenike iz drugih oblasti Jugoslavije na njihovo mesto, da potlačuje sve nesrpske narodnosti” (Isto, str. 76; Pod "nesrpskim narodnostima” nije se mislilo na Makedonce, koje će KPJ kao posebnu naciju promovisati tek u Drugom svetskom ratu, 1943. godine, već na Bugare, Turke i Atnaute).

„Rezoluciji o nacionalnom pitanju”, doneta na ovoj konferenciji, ističe pravo na samooprederljenje i otcepljenje kao načelnu osnovu za rešenje nacionalnog pitanja: „KPJ priznaje svakom narodu pravo na suverenost u određivanju svojih odnosa, dakle i pravo na slobodno otcepljenje i obrazovanje svoje posebne države, odnosno na priključenje svojoj nacionalnoj državi". (Isto, str. 70). Međutim, u daljem tumačenju ovog stava, partija je ostavila sebi odrešene ruke za pragmatično opredeljivanje prema ovom načelu, odnosno mogućnost da se u praksi ono ne prizna i ne sprovede, u skladu sa drugim i „višim” državnim i nacionalnim razlozima. Ako bi se ovaj stav KPJ primenio na pitanju albanske nacionalne manjine, onda bi ona imala pravo da se „priključi svojoj nacionalnoj državi”, tj. Albaniji. Ali, da li će to partija u praksi zaista i ostvariti, zavisilo je od mnogih drugih okolnosti koje bi mogle pokazati da je takva „amputacija” samo nova forma nacionalnog ugnjetavanja ili su „teškoće otcepljenja” nepremostive. U ovim stavovima primetna je nedorečenost, kao i određena doza kolebljivosti u rukovodstvu KPJ. 
puno rešenje nacionalnog pitanja, ne sme da odvede ni jednog komunistu dotle da izgubi iz vida veoma važno političko značenje koje imaju nacionalni sukobi i borbe za vreme kapitalizma, naročito u jednoj mnogonacionalnoj državi kao što je Jugoslavija. Naprotiv, komunisti moraju umeti da koncentrišu svu revolucionarnu energiju koja se krije u pokretima ugnjetenih nacija u svrhu rušenja diktature velikosrpske buržoazije i ubrzanja proleterske revolucije”. Ponavljajući da je dužnost jugoslovenskih komunista da „brane i potpomažu” ostvarenje prava „potlačenih nacija” na samoopredeljenje do otcepljenja, podsećala je da je krajnji cilj - federativno uređenje radničko-seljačkih republika na Balkanu. ${ }^{38}$

Priliku da se između dva svetska rata, u konkurenciji sa građanskim strankama, nametne kao relevantan faktor u uzavrelom političkom miljeu novostvorene države (Kraljevine SHS), u uslovima potpune nacionalne i konfesionalne podeljenosti, pretećih separatizama, političke, ekonomske i socijalne nekonzistentnosti državnog prostora, Komunistička partija Jugoslavije nalazila je u programskoj koncepciji koja je, uz socijalno, apostrofirala i nacionalno kao dominantno pitanje u Jugoslaviji između dva rata. U uslovima ilegalnog rada, od 1921. godine, KPJ je svoju političku strategiju definisala uglavnom putem zvaničnih partijskih dokumenata, na kongresima i zemaljskim konferencijama održavanim u inostranstvu, da bi krajem tridesetih godina, sa prelaskom rukovodstva Partije u zemlju i početkom rata u Evropi (1939), a naročito posle aprilskog rata u Jugoslaviji i okupacije zemlje 1941. godine, njena aktivnost počela izlaziti iz okvira teorijskog pristupa programskim načelima i u taktičkom smislu poprimati oblike konkretne borbe za ostvarenje revolucionarnih ciljeva. Nacionalnu politiku jugoslovenskih komunista i njihov odnos prema unutrašnjem uređenju jugoslovenske države u međuratnom periodu karakterisale su tri faze: početkom dvadesetih godina KPJ je prihvatila unitarnu državu, ${ }^{39}$ da bi se od 1923. do 1935. godine zalagala za razbijanje Jugoslavije i formiranje nezavisnih država (sa nacionalnim predznakom) na njenom tlu. U godinama uspona nacionalizma u Evropi i jugoslovenski komunisti su sredinom 30-ih godina, pod uticajem Moskve, prihvatili jugoslovensku državu za koju će se boriti i u ratu 1941-1945. godine, opredelivši se za federativnu formulu države bez vodećeg naroda. ${ }^{40}$

Kao disciplinovana članica Kominterne, KPJ se između dva svetska rata oslanjala na stavove i dosledno izvršavala direktive komunističke centrale u Moskvi. Uticaj sovjetskog mentora posebno će se odraziti u periodu od 1923. do 1935. godine, u kojem su jugoslovenski komunisti vodili politiku razbijanja sopstvene države, smatrajući je poligonom zapadnih sila za imperijalistički rat protiv SSSR-a, bastionom antisovjetizma na Balkanu, veštač-

\footnotetext{
${ }^{38}$ Isto, str. 433-436.

${ }^{39}$ Program KPJ usvojen na Drugom (Vukovarskom) kongresu juna 1920. godine, kao krajnji politički cilj partije, proklamovao je stvaranje „Sovjetske Republike Jugoslavije” i njeno stupanje u „bratski savez sa svim susednim narodima radi vaspostavljanja sovjetske federacije balkansko-podunavskih zemalja, koja će biti sastavni deo međunarodne federacije sovjetskih republika. Ova međunarodna federacija sovjetskih republika će stvoriti opšti Savez i trajan mir među narodima" (Istorijski arhiv KPJ, str. 35). U tom trenutku KPJ je, doduše, prihvatala Jugoslaviju kao istorijski opravdanu i zakonitu državu troplemenog naroda (Srba, Hrvata i Slovenaca), da bi nešto kasnije iz Moskve, preko Balkanske komunističke federacije (1919. godine „Balkanska radnička socijaldemokratska federacija" čije je osnivanje dogovoreno na konferenciji balkanskih socijaldemokrata 1915. u Bukureštu, pretvorena je u „Balkansku komunističku federaciju”) u kojoj su glavnu reč vodili bugarski komunisti Vasil Kolarov i Georgi Dimitrov, usledio i prvi podsticaj za reviziju njenog stava prema Jugoslaviji.

${ }^{40}$ Mirjana Zorić, Srbi u nacionalnoj politici KPJ između dva rata i u Drugom svetskom ratu, Svarog, časopis za društvene i prirodne nauke, Nezavisni univerzitet Banja Luka, br. 1, 2010, str. 108.
} 
kom versajskom tvorevinom koja brani poredak ustanovljen pariskim mirovnim ugovorima posle Prvog svetskog rata, ${ }^{41}$ sa srpskom nacijom i njenom buržoazijom kao vladajućom, koja nacionalno ugnjetava i ekonomski iscrpljuje nesrpske nacije u Jugoslaviji. ${ }^{42}$

U duhu Kominterninih direktiva iz 1924/1925. godine, KPJ se na svom Trećem kongresu (održanom 1926. u Beču) definitivno odredila prema Jugoslaviji kao „mnogonacionalnoj državi u kojoj se srpska nacija javlja kao vladajuća”, sa „imperijalističkim režimom vladajuće srpske buržoazije” zasnovanom na politici „nacionalnog ugnjetavanja i ekonomskog iscrpljivanja nesrpskih nacija”. Naglašavajući opravdanost „silnog nezadovoljstva" nesrpskih nacija i pružajući podršku formiranju nacionalnih pokreta u Hrvatskoj, Sloveniji, Makedoniji, Vojvodini i Crnoj Gori, KPJ je sebe videla kao jedinu partiju koja se „najdoslednije bori za pravo samoopredeljenja do otcepljenja od današnje države”, a u perspektivi za formiranje Federacije radničko-seljačkih republika na Balkanu". ${ }^{3}$

U „Rezoluciji o nacionalnom pitanju” sa Plenuma CK KPJ, održanog 25. novembra 1924. godine, otišlo se i korak dalje. Prvi put je decidirano okrivljena čitava srpska nacija, a ne samo njena buržoazija i vladajuća klasa, kao ugnjetačka. ${ }^{44}$ Rezolucija je bila izričita u primeni antijugoslovenske formule: „Zbog svega toga dužnost je Partije da sa organizacijama radnih masa ugnjetenih nacija vodi zajedničke otvorene borbe za pravo na otcepljenje, odnosno da pomaže pokrete ugnjetenih nacija u cilju formiranja nezavisnih država kako Hrvatske, Slovenije, Makedonije i Crne Gore, tako i radi oslobođenja Albanaca" ${ }^{45}$ Ovde se prvi put kao zadatak KPJ formuliše izričito i borba za „oslobođenje Albanaca”, tj. za njihovo otcepljenje od Jugoslavije i ujedinjenje, razume se u perspektivi jedne nove, sovjetske albanske republike.

$\mathrm{Na}$ Četvrtom kongresu u Drezdenu, oktobra 1928. godine, KPJ je i zvanično promovisala politiku razbijanja Jugoslavije, zalažući se za stvaranje nezavisnih država na njenim ruševinama - Hrvatske, Slovenije, Crne Gore, Makedonije, ali i „oslobađanje” i predaju Kosova i Metohije Albaniji, a severne Bačke Mađarskoj. Na osnovu analize unutrašnje političke situacije za koju se smatralo da vodi ka pojačanju nacionalnih sukoba, zaoštravanju državne krize i sve otvorenijim zahtevima „potlačenih naroda Jugoslavije” „za nacionalnom nezavisnošću, za otcepljenjem", kongres je doneo odluku o stvaranju nezavisnih država Hrvatske, Slovenije, Makedonije („nezavisne i ujedinjene”) i Crne Gore, „nezavisne i ujedinjene Albanije" (koja bi obuhvatala i delove Jugoslavije naseljene Albancima) i odluku o pravu na otcepljenje mađarske nacionalne manjine u severnoj Vojvodini. Položaj Srbije i njena prava, kao ni ranije, nisu definisani, osim dužnosti KPJ u Srbiji da se bori protiv nacionalnog ugnjetavanja, jer je u njoj baza „,hegemonističkog režima”, i za pravo na otcepljenje ugnjetenih nacija. Kao i na Trećem (1926), i na ovom kongresu KPJ je rešenje nacionalnog pitanja ne samo jugoslovenskih, već i balkanskih naroda u celini videla u stvaranju balkanske federacije radničko-seljačkih republika. ${ }^{46}$

\footnotetext{
${ }^{41}$ Ljubodrag Dimić, Istorija srpske državnosti, Srbija i Jugoslavija, knj. III, Beograd, 2001, str. 262.

${ }^{42}$ Istorijski arhiv KPJ, str. 111; Rezolucija sa trećeg kongresa KPJ o nacionalnom pitanju, održanog u Beču juna 1926. godine.

${ }^{43}$ Isto, str. 110-112.

${ }^{44}$ Isto, str. 333.

${ }^{45}$ Isto, str. 339.

${ }^{46}$ Isto, str. 162-166; Rezolucija Četvrtog kongresa KPJ o privrednom i političkom položaju Jugoslavije i o zadacima KPJ.
} 
Apostrofirajući svoju podršku „borbi radničke klase, seljaštva i ugnjetenih nacija, pre svega protiv glavnog neprijatelja - hegemonističke buržoazije i njene vojne monarhije", KPJ je otvoreno zagovarala pravo „ugnjetenih” nacija na samoopredeljenje do otcepljenja i pravo na oružani ustanak protiv nacionalnog ugnjetavanja, pri čemu je nudila „sistematsku pomoć pokretima ugnjetenih nacija”. „Pomoć” komunista secesionističkim pokretima u Kraljevini nije ostala samo na deklarativnoj podršci, već se manifestovala i u nekritičkim stavovima prema nekim antirežimskim organizacijama i otvorenoj podršci terorističkim akcijama hrvatskih i makedonskih ekstremnih nacionalista koji su pokazali najveći stepen odricanja jugoslovenske države. Izvršni komitet Kominterne je, maja 1930. godine, od KPJ tražio da pristupi stvaranju „borbenih sporazuma” sa svima koji se opredeljuju za oružani obračun protiv „srpske (monarhističke) diktature”, pri čemu se u prvom redu mislilo na Hrvatsku stranku prava (ustaše). Za komunističku omladinu, na primer, ustaška organizacija je bila „revolucionarna”, jer se borila protiv fašističke diktature, zbog toga što je želela samostalnu Hrvatsku i što je sklona da se za svoje ciljeve izbori oružanim putem.

Preko svog lista „Proleter” KPJ je pozdravljala aktivnost ustaša u zemlji, njihove organizacije tretirala kao nacionalno-revolucionarne i zahtevala od svog članstva da im pruži pomoć. Vrhunac takve politike izražavao je proglas koji je KPJ uputila iz Beča u vreme ustaškog „ličkog ustanka” (1932), u kojem se obraćala „cijelom Hrvatskom narodu” tražeći podršku ustaškoj akciji. ${ }^{47}$ Pozvani su čak i „radnici i seljaci Srbije” da „svim snagama” pomognu borbu ustaša i naroda u Lici i Hrvatskoj. "Proleter” je 26. septembra 1932. godine obaveštavao da "mestimice radnici i seljaci odlaze u šumu i započinju ustašku borbu protiv državnih vlasti”. I u nizu drugih natpisa, pod istu zastavu pozivani su svi u borbu protiv „krvavog kralja Aleksandra poslednjeg". ${ }^{9}$ Tridesetih godina vrata za saradnju bila su otvorena za sve one koji su se deklarisali kao saveznici komunista iz „ugnjetenih nacija” i koji su bili spremni da prihvate njihov nacionalni program. Legitimitet im je davao često ponavljani Staljinov stav da su Hrvati „ugnjeteni narod”, zbog čega je 1932. godine traženo razbijanje jugoslovenske države i formiranje nezavisne Hrvatske u granicama gde Hrvati „predstavljaju etničku većinu". Srbima je, takođe, priznavano pravo na samoopredeljenje - tamo gde oni predstavljaju većinski narod, ali se pri tome imalo u vidu samo uže područje Srbije. ${ }^{50}$

Kao i u drugim delovima Jugoslavije, gde je od 1928. godine dolazilo do saradnje komunista sa fašističkim grupama koje su nazivali „nacional-revolucionarnim grupama”, jugoslovenski komunisti su, takođe, računali na saradnju i sa albanskim ekstremnim nacionalistima. U Rezoluciji sa Četvrtog kongresa KPJ u Drezdenu 1928. godine Partija je izražavala solidarnost „revolucionarnih radnika i seljaka” ostalih nacija Jugoslavije, pre svega Srbije, s „makedonskim nacionalno-revolucionarnim pokretom” (VMRO-om) i „al-

\footnotetext{
${ }^{47}$ Branislav Gligorijević, Kominterna, jugoslovensko i srpsko pitanje, Beograd, 1992, str. 260.

${ }^{48}$ Navedeno prema: Desanka Pešić, Jugoslovenski komunisti i nacionalno pitanje 1919-1935, Beograd, 1983, str. 258.

${ }^{49}$ Navedeno prema: Veselim Đuretić, Upotreba Rusije i zapada, Obmane saveznika zarad velikohrvatske politike, Beograd, 1997, str. 49.

${ }^{50}$ Isto, str. 49-50; „Delujući kao miljenici nove Rusije”, piše Đuretić, „hrvatski razbijači Jugoslavije 30-tih godina delovali su u tesnoj vezi s 'makedonstvujuščim”. Njihova žrtva bio je kralj Aleksandar 1934. Ova saradnja je u Staroj Srbiji i Makedoniji donosila diverzije, ubistva, masovne nerede, najviše u sredinama naseljenim solunskim dobrovoljcima. Divljanja komita postajala su svakodnevna. Vešti manipulanti su to koristili da nekonstituisano društvo preko socijalne sfere odnosa antagonizuju prema Srbiji..." (Isto, str. 50)
} 
banskim nacionalno-revolucionarnim pokretom” koji je predstavljao Kosovski komitet ${ }^{51}$ i pozvala radničku klasu da „svestrano pomaže borbu za nezavisnu i ujedinjenu Makedoniju i borbu ugnjetenog albanskog naroda za nezavisnu i ujedinjenu Albaniju". ${ }^{2}$

Princip nacionalnog samoopredeljenja i otcepljenja u partijskim dokumentima oslanjao se na kriterijume koji nisu afirmisali podelu među narodima, već prema teritorijama koje ti narodi u većini ili samo delimično nastanjuju, a koje kao posebne države nisu do tada postojale i čije su državne granice bile nepoznate. Potpuno je ignorisana i činjenica da su se u jugoslovenskom slučaju nacionalni interesi pojedinih naroda često ukrštali na jednom nacionalnom prostoru, a ponuđena teritorijalna rešenja bila su u suprotnosti sa interesima srpskog naroda. U proklamovanoj Velikoj Hrvatskoj, koja bi obuhvatala i znatan deo Bosne, Hercegovine i Vojvodine, u Velikoj Albaniji, sa Kosovom i Metohijom, ostao bi u znatnom broju srpski narod u kompaktnim celinama, bez prava na nacionalno samoopredeljenje i konstituisanje svoje nacionalne države. U navedenim slučajevima koncept KPJ (preuzet od Kominterne) koji je polazio od prava „istorijskih" pokrajina na otcepljenje oslanjao se na princip istorijskog i državnog prava, ${ }^{53}$ ali je u teorijskom smislu ostao nedorečen i nedosledan, posebno kada je u pitanju bilo definisanje statusa Srbije i državno-pravnog okvira kojim bi srpski narod bio obuhvaćen.

Komunistička partija Jugoslavije je do sredine 30 -ih godina istrajavala na programskim načelima u nacionalnoj politici, ali bez jasno uobličenog i definisanog koncepta o oblastima koje je trebalo da dobiju status nezavisnih država. Tako je u 1929. godini jedna od parola za rešenje nacionalnog pitanja bila - „slobodne i samostalne radničko-seljačke republike Hrvatska, Slovenija, Srbija, Makedonija, Crna Gora, BiH i Vojvodina"; u 1930. godini - „samostalne, nezavisne radničko-seljačke republike Hrvatska, Srbija, Slovenija, Makedonija, Crna Gora”; u 1931. godini - „samostalne i nezavisne Hrvatska, Slovenija, Crna Gora, Makedonija...”; u 1933. godini ponovo se pominju „radničko-seljačke republike" Srbija, Hrvatska, Slovenija, Makedonija i Crna Gora, dok se u slučaju Vojvodine „priznavalo pravo otcepljenja mađarskih krajeva u severnoj Vojvodini”. lako je Vojvodina tretirana kao oblast koja se „po svom ekonomskom, socijalnom i političkom položaju znatno razlikuje od ostalih zemalja u Jugoslaviji”, pitanje njenog statusa je svedeno na pitanje prava mađarske nacionalne manjine na otcepljenje, odnosno prepuštanje ovog dela jugoslovenske državne teritorije (severne Vojvodine) Mađarskoj. ${ }^{54}$

U partijskim dokumentima, do sredine tridesetih godina, upotreba pojma Srbije, za razliku (manje više) od drugih jugoslovenskih zemalja, nije apostrofirala i njen istorijski, državno-pravni, nacionalni i teritorijalni subjektivitet (koji objektivno u periodu Kraljevine SHS, odnosno Jugoslavije nije ni egzistirao). Uprkos svojoj državotvornoj tradiciji i statusu nezavisne države koju je 1918. godine ugradila u temelje Jugoslavije, Srbija je u međuratnom razdoblju figurirala samo kao geografska odrednica, bez funkcionalnog politič-

\footnotetext{
${ }^{51}$ Osim fašističkih sila, velikoalbanska iredentistička aktivnost između dva svetska rata imala je snažnu podršku i Kominterne, u fazi njene politike razbijanja jugoslovenske države kao tvorevine „versajskog sistema”. Već početkom 1920. godine albanski „Kosovski komitet” povezao se sa Kominternom, a u decembru iste godine Bajram Curi, jedan od prvaka ove organizacije, posetio je sovjetskog poslanika u Beču i sa njim raspravljao o pitanju Kosova i Metohije (Nicolas C. Pano, The People's Republik Albania, Baltimore, 1968, str. 27).

${ }^{52}$ Istorijski arhiv KPJ, knj. II, str. 163.

${ }^{53}$ B. Gligorijević, Kominterna.., str. 282-288.

${ }^{54}$ D. Pešić, Jugoslovenski komunisti i nacionalno pitanje..., str. 259.
} 
kog individualiteta i administrativnog oblikovanja kao posebne i celovite jedinice u sastavu Kraljevine. Administrativnim preuređenjem Kraljevine Jugoslavije 1929. godine (na 9 banovina), teritorija Srbije (pojam koji je u međuratnom periodu podrazumevao Srbiju pre balkanskih ratova, uvećanu Kosovom, Metohijom i Sandžakom) bila je podeljena na pet banovina (Moravsku, Vardarsku, Zetsku, Drinsku i Dunavsku) i posebnu celinu - Upravu grada Beograda sa Pančevom i Zemunom. Sa idejama o preuređenju Jugoslavije na federativnoj osnovi od 1932. godine, zaoštravanjem srpsko-hrvatskih odnosa 1932-1939. i stvaranjem Banovine Hrvatske, aktueliziran je i pojam Srbije u nacionalnom i državnopravnom smislu, a sa početkom rešavanja hrvatskog pitanja (1939) otvaralo se u punoj meri i srpsko pitanje. Međutim, izbijanje rata u kojem će se od 1941. godine naći i Jugoslavija prekinuće proces započet 1939. godine koji je vodio unutrašnjem preuređenju države u pravcu stvaranja jugoslovenske federacije.

Uporedo sa opcijama građanskih političkih krugova o preuređenju Jugoslavije, 1936. godine pojavio se i prvi komunistički projekat ${ }^{55}$ o federativnoj reorganizaciji države i stvaranju sedam (federalnih) jedinica - Srbije, Hrvatske, Slovenije, Makedonije, Crne Gore, Bosne i Hercegovine i Vojvodine. Nacionalna koncepcija federativne reorganizacije koju su zagovarali komunisti razlikovala se od nacionalne politike srpske građanske opozicije. Dok su komunisti Crnogorcima i Makedoncima priznavali pravo na nacionalnu samobitnost, odnosno izjednačavali ih u nacionalnim pravima sa Srbima, Hrvatima i Slovencima, a Bosni, Hercegovini i Vojvodini priznavali pravo na regionalnu samostalnost u federalnoj državi, srpska nacionalna politika koju je zagovarala građanska politička elita u procesu jugoslovenske reorganizacije između dva rata računala je na Srbiju, „Južnu Srbiju” (Makedoniju), Vojvodinu, Crnu Goru, Bosnu i Hercegovinu kao jednu srpski jedinicu koju bi činile navedene „srpske zemlje”. ${ }^{56}$

Lagani zaokret u stavovima prema jugoslovenskoj državnoj zajednici kao ključnom pitanju svoje nacionalne politike koji je KPJ započela u toku 1934. godine najavio je odricanje od višegodišnje borbe protiv versajskih ugovornih rešenja i Jugoslavije kao njihove veštačke tvorevine, a time i napuštanje politike koja je jedini put za rešenje jugoslovenskog nacionalnog pitanja videla u raspadu jugoslovenske države. Kao i u prethodnom periodu, usvajanje nove taktike u nacionalnoj politici inicirala je Kominterna, a uslovile su je prvenstveno interesi Sovjetskog Saveza, kao i međunarodni faktori (radikalnim promenama na evropskoj političkoj sceni uzrokovanim ekspanzijom fašizma). Proces pregrupisavanja snaga na međunarodnom planu, podstaknut pobedom nacista u Nemačkoj 1933. godine, i pojačanom pretnjom nemačkog fašizma SSSR-u rezultirao je Staljinovom promenom spoljne politike, izlaskom SSSR-a iz izolacije, njegovim prijemom u Društvo naroda, približavanjem Francuskoj i Čehoslovačkoj, promenom stava prema Maloj Antanti, osudom atentata na kralja Aleksandra i politikom Narodnog fronta, koja je proklamovala saradnju sa svim demokratskim snagama u borbi protiv zajedničkog neprijatelja. Platforma Narodnog fronta inaugurisana na Sedmom kongresu Kominterne 1935. godine bila je obavezujuća za sve njene sekcije, sam tim i KPJ.

U skladu sa narodnofrontovskom taktikom i novom međunarodnom pozicijom Sovjetskog Saveza, Kominterna je korigovala i svoju politiku prema Jugoslaviji. U vreme uspona nacionalsocijalizma u Nemačkoj, jugoslovenska država na Balkanu bila je mnogo ko-

\footnotetext{
${ }^{55}$ Reč je o pismu Veselina Masleše mesnom komitetu KPJ Beograda od 2. novembra 1936, naslovljenom kao "Titovo pismo za Srbiju” (J.B.Tito, Sabrana djela, tom 3, str. 32-38)

${ }^{56}$ Branko Petranović, Jugoslovensko iskustvo srpske nacionalne integracije, Beograd, 1993, str. 12.
} 
risnija Sovjetskom Savezu (kao moguća brana potencijalnoj agresiji ka jugu Evrope) od niza slabih „mikro” država koje bi nastale na njenim temeljima. Angažovanjem „neoficijelnih" ličnosti (poput istoričara Roberta Siton Votsona) i Velika Britanija preuzima aktivnu ulogu u reorganizaciji jugoslovenske države na (nacionalnom) federativnom principu, ${ }^{57}$ koji je bio u funkciji „slabljenja srpske prevlasti” i rešavanja hrvatskog pitanja. ${ }^{58}$

Prilagođavanje jugoslovenskih komunista novoj taktici narodnog fronta i odricanje od politike razbijanja Jugoslavije odvijalo se, međutim, „sa puno odstupnica i taktičkih manevara”: od prećutnog neporicanja jugoslovenske države na Četvrtoj zemaljskoj konferenciji, decembra 1934, preko uzdržanog prihvatanja te države na Splitskom plenumu juna 1935, do njene afirmacije, mada uslovne, u toku 1935. godine. U „Odluci Politbiroa CK KPJ o zadacima Partije posle VII kongresa Kominterne” definisani su načelni stavovi po pitanju budućeg uređenja Jugoslavije: „Ostajući pri svom principijelnom gledištu samoopredeljenja naroda sa pravom na otcepljenje, komunisti uzimaju u obzir sadašnju međunarodnu situaciju i pri uslovu uništenja nacionalne neravnopravnosti, maksimalnih garancija slobode hrvatskog i drugih naroda i slobodnog pristanka tih naroda, ne izjašnjavaju se za otcepljenje tih naroda od današnje državne zajednice - Jugoslavije". Dakle, prihvatanje Jugoslavije kao državnog okvira za rešenje nacionalnog pitanja nije bilo bezuslovno, niti je značilo potpuno napuštanje principa koje je zagovarala KPJ u prethodnom periodu. ${ }^{59}$

Promenu politike prema Jugoslaviji komunističko rukovodstvo je objašnjavalo spoljnim činiocima i unutrašnjim političkim razlozima. Među spoljne faktore navodila se najpre „opasnost od nemačkog i italijanskog fašizma po svetski mir, njihova težnja za revizijom versajskih granica novim (imperijalističkim) ratom i pripremama napada na SSSR”, kao i činjenica da „Francuska i njeni saveznici više ne predstavljaju onu silu koja želi da izazove novi imperijalistički rat”, naprotiv, oni su „mada možda privremeno, zainteresovani za očuvanje mira”. Sklapanje pakta o uzajamnoj pomoći između Francuske i SSSR-a komunisti su smatrali jednom od garancija stabilnosti Evrope. ${ }^{60} \mathrm{Na}$ unutrašnjem planu evidentna je promena taktike KPJ prema građanskoj političkoj opoziciji u pitanjima koja su se ticala unutrašnjeg preuređenja Jugoslavije. Ovu promenu naročito je karakterisalo približavanje Hrvatskoj seljačkoj stranci i Mačekovom konceptu očuvanja „državne zajednice u današnjim granicama pri uslovu slobode hrvatskog naroda”. ${ }^{61}$ Apostrofiranje i apsolutizacija Mačekovih političkih stavova najavljivali su početak približavanja KPJ federalističkom konceptu HSS-a, odnosno njegovoj varijanti rešavanja hrvatskog nacionalnog pitanja i „udvaranja” nacionalno homogenom (kompaktnom) i politički jedinstvenom hrvatskom pokretu koji je, nasuprot srpskom nacionalno razuđenom i politički razbijenom pokretu, postepeno osvajao jugoslovenski politički prostor tridesetih godina.

Od 1935. godine federacija se kao rešenje jugoslovenskog nacionalnog pitanja sve više ističe i u zvaničnim dokumentima KPJ. Cinjenica je da je komunistički federalistički koncept u bitnim elementima predstavljao kopiju hrvatskih građanskih ideja koje će 1939. godine biti funkcionalizovane sporazumom Cvetković-Maček o stvaranju Banovine Hrvat-

\footnotetext{
${ }^{57}$ Britancima je najbliži bio projekt od pet federalnih jedinica: Slovenija, Hrvatska sa Dalmacijom i Dibrovnikom, Bosna i Hercegovina, Vojvodina, Srbija sa autonomnom južnom Srbijom i Crnom Gorom (Lj. Dimić, Srbija i Jugoslavija, knj. III, str. 175).

${ }^{58}$ B. Petranović, Jugoslovensko iskustvo, str. 44.

${ }^{59}$ Istorijski arhiv KPJ, knj. II, str. 369.

${ }^{60}$ Navedeno prema: D. Pešić, Jugoslovenski komunisti i nacionalno pitanje..., str. 272.

${ }^{61}$ Isto.
} 
Iskustva i pouke iz prošlosti

ske. $^{62}$ „Titovo pismo za Srbiju” iz novembra 1936. godine u svom zahtevu za federativnom „rekonstrukcijom" države u osnovi podseća na Mačekov koncept iz 1932. godine kojim je on tražio da „Hrvatska, Srbija, Crna Gora, Vojvodina, Makedonija i Bosna i Hercegovina sačine federalni ugovor o životu Jugoslaviji”. " 63 oba slučaja, kao i u svim kasnijim komunističkim i hrvatskim (građanskim) varijantama, kako tvrdi Veselin Đuretić, „federalizovane su nacionalno projektovane samo srpske istorijske ili regionalne celine i etnički delovi ovog naroda koji su putem preveravanja bili delimično odvojeni od Srpstva i njemu na određeni način suprotstavljeni”. ${ }^{64}$

Koncept komunističke federacije, teorijski uobličen kroz partijske dokumente pre rata, podrazumevao je savez slobodnih naroda u demokratskoj federativnoj državi (Jugoslaviji), izgrađenoj na osnovu slobodnog sporazuma ravnopravnih naroda, a shodno načelu neograničenog prava na nacionalno samoopredeljenje. ${ }^{65} \mathrm{U}$ pitanju je bila, dakle, federativna formula države bez vodećeg naroda. Iskustva avnojevske (druge) Jugoslavije, čiji su temelji udareni u Drugom svetskom ratu i njena kasnija (posleratna) federativna događanja, pokazaće u kojoj meri je ona bila „proizvod” slobodnog sporazuma ravnopravnih naroda.

\section{Balkanska (jugoslovensko-bugarska) federacija 1943-1948. godine - neostvareni projekti}

U vreme dok se pripremalo Drugo zasedanje AVNOJ-a, u jesen 1943. godine, na slobodnu teritoriju u zapadnoj Bosni stigao je bugarski komunista Šterju Atanasov (poznatiji pod pseudonimom Viktor), koji je vođstvu Narodnooslobodilačkog pokreta Jugoslavije preneo preporuku Georgi Dimitrova da se na zasedanju AVNOJ-a razmotri i pitanje stvaranja južnoslovenske federacije. ${ }^{66}$ lako je na sednici CK KPJ od 16. do 18. oktobra 1943. u Jajcu odlučeno da NKOJ posebnom deklaracijom istakne „Federaciju Južnih Slovena” kao sopstvenu programsku parolu, od toga se ipak odustalo, jer je Broz procenio da se nisu stekli uslovi za formalno uobličavanje jedne tako krupne odluke, pre svega zbog međunarodnih okolnosti. Nije teško pretpostaviti da bi protiv takve federacije bili Britanci (od septembra 1943. pri Vrhovnom štabu NOVJ nalazila se njihova vojna misija na čelu sa brigadnim generalom Ficrojem Maklejnom), mada u tom trenutku ona nije odgovarala ni rukovodstvu nove Jugoslavije. Tek je u proglasu kojim se CK KPJ u javnosti oglasio povodom 26-godišnjice Oktobarske revolucije navedeno, doduše samo formalno, da se stvaraju uslovi „za ostvarenje davnog sna najboljih sinova južnoslovenskih naroda - bratske federativne zajednice južnoslovenskih naroda od Trsta do Crnog Mora".

\footnotetext{
${ }^{62}$ „Hrvatski komunisti sakriveni iza jugoslovenske zavese”, pisao je Veselin Đuretić, „svojim teritorijalnim megalomanstvom, nastavljali su staru i krčili put novoj građanskoj hrvatskoj politici, u prvom redu Hrvatskoj seljačkoj stranci. Federalne jedinice koje su oni pominjali i one koje je pominjao Maček podudarale su se. Bile su iste one koje će nekoliko godina kasnije ući u sastav Banovine Hrvatske..." (V. Đuretić, Upotreba Rusije i zapada, str. 56).

${ }^{63}$ Isto, str. 60.

${ }^{64}$ Isto, str. 94.

${ }^{65}$ Proleter, br. 2, februar 1937, str. 11-12; proglas CK KPJ iz januara 1937. godine.

${ }^{66} \mathrm{Ne}$ zna se da li je Dimitrov raspolagao Staljinovom formalnom saglasnosnošću da uputi ovakvu jednu poruku, ali je logično da je u uslovima centralizacije sovjetske spoljne politike i vojnih poslova u Staljinovim rukama, on morao biti konsultovan. Dimitrov se posle raspuštanja Kominterne nalazio na čelu Odeljenja za informacije CK SKP(b), nastavljajući da obavlja poslove raspuštenog „„̌taba svetske revolucije” (Izvršnog komiteta Kominterne).
} 
Nekako $u$ isto vreme neuspešno se okončala i inicijativa Svetozara Vukmanovića Tempa oko formiranja Balkanskog štaba. Naime, Vukmanović je, u svojstvu specijalnog delegata CK KPJ, od leta 1943. godine boravio na jugu Srbije i u Makedoniji, sa zadatkom da radi na intenziviranju, povezivanju i koordinaciji narodnooslobodilačkog pokreta Jugoslavije, Grčke i Albanije. Boraveći u Makedoniji, Albaniji i Grčkoj, Tempo je uspostavio kontakte sa njihovim partizanima, partijskim i vojnim predstavnicima i razgovarao u vezi sa saradnjom i razvijanjem zajedničkih akcija protiv okupatora, iz čega će vrlo brzo poteći i inicijativa oko formiranja Balkanskog štaba.

Na sastanku predstavnika komunističkih partija Grčke, Jugoslavije i Albanije, održanom 20. juna 1943. godine na teritoriji Albanije, istaknuta je potreba za obrazovanjem jedinstvene komande „balkanskih narodnooslobodilačkih vojski” u vidu Balkanskog štaba i potreba za razvijanjem vojne i političke saradnje, pri čemu se imalo u vidu stvaranje Balkanske konfederacije posle rata. Ove zaključke potpisali su delegati Komunističke partije Jugoslavije (Svetozar Vukmanović Tempo), Komunističke partije Grčke i Komunističke partije Albanije (Enver Hodža). Karakteristično je da se u zaključcima sa ovog sastanka, pored vojne dimenzije, ističe i potreba za političkom saradnjom, koja bi obezbedila buduće funkcionisanje „narodne demokratske vlasti u svim balkanskim zemljama”. ${ }^{67}$

Ideju o stvaranju Balkanskog štaba doveo je u pitanje sam Josip Broz u jesen 1943. godine, kada je preko Štaba 2. korpusa NOVJ (koji se nalazio u Crnoj Gori) savetovao Vukmanoviću da odustane od ove inicijative, ,jer je to sad politički nepravilno”. Preko Glavnog štaba NOV Makedonije poručio mu je da je obrazovanje Balkanskog štaba „iz osnova pogrešno, jer svi međunarodni razlozi govore protiv toga". Balkanski štab, pisalo je u Brozovoj direktivi, „umanjio bi značaj našeg pokreta, našeg Vrhovnog štaba i AVNOJ-a, a pred inostranstvom bi izgledalo da se stvara neka balkanska 'internacionala' što bi reakcija svih boja mogla samo da iskoristi za izolaciju oslobodilačkog pokreta". Koliko je uticaj brigadira Ficroja Maklejna, šefa britanske vojne misije bio evidentan, govori i Brozovo upozorenje da se mora voditi računa o međunarodnom položaju Jugoslavije: „....Mi moramo strogo voditi računa o Jugoslaviji kao državi koja je postojala i još je priznata u inostranstvu kao takva, čuvajući se da formalno ne prekoračimo te okvire i našim parolama i raznim frazama ne koristimo reakcionarnim klikama koje pokrete balkanskih naroda u balkanskim državama hoće da prikažu kao neki balkanski boljševizam, boljševizaciju Balkana i tome slično (...) Mesto toga, pravilno je razvijati snage narodnooslobodilačkog pokreta u svim zemljama Balkana, politički sarađivati i menjati iskustva sa bratskim partijama, pomažući ih da i one u svom radu iskoriste sva neiscrpna bogatstva naše borbe, kako političke (prirode), tako i vojničke".

U poruci od 9. oktobra 1943. godine Broz kritikuje Vukmanovića što se oduševio idejom balkanskog štaba, naglašavajući da bi „svako stvaranje u sadašnjoj situaciji nekog zajedničkog štaba bilo pogrešno, pa dapače i štetno (...) Mi imamo naš Vrhovni štab za čitavu Jugoslaviju koji može da pruži u svakom pogledu pomoć, kako bugarskim, tako i grčkim partizanima. Ovo je narodno-oslobodilačka borba jugoslovenskih naroda, grčkog naroda, a to treba da bude i bugarskog naroda. Prema tome, u okviru svojih nacionalnih granica moraju da postoje rukovodeći vojni centri koji mogu sarađivati na savezničkoj osnovi, bilo putem vojnih predstavnika, ili političkih predstavnika, radi koordinacije opera-

${ }^{67}$ Branko Petranović, Balkanska federacija 1943-1948, Beograd, 1991, str. 56-62. 
cija i prenošenja iskustava iz te borbe. Jugoslavija u svakom pogledu zauzima rukovodeću ulogu na Balkanu, kako po svojoj vojnoj moći Narodnooslobodilačke armije, tako i po iskustvu stvaranja narodne vlasti. Prema tome, i po našem mišljenju, a isto tako i po mišljenju 'Djede' (konspirativno ime za Kominternu - prim. autor), mi treba da budemo centar za balkanske zemlje, kako u vojničkom, tako i u političkom pogledu".

U skladu sa novim okolnostima, vezanim za ukidanje Kominterne, dolazak britanske vojne misije u Vrhovni štab (septembra 1943) i početne obrise nove britanske politike kompromisa u Jugoslaviji, Broz je očigledno bio prinuđen da stornira jedan deo započetih inicijativa Svetozara Vukmanovića u trouglu Jugoslavije, Grčke i Albanije. Time se, svakako, Jugoslavija nije odricala svoje rukovodeće uloge na Balkanu za koju se, u odnosu na ostale balkanske zemlje, izborila zahvaljujući oslobodilačkoj akciji koju je vodila u periodu od 1941. do 1943. godine. Svojim institucionalnim „utapanjem” u vojno-političke okvire Balkanskog štaba, pretpostavljalo se da bi njen narodnooslobodilački pokret izgubio tu prednost. Obustavljajući Vukmanovićevu inicijativu oko stvaranja Balkanskog štaba, Broz je delegatu Centralnog komiteta KPJ jasno stavio do znanja da je njegov zadatak u Makedoniji da ostvari što čvršću vezu sa Bugarskom i Grčkom, a naročito sa Bugarskom, iz vojnih i političkih razloga, kako „nas tamo događaji ne bi pretekli i neki drugi preuzeo inicijativu u svoje ruke...” Time je, u ovoj fazi (od leta do jeseni 1943), ideja o stvaranju Balkanskog štaba kao potencijalnog vojno-političkog jezgra buduće balkanske federacije ili konfederacije bila obustavljena. ${ }^{68}$

Do približavanja Jugoslavije i Bugarske došlo je oktobra 1944. godine, nakon pada fašističkog režima u Bugarskoj i formiranja nove bugarske vlade Otečestvenog (Otadžbinskog) fronta na čelu sa komunistima, čija je delegacija 5. oktobra 1944. u Krajovi (Rumunija) zaključila sporazum sa Josipom Brozom o vojnoj saradnji bugarske vojske i NOVJ u oslobađanju istočnih delova Jugoslavije. Ovaj sporazum, na kojem je insistirao sam Staljin radi rehabilitacije novog, komunističkog režima u Bugarskoj, otvoriće novu stranicu u odnosima dveju susednih država i dovešće ubrzo do prvih razgovora o formiranju jugoslovensko-bugarske federacije po završetku rata. O ovom pitanju raspravljalo se već $u$ jesen iste godine između bugarske delegacije koja je predstavljala Otadžbinski front i Nacionalnog komiteta oslobođenja Jugoslavije. Povodom tih razgovora Georgi Dimitrov je, 23. novembra 1944, u svom Dnevniku zapisao: „... tada smo se dogovorili o pripremi za sklapanje saveza između Bugarske i Jugoslavije, imajući u vidu perspektivu stvaranja zajedničke federacije Južnih Slovena".

U bugarskom predlogu Sporazuma o savezu, koji su izradila dvojica lidera bugarske Komunističke partije G. Dimitrov i V. Kolarov, pisalo je: „Ovaj savez će biti važan korak za povezivanje svih balkanskih naroda, radi zaštite od bilo kakve agresije i radi obezbeđivanja sigurnosti i prosperiteta na Balkanu". ${ }^{9}$ Prilikom prijema Edvarda Kardelja, Ivana Šubašića i Stanoja Simića u Moskvi, 22. novembra 1944. godine, Staljin je, u prisustvu Molotova, insistirao na stvaranju bugarsko-jugoslovenske federacije. Simić je izveštavao da je Staljin smatrao da „sa Bugarskom treba ubrzati proces federativne zajednice. Kad narod hoće”, govorio je tom prilikom, „to niko ne može da spreči”."

\footnotetext{
${ }^{68}$ Isto, str. 65-68.

${ }^{69}$ Navedeno prema: Danijela D. Popović, Rezolucija Informbiroa i 1948. godina u očima ruskih istoričara i istraživača, feljton u listu Dan, od 8. do 18. marta 2008. godine.

${ }^{70}$ Navedeno prema: B. Petranović, Balkanska federacija 1943-1948, str. 126.
} 
Razgovori o obrazovanju federacije između Jugoslavije i Bugarske otpočeli su u Sofiji, decembra 1944. godine. S jugoslovenske strane vodio ih je Edvard Kardelj. Već na samom početku došlo je do nesuglasica između jugoslovenskih i bugarskih predstavnika po pitanju oblika ujedinjenja. Bugari su predlagali da se zajednička država organizuje po principu konfederacije koju bi činile Jugoslavija (jugoslovenska federacija) i Bugarska, insistirajući, dakle, na njenom dualnom konceptu. Jugoslovenski predstavnici su se zalagali za pluralistički koncept, u skladu sa federativnim ustrojstvom Jugoslavije, ustanovljenim na Drugom zasedanju AVNOJ-a u Jajcu, novembra 1943. godine, da Bugarska uđe u sastav Jugoslavije sa istim pravima kao i njene republike i narodi. Tito je bio izričito protiv saveza u kojem bi Bugarska bila „ravna” čitavoj Jugoslaviji. Tim povodom ovlastio je Josipa Smodlaku da sačini jugoslovensku verziju nacrta ugovora o ujedinjenju dveju država, po kojem bi nova federacija pretpostavljala pluralističku formu šest jugoslovenskih federalnih jedinica sa Bugarskom kao sedmom jedinicom. ${ }^{71}$

Kako je već prvi projekat sporazuma koji je ponudila Jugoslavija za bugarsku stranu bio neprihvatljiv, sastavljen je novi nacrt 25 . decembra 1944, koji se značajno razlikovao od prethodnog. Nova verzija predstavljala je više sporazum o uzajamnoj pomoći nego o federaciji. Ona je predviđala da dve zemlje vode samostalno svoju politiku, ali u tesnoj saradnji i jedinstvu, da ukazuju jedna drugoj svu pomoć i podršku do pobede nad zajedničkim neprijateljem, ispunjavajući u isto vreme svoje obaveze iz sporazuma sa Ujedinjenim nacijama. $U$ interesu ekonomskog razvoja dveju zemalja bilo je predviđeno zaključivanje carinskog saveza koji bi se oslanjao na odgovarajuće trgovinske, ekonomske, železničke, transportne, valutne i druge sporazume, kao i ukidanje pasoškog sistema između dveju država. Jugoslavija i Bugarska su se obavezale da jedna drugoj pružaju podršku i pomoć u svemu što bi se ticalo izgradnje političke vlasti u dvema državama. Tačka 4. predviđala je da ponuđena verzija sporazuma ugovornim stranama bude osnova u cilju „preduzimanja svih mera za što brže ujedinjenje Bugarske i država koje ulaze u sastav federativne Jugoslavije, u jedinstvenu federativnu državu". Tačkom 5 . obe strane su priznale pravo makedonskom narodu na puno samoopredeljenje. Bugarska se obavezala da će prihvatiti da se deo Makedonije koji je od 1913. godine pripadao Bugarskoj (Pirinska Makedonija) prisajedini ujedinjenoj makedonskoj državi koja će, opet, u svojstvu ravnopravnog člana, ući u sastav federacije južno-slovenskih naroda, a jugoslovenska strana se obavezala da će oni delovi bugarske teritorije koji su pripali Jugoslaviji prema ugovoru u Nejiu 1919. godine (bosilegradski srez sa Dimitrovgradom i caribrodski srez - prim. autor) biti vraćeni Bugarskoj. ${ }^{72}$

Petog januara 1945. godine u Beogradu je izrađen još jedan (treći po redu) nacrt ugovora o ujedinjenju DFJ (Demokratske Federativne Jugoslavije) i Bugarske u jednu federativnu državu. Očigledno je da su predstavnici obeju država (NKOJ i bugarska vlada) tokom razgovora u Beogradu vodili računa i o Staljinovim intencijama da se do jugoslovensko-bugarske federacije što pre dođe. ${ }^{73}$ Ovaj nacrt predviđao je da se Demokratska Republika Jugoslavija i Bugarska ujedine u federativnu državu koja be se sastojala od sedam federalnih jedinica,

\footnotetext{
${ }^{71}$ Isto, str. 122-123.

${ }^{72}$ Isto, str. 126-128.

${ }^{73}$ Doduše, Staljinov stav je više išao na ruku bugarskom predlogu o dualnom uređenju buduće federacije; Staljin nije želeo „upijanje” Bugarske u jugoslovensku federaciju, već njeno ujedinjenje s Jugoslavijom (D.D. Popović, Rezolucija Informbiroa i 1948. godina u očima ruskih istoričara i istraživača).
} 
šest jugoslovenskih i sedme koju bi činila Bugarska. U pitanju je bila izrazito pluralistička koncepcija na kojoj je insistirala jugoslovenska vlada i ona je za Jugoslaviju predstavljala najpovoljniju formulu. Federativna država bi imala jedno zajedničko narodno predstavništvo i zajedničku federalnu vladu, a u ekonomskoj sferi predstavlja bi jedinstveno carinsko područje. U zajedničke spadali su i vojni poslovi, vođenje spoljne politike i carina, kao i svi oni poslovi koji bi u budućem ustavu federativne države trebalo da budu označeni kao zajednički.

Obrazovana je i zajednička bugarsko-jugoslovenska komisija sa sedištem u Beogradu (pod nazivom - Komisija južnoslovenskog jedinstva), sa zadatkom da izradi nacrt Ustava zajedničke države. Komisija je bila sastavljena od predstavnika Bugarske i šest federalnih jedinica DFJ, koje su imenovale bugarska i jugoslovenska vlada. S obzirom na vanredne, ratne okolnosti, kao i na položaj Bugarske koja je do početka septembra 1944. godine bila članica sila Osovine, dogovoreno je da Jugoslavija i Bugarska do završetka rata zadrže svoje vlade, s tim da spoljne i vojne poslove vode sporazumno, po dogovoru dveju vlada. Ugovorom je dogovoreno da se ukinu političke i carinske granice između Bugarske i Jugoslavije, da obe države odmah po usvajanju ugovora raspolažu zajedničkim diplomatskim i konzularnim predstavnicima u inostranstvu, da deo Makedonije koji je od 1913. godine pripadao Bugarskoj bude prisajedinjen vardarskoj Makedoniji, kao federalnoj jedinici demokratske federativne Jugoslavije, $s$ tim što bi u isto vreme Bugarskoj bili vraćeni oni delovi teritorije koji su bili ustupljeni Kraljevini SHS na osnovu ugovora u Nejiu 1919. godine. Pitanje naknade štete koju je Jugoslavija do 9. septembra 1944. godine pretrpela od bugarskog okupacionog režima trebalo je rešiti sporazumno „u duhu bratskog dogovora”. Planirano je da ugovor stupi na snagu čim ga odobre ovlašćeni predstavnici Jugoslavije i Bugarske - AVNOJ i vlada Otečestvenog fronta. ${ }^{74}$

Dok se u Beogradu raspravljalo o nacrtu ovog ugovora, 11. januara 1945. godine šef jugoslovenske delegacije u SSSR-u (Andrija Hebrang) iz Moskve je javio Josipu Brozu da je razgovarao sa „Starim” (Staljinom) i da „Sovjeti mnoga politička pitanja postavljaju drugačije od Jugoslovena". Naime, Staljin je savetovao da se sa Bugarima zaključi Pakt o savezu i uzajamnoj pomoći na 10 - 20 godina, koji bi bio prvi korak ka ujedinjenju. Insistirao je na dualnom uređenju buduće federacije, da Jugoslavija i Bugarska sačine konfederaciju. Staljin je sugerisao da se sporazumi s Bugarskom i Albanijom ne objavljuju dok Jugoslavija ne bude imala međunarodno priznatu vladu. Zahtevao je da obe strane budu obazrive u spoljnopolitičkim pitanjima, jer je glavni zadatak da se ojačaju postignute pobede i „izbegne ono što bi većim zahtevima prema susednim zemljama moglo izazvati rđave odnose sa njima ili čak sukob". Iz pisma Andrije Hebranga, jugoslovenskog poverenika za trgovinu i industriju, ovlašćenog da vodi političke i ekonomske pregovore i sklapa ugovore sa sovjetskom vladom, uočljivo je da je Staljin nameravao da preinači karakter sporazuma koji je postignut između Jugoslavije i Bugarske, sugerišući Pakt o savezu i uzajamnoj pomoći, a ne federaciju dveju susednih država. Istovremeno, ostao je dosledan dualističkoj formuli bliskoj Bugarima, označavajući buduću državnu zajednicu kao konfederaciju. ${ }^{75}$

Sovjetski lider bio je svestan međunarodnih teškoća koje bi pratile zaključenje južnoslovenske federacije, odnosno konfederacije, s obzirom na status vojno poražene Bugarske i činjenicu da je rat još uvek bio u toku. Pitanje jugoslovensko-bugarske federacije

\footnotetext{
${ }^{74}$ Navedeno prema: B. Petranović, Balkanska federacija 1943-1948, str. 128-130.

${ }^{75}$ Isto, str. 130.
} 
sve se više komplikovalo na međunarodnom planu. Tito je krajem januara 1945. dobio telegram od Molotova u kojem se tražilo da Jugosloveni i Bugari pošalju u Moskvu svoje delegate na pregovore. Tokom razgovora koji su tim povodom vođeni, na zahtev sovjetske strane odlučeno je ipak da se (na određeno vreme) odustane od stvaranja jugoslovensko-bugarske federacije i da se potpiše samo Ugovor o prijateljstvu, savezu i uzajamnoj pomoći između dveju balkanskih zemalja. Sovjeti su svoju saglasnost na takav ugovor dali već 27. januara 1945. godine.

Nacrt Ugovora o prijateljstvu, savezu i uzajamnoj pomoći temeljio se na tesnoj političkoj, vojnoj i ekonomskoj saradnji Jugoslavije i Bugarske; formula „bratskog saveza” nije izostala ni u ovoj varijanti ugovora. Sem što su se obe vlade saglasile da jedna drugoj ukazuju svaku pomoć do potpunog poraza Nemačke, one su se obavezale da ne ulaze ni u kakav savez i ne zaključuju bilo kakav ugovor ili sporazum s drugim državama, ukoliko bi takvi akti bili usmereni protiv Jugoslavije ili Bugarske. Obe strane ugovornice pozdravile su odluku AVNOJ-a kojom je makedonskom narodu priznata nacionalna individualnost, a Makedoniji data ravnopravnost kao federalnoj jedinici Jugoslavije. Bugarska vlada se obavezala da sa jugoslovenskom vladom uredi pitanja koja su se ticala dela Makedonije koji je Bukureškim ugovorom iz 1913. godine pripao Bugarskoj. Jugoslovenska vlada je, kao i u ranijim varijantama ugovora, izjavila da će u sporazumu sa vladom Bugarske rešiti pitanja onih bugarskih teritorija koje su ugovorom u Nejiu iz 1919. godine pripale Jugoslaviji. Bugarska je, takođe, priznala štetu koju je nanela Srbiji i Makedoniji tokom okupacije i prisustvom svojih trupa na njihovoj teritoriji. Obavezala se da će putem posebnog sporazuma sa jugoslovenskom vladom dati Jugoslaviji neophodno pravno zadovoljenje. Tako su se, pod uticajem međunarodnih faktora, od ideja o stvaranju južnoslovenske federacije, ambicije dveju zemalja svele na zaključenje Ugovora o prijateljstvu, savezu i uzajamnoj pomoći. Deo Ugovora činilo je i poverljivo pismo koje je trebalo da potpišu ministri predstavnici Jugoslavije i Bugarske, a koje je sadržavalo izjavu da ugovor predstavlja samo „osnovicu i prvi korak za dalje razvijanje tesnih bratskih odnosa njihovih naroda” i da je glavni cilj sadašnjeg zbliženja „ostvarenje u što kraćem vremenu federacije južnoslovenskih naroda".

Međunarodne smetnje formiranju južnoslovenske federacije otpočele su već krajem 1944. godine. U Memorandumu koji je 5. decembra 1944. godine potpisao Antoni Idn, ministar spoljnih poslova Velike Britanije, istaknuto je da njegova zemlja ne može da prihvati jugoslovensko-bugarsku federaciju, jer bi stvaranje ovakve države poremetilo ravnotežu snaga među balkanskim državama, a pre svega izolovalo Grčku i ugrozilo njen položaj kao balkanske države. Idn je smatrao da bi Bugarska, kao saveznica Nemačke u Drugom svetskom ratu, ulaskom u balkansku federaciju zapravo izbegla posledice svoje ratne politike, na taj način „što bi svoj identitet pomešala s identitetom jedne od država članica UN".

Na Krimskoj konferenciji u februaru 1945. godine ponovo je tretirano pitanje jugoslovensko-bugarskog ugovora o savezu. U Protokolu o radu Krimske konferencije od 11. februara pod tačkom 10. (o jugoslovensko-bugarskim odnosima) izričito je stajalo: „... između ministara inostranih poslova došlo je do razmene gledišta po pitanju poželjnosti jednog jugoslovensko-bugarskog ugovora o savezu. Bilo je postavljeno pitanje da li se jednoj državi koja se još nalazi pod režimom primirja može dozvoliti da zaključi jedan

\footnotetext{
${ }^{76}$ Isto, str. $130-132$.
} 
ugovor sa drugom državom". Britanska delegacija je predložila da se sa dnevnog reda definitivno skine pitanje jugoslovensko-bugarskih odnosa, dok se sovjetsko rukovodstvo zalagalo da se sačeka da Bugarska potpiše mirovni ugovor (u Parizu).

U februaru 1945. godine zapadne sile su iskazale krajnje negativan stav prema bugarsko-jugoslovenskoj federaciji zbog straha da bi moglo doći do teritorijalnih pretenzija prema Grčkoj, vezanih za Egejsku Makedoniju. Sjedinjene Države su razmatrale čak i mogućnost primene vojne sile prema Jugoslaviji, u slučaju da ona pošalje svoje jedinice u Grčku. U to vreme Jugoslavija je doživljavana kao velika pretnja politici Zapada, jer je, osim podrške grčkim partizanima, ${ }^{77}$ imala teritorijalne pretenzije prema Trstu i delovima Julijske krajine, a i pitanje Istre nije bilo do kraja razrešeno. Grčka je bila od posebne važnosti Britancima koji su nastojali po svaku cenu da je zadrže kao svoju interesnu sferu, slično Sovjetima koji će to učiniti sa zemljama istočne Evrope.

Vladimir Popović, predstavnik NKOJ-a i CK KPJ u Bugarskoj, obavestio je 4. februara 1945. godine Josipa Broza da su Britanci 26. januara zvanično saopštili bugarskoj vladi da ne bi odobrili federaciju ili konfederaciju samo između Bugarske i Jugoslavije, već da su spremni, navodno, da podrže ulazak i Albanije, Grčke i Turske u takvu državnu zajednicu. Protivtežu južnoslovenskoj federaciji pod protektoratom Sovjetskog Saveza Britanci su, zapravo, nalazili u balkanskoj federaciji, odnosno konfederaciji koja ne bi imala samo slovenski karakter i koja bi uključila i ostale neslovenske države na Balkanu: Albaniju, Grčku i Tursku. Takvu koncepciju Britanci su imali još od 1942. godine, kada se raspravljalo o stvaranju balkanske unije između Kraljevine Jugoslavije i Grčke, koja bi u perspektivi otvorila vrata za ulazak u Uniju i drugim balkanskim državama.

Za vladu Sjedinjenih Američkih Država bilo je, takođe, „neprikladno da Bugarska, kao bivši satelit Osovine, i još uvek neprijateljska država, stupi u pregovore za zaključenje ugovora ili drugih međunarodnih sporazuma u periodu kad se nalazila pod kontrolom Savezničke komisije, ukoliko nije takav sporazum posebno podržan od strane tri glavna saveznika i drugih zainteresovanih vlada". Stejt Department je obavestio sovjetsku i britansku vladu da neće blagonaklono gledati na zaključenje takvog pakta. I pre nego što je Memorandum američke vlade o zaključenju Ugovora o savezu i uzajamnoj pomoći između Jugoslavije i Bugarske od 3. marta 1945. godine uručen otpravniku poslova DFJ u Vašingtonu, a on ga prosledio Ivanu Šubašiću, predsedniku kraljevske vlade koji će samo nekoliko dana kasnije postati ministar inostranih poslova u privremenoj vladi DFJ, Sovjeti su bili svesni međunarodnih implikacija koje bi mogle nastupiti ukoliko bi se po pitanju jugoslovensko-bugarske federacije ignorisala upozorenja zapadnih saveznika.

\footnotetext{
${ }^{77}$ Važan faktor u planovima o uspostavljanju balkanske federacije bio je i grčki građanski rat. Naime, grčki komunisti (Komunistička stranka Grčke i njen vojni ogranak „Elas” - Grčka narodnooslobodilačka vojska) organizovali su na severu zemlje tzv. Privremenu demokratsku vladu, koju su podržavali jugoslovenski, bugarski i albanski komunisti. Grčki partizani mogli su se u slučaju potrebe prebacivati preko granice u Albaniju i Makedoniju. Sjedinjene Države i Velika Britanija osudile su formiranje te vlade i pomoć koju su joj pružale druge balkanske države. I Staljin se protivio podršci koju su jugoslovenski, bugarski i albanski komunisti pružali grčkim komunistima, priklanjajući se razoružanju „Elasa”, u skladu sa ranijim dogovorom sa zapadnim saveznicima da Grčka pripadne njihovoj sferi uticaja. U svemu tome, primetan je bio Titov uticaj na vojnu organizaciju „Elasa” koja se u borbi sa monarhističkim i britanskim snagama u Grčkoj rukovodila iskustvom jugoslovenskog gerilskog pokreta.

${ }^{78}$ Isto, str. 132-134.
} 


\section{Jugoslovensko-albanski odnosi 1945-1947. godine}

Drugi važan faktor u uspostavljanju balkanske federacije bili su jugoslovensko-albanski odnosi za vreme i neposredno po završetku Drugog svetskog rata. Zbog nedostatka pouzdanih izvora teško je utvrditi da li je federaciji (između Jugoslavije i Bugarske) trebalo da pristupi i Albanija. Za razliku od projekata koji su egzistirali 1944/45. godine nema dokaza o postojanju formalnih planova koji bi se ticali tročlanog karaktera te federacije (Jugoslavija - Bugarska - Albanija), ili samo Jugoslavije i Albanije.

Još se u ratu očitovalo svojevrsno pokroviteljstvo KPJ prema albanskoj Komunističkoj partiji, a pobeda narodnooslobodilačkog pokreta u Albaniji, uz oslonac na novu Jugoslaviju, po završetku rata doprinela je snažnom usponu jugoslovensko-albanskih odnosa koji su obuhvatili uglavnom sve oblasti društvenog života, naročito ekonomsku i vojnu saradnju. Krajem aprila 1945. godine Jugoslavija je priznala albansku komunističku vladu i na svim međunarodnim konferencijama se zalagala da se Albaniji prizna status savezničke zemlje i dodele joj reparacije. Kada je u Parizu, krajem te godine, na konferenciji za reparacije Albaniji dodeljena minimalna reparaciona kvota, jugoslovenska delegacija je dala izjavu da je spremna da se u korist Albanije odrekne dela svoje kvote, mada je ona i za samu Jugoslaviju bila nedovoljna.

Između Albanije i Jugoslavije zaključen je niz sporazuma o privrednoj saradnji. ${ }^{79}$ Sporazumi koji su potpisani u drugoj polovini 1946. godine nisu bili samo korak dalje u razvijanju ekonomske saradnje dveju zemalja, već su jednim delom značili i jugoslovensko preuzimanje jednostranih obaveza prema susednoj državi. ${ }^{80}$ Jugoslavija je pomagala albansku privredu i stanovništvo, a na drugoj strani bila je i vojni štit ovoj zemlji koja se nalazila na osetljivom geopolitičkom prostoru. Pružala je Albaniji značajnu ekonomsku pomoć (u hrani, naoružanju, slanjem savetnika i stručnjaka, transportom reparacionog materijala za Albaniju, demontažom mlinova u Vojvodini i drugih tehničkih uređaja i njihovim slanjem Albaniji i dr.). Između dve susedne zemlje postignut je i dogovor o vođenju jedinstvene ekonomske politike i uspostavljanju mešovitih jugoslovensko-albanskih preduzeća. Zanimljivo je da su i veze između Moskve i Tirane, uključujući i isporuku naoružanja, u to vreme išle uglavnom preko Jugoslavije.

U julu 1946. godine u Tirani je zaključen Ugovor o prijateljstvu i uzajamnoj pomoći i Sporazum o privrednoj saradnji između FNRJ i NR Albanije (1. jula 1946), kojim je predviđeno stvaranje mešovitih albansko-jugoslovenskih akcionarskih društava. ${ }^{81}$ Krajem no-

\footnotetext{
${ }^{79}$ Enver Hodža je već u februaru 1945. godine uputio u Beograd delegaciju na najvišem nivou, sa punomoćjem da potpiše dva važna sporazuma sa Jugoslavijom - ekonomski i vojni. Poznato je da je 22. februara 1945. zaključen Ugovor o trgovinskoj razmeni i plaćanju između NKOJ-a i Demokratske vlade Albanije. Međutim, kada je reč o ugovoru o vojnoj saradnji, o njemu za sada nema tragova u domaćim arhivima.

${ }^{80}$ Aleksandar Životić, Pitanje Albanije u odnosima Jugoslavije i Zapada 1945-1947, Istorija 20. veka, Beograd, 2010, str. 84 .

${ }^{81} \mathrm{U}$ čl. 1. ovog sporazuma pisalo je: „Radi obnove i povećanja proizvodnih mogućnosti Narodne Republike Albanije i produbljivanja saradnje između FNR Jugoslavije i NR Albanije, vlada FNRJ i vlada NR Albanije odlučile su da pristupe organizovanju sledećih mešovitih albansko-jugoslovenskih akcionarskih drištava: Društvo za gradnju i eksploataciju železnica, Društvo za ekstrakciju i proizvodnju nafte, društva za istraživanje rudnika, eksploataciju i obradu ruda, Društvo za elektrifikaciju, Društvo za pomorsku plovidbu, Trgovačko društvo za uvoz i izvoz, Albansko-jugoslovenska banka". (Arhiv CK SKJ, IX - 8 - V/177).
} 
vembra 1946. godine došlo je do zaključenja Ugovora o usklađivanju privrednih planova, carinskoj uniji, ukidanju taksi i izjednačavanju valute. Obe vlade su se obavezale da u roku od mesec dana uklone carinske granice, stvarajući na taj način jedinstvenu carinsku teritoriju. ${ }^{82}$ Carinska unija s Albanijom stvarana je u vreme kada se Jugoslavija pripremala da pređe na plansku privredu i, uz sugestije Moskve, da se Albanija u političkom i privrednom razvoju osloni na Jugoslaviju. Politika unifikacije u privrednoj sferi dve države, koja je vođena od kraja 1946. godine, zapravo je značila da Jugoslavija žuri da stvori balkansku federaciju. Ugovorom o prijateljstvu i uzajamnoj pomoći Jugoslavija je preuzela obavezu i iskazala spremnost da brani nezavisnost Albanije. $U$ to vreme bilo je i govora o aneksiji Albanije, kao sedme jugoslovenske federalne jedinice. Međutim, realizacija tih ideja nije odgovarala albanskoj strani. ${ }^{83}$

Za vreme sovjetsko-jugoslovenskih razgovora u Moskvi, u maju 1946. godine, Staljin se nije protivio intenzivnoj saradnji Jugoslavije i Albanije, kao ni želji jugoslovenskog političkog vrha da Albanija, kao sedma federalna jedinica, uđe u sastav FNRJ. U tom kontekstu postojala je i ideja o pripajanju Kosova i Metohije Albaniji. Međutim, vrlo brzo će se pokazati da učvršćivanje vojno-političkih i ekonomskih veza između balkanskih zemalja generalno, koje je teklo mimo kontrole Moskve, Staljinu ipak nije bilo po volji. Bez obzira na to što je govorio da se zalaže za zbližavanje balkanskih zemalja, kasniji događaji će pokazati da u slučaju Jugoslavije i Albanije sovjetski lider nije blagonaklono gledao na njihove dobrosusedske odnose. Zbližavanje tri balkanske zemlje - Bugarske, Jugoslavije i Albanije, pri čemu je Jugoslavija sebi namenila lidersku ulogu u odnosima sa pomenutim državama, protivrečilo je zamišljenom hijerarhijskom modelu unutar socijalističkog lagera, sa jednim jedinim centrom - u Moskvi.

Ključno pitanje u odnosima između Jugoslavije i Albanije, kako u ratu, tako i po njegovom završetku, bilo je i ostalo pitanje Kosova i Metohije, zapravo statusa ove oblasti u slučaju da dođe do ujedinjenja Jugoslavije, Bugarske i Albanije. Centralni komitet KP Albanije je još od polovine 1943. godine tražio preko Miladina Popovića da se pitanje Kosova reši kao i pitanje Istre i Slovenačkog primorja, iako ova analogija u kosovskom slučaju nije bila primenljiva. $U$ isto vreme, za Tita nije moglo biti spora između dve zemlje oko ovog pitanja, pod uslovom da u Albaniji pobede „antiimperijalističke snage”, ili „progresivan režim”, kako je govorio Sreten Žujović godinu dana kasnije. Tito je 6. decembra 1943. godine pisao Svetozaru Vukmanoviću Tempu da „... nije potrebno naglašavati kako bi se to pitanje sutra postavilo ako Albanija zaista bude ostvarena kao demokratska antiimperijalistička državna tvorevina..." ${ }^{84}$ Uz činjenicu da pitanje Kosova nije posmatrao kao „problem” u odnosima između Jugoslavije i „demokratske antiimperijalističke Albanije”, Tito se u rešavanju albanskog pitanja rukovodio, pre svega, uverenjem da jugoslovenski narodnooslobodilački pokret zauzima centralno mesto na Balkanu: „Demokratski pokret”, tvrdio je, „treba gledati u njegovom razvitku, a sve činjenice govore da je on ne samo danas najsnažniji u Jugoslaviji,

\footnotetext{
${ }^{82}$ Arhiv CK SKJ, IX-8 - IV/139.

${ }^{83}$ B. Petranović, Istorija Jugoslavije 1918-1988, knj. 3, Beograd, 1988, str. 463; O odnosima Jugoslavije i Albanije videti kod: Ljubomir Petrović, kulturne veze Jugoslavije i Albanije 1946-1948, Istorija 20. veka, Beograd, 2009, str. 61-81; Aleksandar Životić, Jugoslavija i jačanje sovjetskog uticaja u Albaniji (1947-1948), Institut za noviju istoriju Srbije, Beograd, 2007, str. 94-117; Aleksandar Životić, Otvaranje albanskog pitanja u Jugoslaviji u senci sukoba između Jugoslavije i Informbiroa 1948-1954, Istorija 20. veka, br. 2, Beograd, 2009, str. 91-103.

${ }^{84}$ Josip Broz Tito, Sabrana djela, tom 18, Beograd, 1982, str. 18-20.
} 
nego da će u njoj dati i najbolje rezultate za budućnost. On je već sada glavna snaga na Balkanu". ${ }^{85}$ U tom kontekstu Edvard Kardelj je, aprila 1947. godine, u razgovoru sa Staljinom u Moskvi, govorio o predaji Kosova Albaniji. ${ }^{86}$

Rukovodstvo KPJ, kako tvrdi Branko Petranović, odlagalo je da se pitanje Kosova i Metohije rešava pre nego što se ostvari proces stvaranja nove balkanske grupacije država. Ukoliko bi do toga došlo, Kosovo je moglo pripasti Albaniji, ali pod uslovom da se izjednače društveni sistemi u političkom, državno-pravnom, ekonomskom i vojnom pogledu, a na drugoj strani ojača projugoslovenska struja u albanskom partijskom i državnom rukovodstvu. Pod tim uslovima Kosovo i Metohija bili bi prepušteni Albaniji, iako nema preciznih podataka o tome u kakvom bi statusu ova oblast ušla u sastav NR Albanije, da li kao članica buduće balkanske federacije ili kao sedma federalna jedinica Jugoslavije. ${ }^{87}$

Na stvaranju balkanske federacije radilo se tajno, bez odjeka u štampi, u bilateralnim razgovorima između maršala Tita i Envera Hodže, jugoslovenskih i albanskih partijskih, vojnih i državnih predstavnika. Srbija se nije pitala o sudbini Kosova i Metohije, iako se radilo o njenoj teritoriji i duhovnoj kolevci srpskog naroda. Tito je koncepciju federacije gradio na načelima AVNOJ-a, čime je osigurao brojčanu i realnu prednost jugoslovenskih federalnih jedinica, što za Bugarsku nije bilo prihvatljivo, a nije odgovaralo ni Albaniji, kao jedinoj potencijalnoj neslovenskoj jedinici u njenom sastavu. Na drugoj strani, Tito je bio svestan teškoća oko sprovođenja ideje o predaji Kosova i Metohije Albaniji, zbog moguće reakcije srpskog naroda, o čemu postoje tragovi u razgovorima između njega i Envera Hodže u junu i julu 1946. godine, koji su vođeni u Beogradu. Tito je imao u vidu i međunarodne probleme koji su mogli nastati usled promene balkanske političke mape, budući da se radilo o pitanju koje je prevazilazilo odnose balkanskih država. ${ }^{88}$ Italijanski zvaničnici i zapadna štampa su u vreme stvaranja carinske unije između Jugoslavije i Albanije, novembra 1946. godine, pominjali prepuštanje Kosmeta Albaniji, a na drugoj strani prenaglašavali aneksiju NR Albanije od strane Jugoslavije, kao sedme federalne jedinice. ${ }^{89}$

lako je Staljin bio rodonačelnik ideje o balkanskoj federaciji, jugoslovenski vođa ju je prihvatio kao takvu, modifikujući je i tragajući za modalitetima koji bi omogućili dominantan uticaj Jugoslavije u ovakvoj tvorevini. Sama ideja federacije u periodu od 1943. do 1948. godine izazivala je brojne negativne reakcije u SSSR-u, zemljama narodne demokratije i na Zapadu. Na nju se gledalo i kao na deo Titovih ličnih pretenzija, da bi ovaj, u Staljinovoj ponovljenoj inicijativi iz 1948. godine, u federaciji Jugoslavije s Bugarskom ipak video „trojanskog konja" kako bi se Jugoslavija lakše držala pod kontrolom ili iznutra oslabila. Pokazalo se, konačno, da je ova ideja štetila samoj Jugoslaviji i njenoj konsolidaciji posle rata, da je dovela do rasipanja sredstava i energije oko kombinacija koje nisu bile daleko od nezrelih i nepripremljenih koncepcija, a koje su nosile i pečat megalomanskih ličnih prohteva i ambicija.

\footnotetext{
${ }^{85}$ Arhiv CK SKJ, Fond SKJ, 1943/378.

${ }^{86}$ Arhiv Josipa Broza Tita. Zapisnik o razgovorima Staljin-Kardelj, koji je sačinio ambasador FNRJ u SSSR-u Vladimir Popović.

${ }^{87}$ Branko Petranović, Jugoslovensko-albanski odnosi 1945-1948. i naše manjine u NR Albaniji; U: Stanovništvo slovenskog porekla u Albaniji, Zbornik radova sa međunarodnog naučnog skupa održanog na Cetinju 21-23. juna 1990. godine.

${ }^{88}$ Enver Hodža, Titoisti, Beograd, 1982, str. 100-101, 284-286.

${ }^{89}$ B. Petranović, Jugoslovensko-albanski odnosi 1945-1948. i naše manjine u NR Albaniji.
} 
Odnosi između Jugoslavije i Albanije u periodu od 1945. do 1947. godine na prvi pogled delovali su idealno, ali se, u stvari, radilo o obostranom nezadovoljstvu. Dva rukovodstva, pored mnogih nesuglasica, razilazila su se i oko Kosova, koliko god njihovo neslaganje spolja bilo nevidljivo. Dok je Tito nastojao da se pitanje Kosova reši putem stvaranja balkanske federacije, Hodža je smatrao da kosovsko pitanje treba rešiti priključenjem ove oblasti NR Albaniji, nezavisno od buduće balkanske tvorevine. Na sličan problem nailazimo i u jugoslovensko-bugarskim odnosima, gde se postavljalo pitanje pripajanja Pirinske Makedonije Vardarskoj (jugoslovenskoj republici Makedoniji) pre stvaranja balkanske federacije, ili bar istovremeno sa njenim konstituisanjem, uključujući, na drugoj strani, i predaju tzv. zapadnih krajeva (Caribroda, odnosno Dimitrovgrada i Bosilgrada) Bugarskoj.

Od balkanske federacije ili ujedinjenja Albanije sa Jugoslavijom Hodža je strahovao iz više razloga: plašio se „rastvaranja” Albanaca u federaciji projektovanoj na pluralističkom principu po ugledu na avnojsku federaciju i njenog slovenskog karaktera. Osim toga, u njoj je video ugrožavanje i svog ličnog prestiža, pa i samog položaja u državi. Uprkos očekivanjima, od polovine 1943. godine, pitanje Kosova nije bilo rešeno u skladu sa proklamovanim principom prava naroda na samoopredeljenje, za koji se albanski lider zalagao. Iz izveštaja jugoslovenskih diplomata u Albaniji vidi se da i „najdalekovidiji rukovodioci ovde boluju u izvesnoj meri od velikoalbanske bolesti, tj. od uverenja da bi im trebalo dati Kosmet".

Na drugoj strani, pitanje prisajedinjenja Kosova i Metohije Albaniji i stvaranje balkanske federacije potisnuli su u pozadinu pitanje statusa manjinskog stanovništva u Albaniji, odnosno brigu da se zaštite i razvijaju kulturna i druga prava jugoslovenskih manjina u susednoj državi. Iz retkih izvora o jugoslovenskim manjinama, pre svega srpskoj u NR Albaniji, koji su sačuvani u arhivi SKJ, može se uočiti da prve informacije i pokušaji da se prikupe podaci o pripadnicima naše manjine (Srbima) i njihovim realnim problemima potiču tek iz februara 1948. godine, dakle uoči sukoba KPJ sa Informbiroom, što ne znači da nema i drugih izvora u državnim (jugoslovenskim) i republičkim arhivima, ali oni do danas nisu istraženi.

Odnosi Jugoslavije i Albanije (1945-1947) predstavljali su anticipaciju modela odnosa i sa Bugarskom. Broz je očekivao da Jugoslavija u balkanskoj federaciji dobije dominantno mesto, kao država sa šest realnih federalnih jedinica i sedmom - Albanijom kao potencijalnom jedinicom, i Bugarskom, sa kojom je tek trebalo ozakoniti Bledski dogovor (potpisan 1. avgusta 1947). Ideja koja se oslanjala samo na konture ove federacije sadržavala je mnogo nepoznanica kada je u pitanju proces njenog neposrednog oživotvorenja: hoće li se savladati potmuli otpor Albanije ukoliko ne dobije Kosovo i Metohiju; kako će reagovati Srbija i Crna Gora na predaju ovih oblasti; da li će Bugarska prihvatiti pluralističku strukturu federacije; ko će se nalaziti na čelu ove nove tvorevine; kako će reagovati Staljin - rodonačelnik ove ideje ; kakve su sve reperkusije mogle nastati na međunarodnom planu, pre svega kako će ovaj proces balkanskog zbližavanja odjeknuti na Zapadu i mnoga druga pitanja na koja se tada nije mogao ni naslutiti odgovor. ${ }^{91}$

\footnotetext{
${ }^{90}$ Arhiv CK SKJ, Fond SKJ, IX - 8 - V/218.

${ }^{91}$ B. Petranović, Balkanska federacija 1943-1948, str. 185-186.
} 


\section{Moskovsko opelo balkanskoj federaciji ${ }^{2}$}

Odnosi između Jugoslavije i Bugarske po završetku rata nastavili su da se razvijaju kroz zbližavanje u svim vitalnim oblastima: političkoj, vojnoj i ekonomskoj. Jugoslavija je pomagala konsolidaciju unutrašnjih prilika u Bugarskoj koje su bile više nego nepovoljne za vladu Otečestvenog fronta, ako se ima u vidu snažno delovanje bugarske opozicije potpomognute od zapadnih sila. Ovu liniju zbližavanja naročito je forsirao Georgi Dimitrov nakon povratka iz Moskve (1945. godine). ${ }^{93}$ Svojim odnosom prema Bugarskoj, Albaniji i Rumuniji, Jugoslavija je sprečavala zapadne sile da „pocepaju” jedinstvo balkanskih država nove (komunističke) orijentacije. Jugoslovenska štampa napadala je bugarsku opoziciju, nasuprot Britancima koji su je podržavali. Naime, Britanci su se trudili da razbiju jedinstvo balkanskih naroda, naročito da odvoje Jugoslaviju od Bugarske i izvrše pritisak na Rumuniju. ${ }^{94}$

Potpisivanjem mirovnog ugovora 1947. godine Bugarska je skinula sa sebe hipoteku poražene zemlje sa ograničenim međunarodnim kapacitetom. Ponovo su započele aktivnosti usmerene na stvaranje balkanske federacije, koja svoje obrise dobija već 1. avgusta 1947. godine, kada je na Bledu potpisan Sporazum o prijateljstvu, saradnji i uzajamnoj pomoći između Jugoslavije i Bugarske. Tom prilikom vlada FNRJ se odrekla reparacija u iznosu od 25 miliona dolara koje su joj bile određene po Mirovnom ugovoru sa Bugarskom. Zapad je u ovom sporazumu video ozbiljnu pretnju miru na Balkanu. Pretpostavljajući da se na pregovorima raspravljalo o pitanjima koja su se ticala stvaranja autonomne makedonske države, američki novinari su smatrali da je ovaj sporazum bio direktna pretnja Grčkoj u čijem sastavu se nalazila Egejska Makedonija. Bledski sporazum u Turskoj ocenili su kao „slovensku eksploziju”.

$\mathrm{Na}$ iznenađenje Beograda i Sofije, Moskva je takođe imala negativan stav po tom pitanju. Već 8. avgusta 1947. godine Staljin je poručio Dimitrovu da smatra greškom objavljivanje usaglašenog teksta Kominikea o ujedinjenju. Kritikovao je Dimitrovljevu izjavu o vremenskoj neograničenosti Bledskog sporazuma, jer to nije bilo prihvatljivo u međunarodnim odnosima. Staljin je upozoravao da će obnarodovanje ujedinjenja pre nego što bude ratifikovan mirovni ugovor sa Bugarskom, iako je do njegovog stupanja na snagu ostalo samo mesec dana, iskoristiti Amerikanci i Englezi da povećaju vojnu pomoć Grčkoj i Turskoj. Četiri dana kasnije, 12. avgusta 1947, Titu i Dimitrovu su uručeni telegrami sa identičnim sadržajem, u kojima je Staljin upozoravao balkanske lidere da „sovjetska vlada smatra da su obe vlade pogrešile zaključivši sporazum, uz to još na neodređeno vreme, pre stupanja na snagu mirovnog ugovora i uprkos njenom upozorenju". Izrečene su kritike na račun jugoslovenske i bugarske vlade, koje su „svojom brzopletošću olakšale posao reakcionarnim anglo-američkim elementima, dajući im nepotreban povod da povećaju vojno mešanje u grčke i turske poslove protiv Jugoslavije i Bugarske". U telegramu se naglašavalo da sovjetska vlada ne može preuzeti na sebe odgovornost za spora-

\footnotetext{
${ }^{92}$ Naslov je preuzet iz knjige Branka Petranovića, Balkanska federacija 1943-1948.

${ }^{93}$ Georgij Dimitrov (1882-1949), od 1935. do 1943. godine obavljao je dužnost generalnog sekretara Kominterne. Na inicijativu Dimitrova 1942. godine stvoren je Otečestveni front u Bugarskoj i razrađen njegov program. Dimitrov se vratio u Bugarsku 1945. godine. Nakon uzbora za veliko narodno sobranje (1946) on je bio prvi predsednik vlade NR Bugarske, a od decembra 1948. i generalni sekretar CK Bugarske radničke partije (komunista). Umro je u sanatorijumu blizu Moskve. (Miloš Šolaja, Balkan u transatlantskoj pukotini, Banja Luka, 2006, str. 33).

${ }^{94}$ B. Petranović, Balkanska federacija 1943-1948, str. 176-177.
} 
zume od „velike važnosti u oblasti spoljne politike” koji se zaključuju bez konsultacija sa njom. Dimitrov je, povodom ovih pretnji iz Moskve, već sledećeg dana (13. avgusta) uputio u Beograd šifrovani telegram, zahtevajući poništenje Bledskog sporazuma „do nastupanja”, kako se u njemu navodilo, „povoljnih okolnosti i konsultacija sa SSSR-om”, a Broz je 16. avgusta obavestio Moskvu da jugoslovenska vlada "nije imala nameru da stavlja pred svršen čin sovjetsku vladu", izrazivši spremnost da se objavi demanti, ukoliko Bugari budu bili saglasni s tim. ${ }^{95}$ Time su Jugoslavija i Bugarska svoje interese morale prilagoditi sovjetskim interesima na Balkanu.

Kako je Mirovni ugovor sa Bugarskom, potpisan na Pariskoj mirovnoj konferenciji februara 1947. godine, trebalo da stupi na snagu 15. septembra iste godine, Moskva je već 14. septembra (u telegramu Georgi Dimitrovu, koji su potpisali Staljin i Molotov) dala zeleno svetlo "da Vlade Bugarske i Jugoslavije mogu pristupiti ostvarivanju sporazuma o prijateljstvu i međusobnoj pomoći”. Na osnovu navedenog telegrama može se zaključiti da Broz i Dimitrov, u principu, nisu izašli iz okvira spoljnopolitičkog kursa koji je odredila Moskva. Jedina njihova „krivica” bila je u tome što je nisu obavestili o svojim namerama da pregovaraju na Bledu i što su obnarodovali informacije o ovom sporazumu mimo njenog znanja.

Tako će, u blizini Varne, 27. novembra 1947. godine, za vreme zvanične posete Josipa Broza Bugarskoj, biti održana službena ceremonija potpisivanja Sporazuma o prijateljstvu, saradnji i uzajamnoj pomoći između Jugoslavije i Bugarske. Prihvatajući Staljinovu sugestiju da takav sporazum ne može biti vremenski neograničen, ovoga puta on je pokrio period od 20 godina, sa mogućnošću daljeg produžavanja. ${ }^{96} \mathrm{U}$ zajedničkom kominikeu izdato je i saopštenje vezano za Balkansku komisiju, koju je formirao Savet bezbednosti. Obe zemlje su smatrale da je formiranjem te komisije prekršena Povelja OUN i princip državnog suvereniteta balkanskih naroda, pa su zato one odlučile da joj otkažu bilo kakvu saradnju i da joj zabrane ulazak na njihovu teritoriju. Zatim je i zvanično objavljen tekst Sporazuma.

Zapadne sile su jugoslovensko-bugarski savez shvatile kao ozbiljnu pretnju Grčkoj i njihovim interesima u tom regionu. Iz tog ugla posmatrana je i intenzivna saradnja između Jugoslavije i Albanije. Situacija se još više komplikovala kada su u decembru 1947. godine grčki komunisti formirali Privremenu demokratsku vladu, računajući da će ih priznati Beograd, Sofija i, možda, Moskva. Krajem decembra, preko beogradskog radija, Komunistička partija Grčke i Privremena vlada čestitali su Novu godinu grčkom narodu. Iz Atine je tim povodom reagovala zvanična vlada, uručivši oštru notu jugoslovenskom otpravniku poslova u Grčkoj; protestvovala je zbog javnog saopštenja o formiranju Privremene vlade koju su kontrolisali grčki komunisti, kao i zbog delovanja radiostanice „Slobodna Grčka” na jugoslovenskoj teritoriji.

Mogućnost priznavanja Privremene demokratske (komunističke) vlade Grčke od zemalja „narodne demokratije” u Vašingtonu bila je shvaćena kao uvod u otvorenu vojnu podršku Jugoslavije i Bugarske akcijama grčkih partizana. U Stejt Departmentu i Ministarstvu odbrane SAD razmišljalo se i o sprovođenju delimične mobilizacije u slučaju da

${ }^{95}$ D. D. Popović, Rezolucija Informbiroa $i$ 1948. godina u očima ruskih istoričara $i$ istraživača, feljton u listu „Dan”, 8-21. mart 2008.

${ }^{96}$ Tokom 1946. i 1947. godine Jugoslavija je, pored Bugarske i Albanije, zaključila ugovore o prijateljstvu i uzajamnoj pomoći s Poljskom, Čehoslovačkom, Mađarskom i Rumunijom.

${ }^{97}$ D. D. Popović, Rezolucija Informbiroa $i$ 1948. godina u očima ruskih istoričara $i$ istraživača, feljton u listu „Dan”, 8-21. mart 2008. 
dođe do upotrebe američkih jedinica u Grčkoj. U Velikoj Britaniji bili su takođe zabrinuti razvojem događaja u Grčkoj, o čemu svedoči i izjava britanskog ambasadora u Vašingtonu u kojoj se naglašavalo da njegova vlada smatra neophodnim da se upozore SSSR, Tito i Dimitrov da se „igraju vatrom”. Američki politički vrh se uzdržao od otvorenih optužbi na račun Moskve i ograničio samo na upozorenje upućeno Jugoslaviji, Bugarskoj i Rumuniji, naglašavajući da će njihovo eventualno priznavanje Privremene vlade u Grčkoj biti shvaćeno kao kršenje principa Povelje OUN. Ipak, postoje dokazi da se u američkoj administraciji u tom periodu raspravljalo o mogućem upućivanju američkih vojnika u Grčku i o mogućoj uzvratnoj reakciji Moskve na takav potez.

Sjedinjene Države su Jugoslaviju smatrale jednim od glavnih krivaca za izazivanje krize na Balkanu. U slučaju upada jugoslovenskih jedinica na grčku teritoriju, radi podrške grčkim partizanima, razmatrana je i mogućnost primene vojne sile protiv Jugoslavije. Izveštaj Saveta za nacionalnu bezbednost od 12. februara 1948. sadržavao je preporuku američkom predsedniku da se poveća vojna pomoć Grčkoj kako bi se umanjio uticaj „zemalja narodne demokratije", pre svih Jugoslavije na njihovog južnog suseda. Osim situacije u Grčkoj, Vašington su uznemiravali i planovi vezani za stvaranje federacije država sa prosovjetskim režimom u istočnoj Evropi, naročito posle izjave G. Dimitrova novinarima, 17. januara 1948. godine, koja se odnosila na stvaranje federacije od zemalja centralne i jugoistočne Evrope (podunavskih i balkanskih zemalja), ali i Poljske, Čhoslovačke i Grčke. Zapad je ovu izjavu okvalifikovao kao „sovjetski izum”. 98

Prilikom boravka u Bukureštu, januara 1948. godine, Dimitrov je izjavio kako je „preuranjeno" obrazovanje federacije zemalja istočne Evrope, ali je smatrao da će situacija vremenom sazreti. Po njemu, Rumunija, Albanija, Bugarska, Jugoslavija, Čehoslovačka, Poljska, Mađarska, pa čak i Grčka, same će odlučiti, u zavisnosti od sopstvene procene, da li će to biti federacija ili konfederacija. Bila je to, doduše, više njegova lična vizija organizacije istočne Evrope kao posebnog bloka država. Dimitrovljeva izjava je objavljena u Sofiji i Bukureštu 21. januara 1948, a „Pravda” ju je prenela 23. januara. Nakon pet dana u tom listu se pojavila i oštra kritika, jer se radilo o isuviše krupnoj inicijativi bez konsultacija sa Moskvom. Time se dovodila u pitanje i Staljinova neprikosnovena uloga u komunističkom svetu, a pomen Grčke mogao je izazvati krupne komplikacije u odnosima sa SAD i V. Britanijom.

Koliko je poznato, izjava koju je dao G. Dimitrov nije mogla odgovarati ni samom Titu. Njemu nije odgovarala ni Staljinova ideja južnoslovenske, odnosno balkanske federacije iz 1944-1945. godine, koja nije prošla zbog odbijanja zapadnih sila, a pitanje je koliko su se mogle usaglasiti bugarska koncepcija o dualnoj federaciji i jugoslovenska pluralistička federacija sa sedam federalnih jedinica. Jugoslovensko-bugarsko približavanje 1944-1947. godine temeljilo se na vlastitim interesima, iako u početku nije bilo van Staljinovih inicijativa. Prve kritike sovjetskog lidera usledile su zbog Bledskog sporazuma i njegovog oglašavanja pre nego što je Mirovni ugovor ratifikovan. Na Zapadu su se tada pitali: ko će biti na čelu te federacije: Dimitrov ili Tito, dajući prednost Titu kao mlađem i dinamičnijem, sa većim uticajem posle rata, u poređenju sa bivšim šefom Kominterne. ${ }^{99}$

$\mathrm{U}$ ovom periodu počele su da izbijaju na površinu i razlike u gledištima na buduću federaciju između jugoslovenskog i bugarskog rukovodstva. Dimitrov je smatrao da bi Ju-

\footnotetext{
${ }^{98}$ Isto.

${ }^{99}$ B. Petranović, Balkanska federacija 1943-1948, str. 197.
} 
goslavija i Bugarska trebalo da budu u jednakopravnom položaju, a Makedonija više pod okriljem Bugarske, dok je Broz i dalje insistirao na pluralističkom konceptu balkanske federacije. Njegovo stanovište nije odobravao Staljin, koji je od početka naginjao dualnom konceptu federacije. Osim toga, Broz je Makedonce smatrao zasebnim narodom, dok ih je Dimitrov video kao ogranak bugarskog naroda.

Izjava Dimitrova iz januara 1948. godine koja se odnosila na stvaranje federacije od zemalja centralne i jugoistočne Evrope, sa Poljskom, Čehoslovačkom i Grčkom, kao da je najavila početak razbuktavanja sovjetsko-jugoslovenskog konflikta koji će ubrzo potom uslediti. U telegramu Dimitrovu od 24. januara Staljin je oštro kritikovao njegovu izjavu, kao problematičnu i nerealnu, a i autorstvo članka u „Pravdi” od 28. januara, u kojem je takođe kritikovan Dimitrov, mnogi istraživači pripisuju Staljinu. lako se bugarski lider zvanično ogradio od svoje izjave, naglašavajući da je pitanje stvaranja federacije ili konfederacije preuranjeno i nije aktuelno, u Moskvi je odlučeno da se preduzmu ozbiljniji koraci kako bi se neutralisale nepovoljne međunarodne implikacije njegovog intervjua i znatno pojačala kontrola Moskve kada su u pitanju spoljnopolitičke aktivnosti njenih saveznika na Balkanu. U okolnostima kada je trebalo konsolidovati sve snage, Staljin nije mogao dozvoliti da bilo koja država saveznica iz „istočnog bloka” samostalno deluje, van kursa koji je osmišljen u Moskvi.

U tom kontekstu, ni „nepotrebno” uplitanje Jugoslovena u unutrašnje poslove Grčke i Albanije, u situaciji kada je postojala opasnost od mešanja SAD u grčka unutrašnja pitanja, očigledno nije odgovaralo scenariju napravljenom u Kremlju. I analitičarima u Vašingtonu bilo je jasno da SSSR ima za cilj da zadrži punu kontrolu u istočnoj Evropi. Američki ambasador u Moskvi Džordž Kenan je tvrdio da su ciljevi SSSR-a bili usmereni na kontrolu svih komunikacija na Balkanu, a dugoročni planovi okrenuti ka Egejskom, a manje ka Jadranskom moru.

Uzbuđenje u Moskvi povodom samostalnih akcija Beograda na Balkanu stalno je raslo. Uz to, kako se može videti iz objavljenih dokumenata, ono se pojačavalo pod uticajem izveštaja koji su dolazili iz Jugoslavije od sovjetskih predstavnika. Po njima, ponašanje jugoslovenskog rukovodstva bio je posledica nastojanja da vodi nezavisnu politiku u odnosu na Sovjetski Savez. Već u septembru 1947. godine, uporedo sa visokim ocenama jugoslovenske spoljne politike i pohvalama upućenih njenom rukovodstvu, ukazivalo se i na određene tendencije u precenjivanju sopstvenih dostignuća i težnju da jugoslovenska Komunistička partija zauzme posebno mesto „rukovodeće partije na Balkanu”. Otišlo se i korak dalje, pa su Jugosloveni okrivljeni za „suprotstavljanje unapređivanju sovjetsko-albanskih odnosa”. Bez obzira na to što je raspolagalo pouzdanim informacijama o jugoslovenskim namerama u Albaniji, sovjetsko rukovodstvo je, smatra Aleksandar Životić, ipak zaziralo od jugoslovenskih planova kada je u pitanju ova država. Nesporazumi između jugoslovenske i sovjetske strane o karakteru jugoslovenskog prisustva u Albaniji unosili su dodatnu zebnju u jugoslovensko-sovjetske odnose. ${ }^{100}$

O albansko-jugoslovenskim odnosima raspravljalo se u Moskvi početkom januara 1948. godine tokom susreta Staljina, Molotova i Ždanova sa Milovanom Đilasom. Delegacija koju je predvodio Đilas, u kojoj su se nalazili general Koča Popović, Milojko Todorović i Svetozar Vukmanović Tempo, otputovala je u Moskvu 8. januara 1948. godine, kako bi sa sovjetskom vladom razgovarala o usklađivanju politike Jugoslavije i Sovjetskog Saveza prema Albaniji, o pitanju ujedinjenja dveju balkanskih zemalja i postigla dogovor oko naoružanja i opreme za Jugoslovensku armiju.

\footnotetext{
${ }^{100}$ Aleksandar Životić, Jugoslovensko-sovjetske vojne suprotnosti (1947-1957), Beograd, 2015, str. 160.
} 
Iste večeri po dolasku u Moskvu Staljin je primio Đilasa, rekavši da Sovjetski Savez nema posebnih interesa u Albaniji i da nema ništa protiv da je Jugoslavija „proguta”. Đilas je insistirao da je reč o ujedinjenju dve zemlje, ali je Staljin ostao pri svom stavu. Isticao je da treba sačuvati formu albanske nezavisnosti, kao i da treba zadržati kolebljive ljude kao što je Enver Hodža, da se ne bi stvorio utisak eventualnog jugoslovenskog podjarmljivanja te zemlje. Razgovor između Đilasa i Staljina nije doneo dugo očekivano razjašnjenje sovjetske $\mathrm{i}$ jugoslovenske pozicije prema Albaniji, ali je jasno nagovestio nastavak mogućih neslaganja po tom pitanju. Đilas je stekao utisak da Sovjeti misle kako Jugosloveni u pogledu Albanije imaju isključivo ekspanzionističke namere. ${ }^{101}$

Ubrzo je došlo i do otvorenog razmimoilaženja između sovjetskog i jugoslovenskog vođstva. Staljin je jugoslovenskoj strani zamerio što je odlučila da u Albaniju uputi svoje trupe, a da se prethodno nije konsultovala sa Sovjetskim Savezom. Naime, Aleksandar Ranković je u ime Josipa Broza, 19. januara 1948. godine, upozorivši Envera Hodžu na opasnost od ozbiljnije oružane provokacije s grčke strane, zatražio da se rejon Korče proglasi jugoslovenskom vojnom bazom i da tu zonu zaposedne jedna jugoslovenska divizija radi organizacije zajedničke odbrane. Već sutradan, 20. januara, E. Hodža je dao saglasnost na jugoslovensku inicijativu. Međutim, u tom trenutku jugoslovensko rukovodstvo nije imalo jasnu predstavu o mogućoj sovjetskoj reakciji povodom vojnog angažovanja ove jedinice u Albaniji. ${ }^{102}$ Kako navodi Edvard Kardelj, jugoslovenska strana nije o tome obavestila Sovjete, računajući da će to učiniti albanski zvaničnici, što je Enver Hodža i učinio. Međutim, Molotov je prekorio jugoslovensko rukovodstvo što je dozvolilo da Sovjeti za jugoslovenske namere saznaju sasvim slučajno, dok su Albanci bili uvereni da postoji saglasnost sovjetske strane. ${ }^{103}$

Ova inicijativa Beograda (o slanju divizije u Albaniju) vremenski se poklopila sa Dimitrovljevom izjavom o stvaranju federacije centralnoevropskih i istočnoevropskih zemalja. Sovjetsko rukovodstvo je „uznemirilo” poklapanje „samovoljnih” radnji Bugara i Jugoslovena, naročito ako se ima u vidu da se to odvijalo po zaključenju bugarsko-jugoslovenskog sporazuma u Varni 27. novembra 1947. godine. S tim u vezi, Molotov je, 28. januara 1948. godine, uputio instrukcije Lavrentjevu, sovjetskom ambasadoru u Beogradu , da prenese Josipu Brozu kako je sovjetska strana dobila informaciju o namerama Jugoslavije da pošalje jednu diviziju u Albaniju i da se ona ne slaže s tim, jer bi zapadne sile mogle protumačiti takav akt kao narušavanje albanske nezavisnosti i, tim povodom, vojno intervenisati. $^{104}$

\footnotetext{
${ }^{101}$ Navedeno prema: A. Životić, Jugoslovensko-sovjetske vojne suprotnosti (1947-1957), str. 160-161.

102 Isto, str. 158-161; Činjenica je da su Sovjeti nastojali da u svakom trenutku raspolažu relevantnim informacijama o jugoslovenskom prisustvu u Albaniji. U tom smislu, glavni sovjetski vojni savetnik u Jugoslaviji general Barskov izveštavao je, 1. januara 1948, sekretara CK KPSS Mihaila Suslova o jugoslovenskoj pomoći Albaniji u vrednosti od oko dve milijarde dinara, unifikaciji albanske i jugoslovenske armije i jugoslovenskom potpunom snabdevanju albanske armije, kao i da su Albaniju krajem decembra 1947. godine posetili jugoslovenski načelnik Generalštaba general Koča Popović i dvojica zamenika načelnika Političke uprave jugoslovenskog Ministarstva narodne odbrane. Na savetovanju u albanskom Generalštabu Popović je izjavio da Jugoslavija prima na svoj budžet kompletnu albansku armiju i da u Albaniju šalje svoje vojne instruktore i savetnike, kao i da će u slučaju rata albanska, jugoslovenska i bugarska armija biti pod jedinstvenom komandom (Isto, str. 160).

${ }^{103}$ Isto, str. 161.

104 Isto.
} 
U razgovoru s Lavrentjevim Broz je insistirao na spoljnoj ugroženosti Albanije, a ovaj, opet, ukazivao na moguće implikacije ukoliko dođe do realizacije jugoslovenskog plana. Brozu je naročito skrenuta pažnja na neodrživost situacije u kojoj se jugoslovensko partijsko i državno rukovodstvo, u uslovima kada sa SSSR-om ima ugovor o uzajamnoj pomoći, ne konsultuje sa Sovjetima o tako važnoj stvari i da oni nisu spremni da snose odgovornost za posledice koje bi izazvao takav nepromišljeni potez. U takvoj situaciji Josip Broz je pokušao da smiri strasti, rekavši da je odluka o slanju divizije doneta na insistiranje albanske strane, ali da je ona povučena i da na sebe preuzima odgovornost za ovaj akt jugoslovenske vlade. Lavrentjev mu je na to prebacio da to nije prvi put da se jugoslovenska vlada ne konsultuje sa sovjetskom i da se ni 1947. godine nije konsultovala u pogledu potpisivanja ugovora sa Bugarskom. ${ }^{105}$

Da bi izvršila dodatni pritisak na Jugoslaviju i Bugarsku, Moskva je pozvala njihove predstavnike na nove konsultacije koje su održane u Kremlju 10. februara 1948. godine. U njima su sa sovjetske strane, pored Staljina, učestvovali Molotov, Ždanov, Maljenkov, Smislov i Zorin (zamenik ministra spoljnih poslova SSSR-a), sa Bugarske - Dimitrov, Kostov i Kolarov, a jugoslovensku delegaciju predstavljali su Edvard Kardelj i Vladinir Bakarić. Iz memoara E. Kardelja saznajemo da je Broz odustao od puta u Moskvu, pod izgovorom da se ne oseća dobro. Sastanak je protekao u duhu oštrih kritika Staljina i Molotova upućenih Jugoslovenima i Bugarima povodom pogrešno vođene spoljne politike, a koju Moskva ipak nije kaznila.

U oštroj i ne baš diplomatskoj formi Staljin je skrenuo pažnju da su nezavisnost Albanije garantovale tri sile pobednice u Drugom svetskom ratu i da bi ulazak jugoslovenskih vojnih snaga u Albaniju zapadne sile mogle da protumače kao ugrožavanje njene nezavisnosti. Za njega je Albanija predstavljala najosetljiviju tačku istočnog bloka, pa je savetovao da joj Jugoslavija svim silama pomogne u slučaju da bude napadnuta, ali da pre toga ne upućuje trupe na njenu teritoriju, jer bi Zapad u tom slučaju Jugoslaviju proglasio za agresora. Staljin je u razgovoru pomenuo i pitanje balkanske federacije koja, po njemu, nije mogla da egzistira kao tročlana, već dvočlana federacija, između Jugoslavije i Bugarske, dok je Albaniju video u sastavu jugoslovenske države, kao jednu od njenih federalnih jedinica, koja bi u tom svojstvu i ušla u balkansku federaciju.

Staljin je direktno prekorio Dimitrova i Kardelja zbog toga što bugarsko i jugoslovensko rukovodstvo svojim postupcima ne vodi računa o mogućem komplikovanju odnosa Sovjetskog Saveza sa zapadnim zemljama. Iz njegovog nastupa bilo je jasno da Sovjeti zaziru od zapadnih reakcija, ali i od jačanja balkanskog korpusa unutar socijalističkog lagera koji izmiče njihovoj kontroli. Ulazak jugoslovenskih trupa u Albaniju ovim razgovorom definitivno je skinut $s$ dnevnog reda, iako je jugoslovenskoj strani u isto vreme savetovano da i dalje pomaže jačanje albanske oružane sile kako bi ova država bila osposobljena za ozbiljniji otpor eventualnoj agresiji. Tako je, bar privremeno, amortizovan sukob po pitanju Albanije, iza kojeg se ipak nazirao obris budućeg sovjetsko-jugoslovenskog konflikta koji će poprimiti mnogo šire i ozbiljnije razmere.

Svojim postupkom jugoslovensko rukovodstvo je ozbiljno narušilo postojeću hijerarhiju i sistem odlučivanja unutar sovjetskog bloka, što je pretilo da izazove konflikte širih razmera između dve partije. ${ }^{106}$ Sovjetska strana je načelno priznavala slobodu jugoslo-

${ }^{105}$ Isto, str. 162

${ }^{106}$ B. Petranović, Balkanska federacija, str. 339. 
venskog delovanja na tlu Albanije, ali samo do one granice do koje se to ne bi kosilo sa sovjetskim interesima i narušavalo uspostavljeni hijerarhijski poredak unutar socijalističkog lagera. Jugoslovenska akcija u Albaniji rezultirala je sovjetskim zahtevom da se potpiše poseban protokol o obaveznom konsultovanju sa Sovjetskim Savezom kada je reč o važnim spoljnopolitičkim pitanjima. Protokol je potpisan već 13. februara 1948. godine. Istovetan ugovor potpisan je i sa Bugarskom. To je trebalo da znači da će Sovjetski Savez ubuduće strogo kontrolisati spoljnopolitičke akcije Jugoslavije i Bugarske. Sovjetski partijski vrh je strahovao od mogućih ishitrenih poteza svojih balkanskih saveznika koji bi mogli da poremete odnose sa Zapadom, kao i ugovorne obaveze koje je Sovjetski Savez preuzeo na sebe tokom Drugog svetskog rata, a kojih se Staljin i dalje pridržavao. ${ }^{107}$

Kriza u jugoslovensko-sovjetskim najavila je i krizu u jugoslovensko-albanskim odnosima, koja je otpočela krajem 1947. i početkom 1948. godine. Jugoslovenska namera da u Albaniju uputi jednu diviziju bez prethodnog obaveštavanja sovjetske vlade predstavljala je detonator budućeg sukoba između Albanije i Jugoslavije. lako je taj događaj predstavljao samo povod, uzroci su bili mnogo dublji i moraju se tražiti kako u jugoslovenskoalbanskim protivrečnostima od 1944. do 1948. godine, tako i u sovjetskom nastojanju da uređuje odnose na Balkanu, shvatanju uloge Jugoslavije i njenog prisustva u Albaniji, kao i sagledavanju albanske pozicije unutar socijalističkog sveta. Važan problem u odnosima između Sovjetskog Saveza, Albanije i Jugoslavije bilo je pitanje Grčke. Na osnovu dostupnih izvora, tvrdi Aleksandar Životić, sasvim je jasno da Sovjetski Savez nije želeo dublji konflikt u Grčkoj, te da je nastojao da kontroliše svoje balkanske saveznice koje su pružale pomoć grčkom gerilskom pokretu. Suviše jaka jugoslovenska pozicija na Balkanu, iskustvo autohtone revolucije i mogućnost da Jugoslavija preko Albanije izađe na Sredozemlje pretili su da, gledano iz sovjetskog ugla, postanu problem unutar socijalističkog sveta. Za Jugoslaviju će sukob sa Albanijom, koji se početkom 1948. godine jasno nazirao, predstavljati snažan udarac ne samo na političkom i vojnom, već i na ekonomskom planu, usled velikih investicija u Albaniji koje jugoslovenska vlada nije mogla da povuče, a koje su ratom opustošenoj zemlji poput Jugoslavije bile preko potrebne.

U takvoj situaciji, koja je podrazumevala beskompromisno potčinjavanje interesa zemalja „socijalističkog lagera” interesima prve zemlje socijalizma, a ona bila u prilici da kontroliše i kanališe unutrašnju i spoljnu politiku svojih saveznica i sputava slobodu njihovog delovanja, balkanska federacija za jugoslovensko rukovodstvo pokazala se kontra produktivnom. Na sednici CK KPJ od 19. februara 1948. godine, na kojoj je jugoslovenska delegacija podnela izveštaj o svojoj poseti Moskvi, doneta je odluka da se odustane od ujedinjenja sa Bugarskom. Na narednoj, proširenoj sednici Politbiroa CK KPJ, 1. marta 1948, odbijena je Staljinova inicijativa iz februara iste godine za formiranje balkanske federacije. Prema generalnom sekretaru KPJ, za federaciju nisu sazreli uslovi: „Realne mogućnosti federacije sada nisu najbolje. Mi smo federaciju stvorili u toku rata. Sada je učvršćujemo i još treba da radimo. Da li je sada celishodno postaviti pitanje federacije? Pitanje Caribroda, Bosilgrada? Pirinska Makedonija - podeljena na srezove. Dosadašnji stav bugarskih drugova nije se izmenio i to zabrinjava..."109

\footnotetext{
${ }^{107}$ A. Životić, Jugoslovensko-sovjetske vojne suprotnosti (1947-1957), str. 164.

${ }^{108}$ Isto, str. 177-178.

${ }^{109}$ B. Petranović, Balkanska federacija, str. 201.
} 
$\mathrm{Na}$ ovom sastanku preovladalo je gledište da Jugoslaviji u tom času ne odgovara stvaranje federacije sa Bugarskom, dok saradnju sa Albanijom nije trebalo napuštati: „Albaniju treba čvrsto držati, jer smo mnogo uložili i ona je za nas važna". U vreme izbijanja krize sa SSSRom, jugoslovensko rukovodstvo je nastojalo da zadrži uticaj u Albaniji zbog geopolitičkog značaja njene teritorije za Jugoslaviju, velikog ulaganja u albansku privredu i vojsku i albanskog stanovništva na Kosovu i Metohiji. ${ }^{110}$ Albanija će se, međutim, u sukobu koji je eskalirao objavljivanjem Rezolucije Informbiroa, u junu 1948. godine, okrenuti protiv Jugoslavije.

Sovjetska strana odlučno je reagovala 19. marta 1948. godine opozovom svojih vojnih stručnjaka (savetnika) i instruktora iz Jugoslavije pod izgovorom da se prema njima postupalo neprijateljski. Usledio je početak snažne antijugoslovenske kampanje iz Moskve, koja će rezultirati beskompromisnim sukobom i potpunim razlazom Jugoslavije sa SSSR-om i zemljama „Narodne demokratije”. Sve se to događalo bez znanja jugoslovenske javnosti, a bilo je praćeno tajnim pismima iz Moskve koja su sadržavala neviđene političke i ideološke optužbe na račun jugoslovenskog partijskog rukovodstva. ${ }^{111}$ Sukob između Satljina i KPJ 1948. godine dovešće do političke, ekonomske i vojne izolacije Jugoslavije, ozbiljnih pretnji vojnom intervencijom i korenitih promena u odnosima među balkanskim državama. On će, istovremeno, zapečatiti i sudbinu ideje o balkanskoj federaciji koja je egzistirala punih stotinu godina na ovim prostorima.

\section{Iskustva jugoslovenskog federalizma (1943-1991)}

Strategija KPJ u nacionalnoj politici između dva rata počivala je na sintagmi o srpskoj prevlasti koju je trebalo uništiti i osloboditi ostale narode od velikosrpske hegemonije i velikosrpskog centralizma. „Jednom stvorena teza o velikosrpskom hegemonizmu”, piše B. Petranović, „pretvarana je u stereotip i trajnu hipoteku koja traje do našeg vremena. Od nje se ne odustaje, kao da se polazi od postavke da neistina stalnom upotrebom postaje istina, delotvorna na svest, u smislu mobilizacije hrvatskog nacionalizma i svih antisrpskih snaga..."112 lako su nakon osvajanja vlasti (1945), prema Todoru Kuliću, predrasude komunista o nacionalizmu najbrojnijeg naroda ustupile mesto tezi o podjednakoj opasnosti od svih nacionalizama, a federativnim uređenjem Jugoslavije na avnojevskim principima slabila kritika velikosrpstva, „Tito je kao `habzburgovac podozrevao od Srbije i zazirao od najmoćnije nacije”. ${ }^{113}$ Kao pripadnici „vladajuće” nacije, i srpski komunisti su delili sudbinu sopstvenog naroda. Nji-

\footnotetext{
${ }^{110}$ Isto, str. 200.

111 Jerzi Holzer, Komunizam u Evropi, povijest pokreta i sustava vlasti, Zagreb, 2002, str. 77.

112 Branko Petranović, Srbija u Drugom svetskom ratu 19339-1945, Beograd, 1992, str. 36. O poreklu ove teze Petranović piše: „...Ako se ima u vidu austrougarsko poreklo teze o tzv. velikosrpskom hegemonizmu, kao vidu borbe protiv Srbije i širenja srpskog uticaja među jugoslovenskim stanovništvom monarhije pre i naročito posle balkanskih ratova, onda ne začuđuje da su nju prihvatile i posle 1918. godine sve antijugoslovenske i antisrpske snage, kako u zemlji, tako i u inostranstvu. Naročitu primenu našla je u političko-propagandnom istupanju revizionističkih država posle zaključenja mirovnih ugovora, revanšističkih snaga u Nemačkoj i Kominterne posle njenog osnivanja 1919. godine. Kominterna će tezu o velikosrpskom hegemonizmu tazvijati preko svoje nacionalne sekcije KPJ koja je punu deceniju radila na razbijanju Jugoslavije (1925-1935) kao versajske tvorevine, tamnice naroda, države srpske buržoazije, u kojoj ugnjetačka srpska buržoazija tlači ostale nesrpske narode..." (Isto.)

${ }^{113}$ Todor Kulić, Tito, Sociološko-istorijska studija, Beograd, 1988, str. 87.
} 
hov najvažniji zadatak bio je da se bore za rušenje režima „velikosrpske buržoazije” i jugoslovenske države, kako bi pomogli borbu za stvaranje nezavisnih država „ugnjetenih” naroda, odnosno pružili podršku nacionalnoj borbi hrvatskog i drugih nesrpskih naroda u okviru zajedničke države. Razlike između srpskih i hrvatskih komunista ogledale su se, pre svega, u tome što su prvi morali da budu isključivo internacionalistički orijentisani, a drugi su se mogli nacionalno opredeljivati. ${ }^{114}$ Ta podela preneće se i na kasniji, ratni period.

Nacionalna politika u kojoj se KPJ tokom Drugog svetskog rata oslanjala na predratno nasleđe (naročito druge polovine tridesetih godina) predstavljala je jedan od postulata njene strategije osvajanja vlasti i po završetku tog rata. Ona se temeljila na ideji i praksi federalizma, formalno sankcionisanoj proglašavanjem Jugoslavije kao federativne zajednice ravnopravnih naroda na drugom zasedanju AVNOJ-a, novembra 1943. godine. Komunistički koncept jugoslovenske federacije u ratu razdvajao je srpski narod u posebne entitete (srpski i crnogorski) kao i pre rata, a na drugoj strani ostavljao ga u Hrvatskoj i Bosni i Hercegovini, načelno, u svojstvu konstitutivnog naroda. Zamišljena kao „federacija ravnoteže”, jugoslovenska federacija posle AVNOJ-a građena je na koncepciji „umanjene Srbije” u kojoj su komunisti videli protivtežu „velikoj” ili „,homogenoj Srbiji”. Teritorijalnim uobličavanjem jedino Srbije kao složene federalne jedinice 1945. godine (dodeljivanjem Vojvodini i Kosovu i Metohiji statusa autonomnih oblasti, a zatim i pokrajina u sastavu Srbije), iako su postojale pretpostavke za obrazovanje autonomija i u okviru drugih federalnih jedinica, Jugoslavija je predstavljala „tipičnu kompromisnu građevinu” federacije ravnoteže na štetu Srbije i srpskog naroda u celini, a ne ravnoteže sa stanovišta uspostavljanja stvarnih simetričnih odnosa, ili bar približnih, koji bi u višenacionalnoj zajednici mogli doprineti njenoj stabilnosti. ${ }^{115}$

Prilikom oblikovanja federalnih jedinica, u toku rata nije došlo do utvrđivanja njihovih granica. Pitanje konačnog razgraničenja, kao veoma osetljivo, ostavljeno je po završetku rata, ali do njega nije došlo. Ustavom FNRJ iz 1946. godine utvrđena su prava i dužnosti republika i njihov položaj u zajedničkoj državi, a da pri tom nisu pravno utvrđene ni definisane njihove granice. Teritorijalno-administrativna podela Jugoslavije nije utemeljena nijednim pravnim aktom nadležnog federalnog organa. Ovakav odnos prema vitalnom pitanju koji se ticao uređenja države čije su unutrašnje granice tretirane kao formalne bio je moguć samo u jednopartijskom sistemu ustanovljenom posle rata i neograničenoj moći partijskih struktura u državnoj upravi, gde je politička reč bila jača od pravnog sistema, a moć pojedinca gotovo neograničena. ${ }^{\uparrow 6}$ Sa nestankom ovih integrativnih činioca osamdesetih godina prošlog veka, koji su ustupili mesto nacionalnim elitama i političkoj volji višepartijskih struktura u jugoslovenskim republikama, rukovođenim sopstvenim interesima, došlo je do neminovne dezintegracije savezne države i njenog raspada devedesetih godina.

Od početka Drugog svetskog rata KPJ je zagovarala obnovu Jugoslavije kao zajednice ravnopravnih i suverenih naroda. Njeno jugoslovenstvo počivalo je na akcionoj paroli „bratstva i jedinstva” i odbacivanju svakog nacionalnog revanšizma; predratnom režimu „socijalnog eksploatisanja” suprotstavljala je parolu „socijalne jednakosti”, a politici pode-

\footnotetext{
114 O tome je partijski organ Proleter, 1. januara 1937. godine, pisao: „Hrvatski komunista nije neki internacionalista koji visi u zraku, nego je on komunista - Hrvat, tj. komunista koji se svim snagama zalaže za pobjedu hrvatskog naroda. Za srpskog komunistu internacionalizam znači u prvom redu doslednu borbu protiv velikosrpske politike srbijanskih vladajućih klasa".

${ }^{115}$ B. Petranović, Jugoslovensko iskustvo srpske nacionalne integracije, str. 79-101.

${ }^{116}$ Isto.
} 
le zemlje, koncepciju obnovljene i jedinstvene Jugoslavije uređene na federativnom principu, koja je podrazumevala i legitimno pravo na samoopredeljenje, uključujući i pravo na otcepljenje i ujedinjenje sa drugim narodima. ${ }^{117}$ Ovakav koncept nacionalne politike KPJ počivao je na negaciji „hegemonije” najbrojnijeg naroda u Jugoslaviji („velikosrpskog hegemonizma"), na ideološkim stereotipima kojih se partija nije odrekla ni u uslovima Drugog svetskog rata, a ni posle rata. U okolnostima potpune egzistencijalne ugroženosti, u kojima su Srbi kao žrtve masovnih progona i pogroma doživljavali najtežu sudbinu u svojoj novijoj istoriji, klasno-revolucionarna operacionalizacija mita o velikosrpskoj hegemoniji, odnosno optužbe na račun „dvadesetogodišnje krvave pljačkaške vladavine velikosrpske gospode nad radnim masama i ugnjetenim narodima”, „nacionalnog ugnjetavanja” i „trgovanja sa zemljom na pijaci imperijalističkih razbojnika (Engleske, Francuske, Amerike, Nemačke, Italije)," a zatim, optužbe za slom u Aprilskom ratu za koji je krivica pripisana „srpskoj buržoaziji”118 itd., zvučale su u najmanju ruku apsurdno i deplasirano, ali sa aspekta partijske politike i strategije - svrsishodno i funkcionalno. Ocene o „velikosrpskoj Jugoslaviji” i Hrvatskoj kao centru otpora protiv „Versajske Jugoslavije” nisu ni posle njenog razbijanja (aprila 1941) iščezle iz arsenala komunističke propagande. Njeni agitatori, kao i sami komunistički prvaci, izricali su ih i na završetku rata, u vreme kada su Srbi pružali najviše dokaza svoje lojalnosti novoj Jugoslaviji. Za vreme Drugog zasedanja AVNOJ-a Broz je u razgovoru sa hrvatskim većnicima isticao da Hrvatska igra „važnu ulogu, jer su Hrvati i Hrvatska bili nosioci borbe protiv velikosrpske reakcije", i da je u „sklopu zajedničke borbe Hrvatska jak stub, ako se iznutra iscementira tada će Hrvatska i Hrvati odigrati veliku ulogu". ${ }^{119}$ Andrija Hebrang je na skupštini ASNOS-a, novembra 1944. godine u Beogradu, takođe govorio o Hrvatskoj kao ,jednom od najsnažnijih stubova nove demokratske federativne Jugoslavije". ${ }^{120}$

Velikosrpski hegemonizam napadan je i u uslovima dominantne zastupljenosti Srba u boračkom sastavu NOVJ, uprkos činjenici da su oni, naročito do kapitulacije Italije (septembra 1943), činili većinu u njenom komandnom kadru. U „Proleteru” (organu KPJ) Broz je decembra 1942. pisao da je „versajska Jugoslavija bila tipična zemlja nacionalnog ugnjetavanja, u kojoj su Hrvati, Slovenci i Crnogorci bili potčinjeni, Makedonci, Arnauti i drugi porobljeni i podvrgnuti istrebljenju, a Muslimani, nemačka i mađarska manjina služili su kao moneta za potkusurivanje ili kao instrument u borbi protiv Hrvata i drugih naroda Jugoslavije. Zemljom je vladala brojčano neznatna manjina srpskih hegemonista koja je izrabljivala i vlastiti srpski narod”. Brozov tekst o „Nacionalnom pitanju u Jugoslaviji u svjetlosti narodnooslobodilačke borbe” (objavljen u „Proleteru” decembra 1942) sadržavao je jednu od njegovih retkih izjava iz ratnog perioda da se u redovima NOV i POJ „od samog početka nalaze u ogromnoj većini baš Srbi, umjesto da tu bude obratno. Baš srpski, crnogorski, bosanski i lički partizani i brigade koje su bile sastavljene gotovo isključivo od Srba vodili su i danas

\footnotetext{
${ }^{117}$ Dokumenti o spoljnoj politici SFRJ 1941-1945, knj. II, Beograd, 1989, str. 23-24, 25-27; Odluka Drugog zasedanja AVNOJ-a o izgradnji Jugoslavije na federativnom principu; Pismo J.B.Tita Centralnom komitetu KP Albanije od 2. decembra 1943.

${ }^{118}$ Zbornik dokumenata i podataka o narodnooslobodilačkom ratu naroda u narodnosti Jugoslavije (kraće: Zbornik NOR-a), Vojnoistorijski institut, tom 1, knjiga 2, str. 11-16; Proglas Pokrajinskog komiteta KP za Srbiju, juni 1941. godine.

${ }^{119}$ AVNOJ i revolucija, Zbornik dokumenata, Priredili B. Petranović i S. Nešović, Beograd, 1983, str. 459-460.

${ }^{120}$ Velika antifašistička narodnooslobodilačka skupština Srbije, 9-12. novembar 1944, Beograd, 1945, str. 34.
} 
vode nemilosrdnu borbu ne samo protiv okupatora već i protiv četnika Draže Mihailovića i ostalih neprijatelja ugnjetenih naroda”. Ovu izjavu o „najvećem doprinosu u krvi koji srpski narod daje u borbi protiv okupatora i njegovih izdajničkih slugu”, „za punu slobodu i nezavisnost svih naroda Jugoslavije”, ${ }^{21}$ zameniće ubrzo formulacije o „prolivanju krvi svih naših naroda”, parole o „ravnopravnosti, bratstvu i jedinstvu” kao vrhunskim vrednostima i dosledno isticanje nacionalne simetrije kada su u pitanju zasluge i borbeni učinak u ratu.

Svojom teritorijalnom organizacijom, ustanovljenom pre i institucionalno dograđenom u toku Drugog svetskog rata, KPJ je anticipirala buduće unutrašnje uređenje jugoslovenske države. Predratna regionalna političko-partijska institucionalizacija u Srbiji, Vojvodini, Kosovu i Metohiji, Sandžaku od jeseni 1941, Crnoj Gori, Bosni i Hercegovini i Makedoniji, koja je razdrobila srpski etnički prostor, tokom rata će se (zajedno sa vojnom) još više razgranati u mrežu brojnih partijskih komiteta, antifašističkih veća, glavnih štabova, narodnooslobodilačkih odbora i narodnofrontovskih organizacija. Na taj način, od prvih dana ustanka tekao je proces nastajanja jugoslovenske federacije kroz razgradnju srpskog etničkog prostora. Karakterističan primer u anticipiranju ideje federalizma predstavljalo je vojno savetovanje u Stolicama, septembra 1941. godine, kada je doneta odluka o formiranju (pored Vrhovnog štaba) i glavnih štabova kao vojnih rukovodstava u jugoslovenskim zemljama... ${ }^{122}$

lako pitanje federalizacije jugoslovenske države nije eksplicitno naglašavano u prvim godinama rata, „revolucionarni subjekt” imao je od početka jasan stav prema nacionalnom pitanju koje je bilo neodvojivo povezano sa teritorijalnim uređenjem buduće države. Parola da „nema povratka na staro” značila je, u osnovi, odbacivanje „prošlih režima”, negiranje stare teritorijalne podele zemlje (na banovine) i raskid sa socijalnim i nacionalnim nasleđem Kraljevine Jugoslavije. ${ }^{123}$ Odnos prema nacionalnom pitanju bio je od samog početka prisutan i načelno definisan u štampi i proglasima narodnooslobodilačkog pokreta, internim instrukcijama, govorima i člancima njegovih prvaka, ali se o pojedinostima oko razgraničenja potencijalnih federalnih jedinica rukovodstvo KPJ nije izjašnjavalo. ${ }^{124}$

Prvi temeljniji pristup ovom pitanju izložio je Josip Broz u partijskom organu „Proleter”, decembra 1942. godine, člankom „Nacionalno pitanje u Jugoslaviji u svjetlosti narodnooslobodilačke borbe", koji je predstavljao i prvi programski koncept nacionalne politike KPJ u ratu. Naglašavajući na početku dokumenta da su narodno-oslobodilačka borba i nacionalno pitanje u Jugoslaviji „nerazdvojno vezani”, Broz je jasno definisao strategiju borbe pokreta na čijem je čelu bio: „...Reč - narodnooslobodilačka borba - bila bi samo jedna fraza, pa čak i prevara, kad ona ne bi imala osim opšte jugoslovenskog smisla i nacionalni smisao za svaki narod posebice, tj. kada ona ne bi značila, osim oslobođenja Jugoslavije, u isto vreme oslobođenje Hrvata, Slovenaca, Srba, Makedonaca, Arnauta, Muslimana itd, kada narodnooslobodilačka borba ne bi imala tu sadržinu da zaista nosi slobodu, ravnopravnost i bratstvo svih naroda Jugoslavije..." Taktički sinhronizovan sa žestokom kampanjom protiv četnika, Brozov članak ujedno je bio i otvoreni poziv na obračun sa „velikosrpskom reakcijom”, „velikosrpskom hegemonističkom klikom” u liku Mihailovićevog pokreta i njegovih mentora iz Londona (kralja Petra II i Jugoslovenske vla-

\footnotetext{
${ }^{121}$ Izvori za istoriju SKJ, NOR i tevolucija, Beograd, knj. 9, str. 338-345; Proleter, br. 16, decembar 1942.

${ }^{122}$ Lj. Dimić, Srbija u Jugoslaviji, knj. III, str 263-264.

${ }^{123}$ Branko Petranović, Momčilo Zečević, Jugoslovenski federalizam - ideje i stvarnost, 1, Beograd, 1987, str. 741-747.

${ }^{124}$ B. Petranović, Srbija, str. 522.
} 
de), pozivajući u redove Narodnooslobodilačke vojske i partizanske odrede podjednako Srbe, Hrvate, Slovence, Crnogorce, Makedonce i muslimane. ${ }^{125}$ Brozov članak je „nudio” perspektivu slobode, ravnopravnosti i nacionalne emancipacije svim jugoslovenskim narodima koji se svrstaju uz Narodnooslobodilački pokret, a Hrvatima i Muslimanima istovremeno i spas od „bratoubilačkog rata”, od četničkog revanšizma i odmazde za stradanja srpskog naroda u ustaškom pogromu.

Dok je vođstvo Narodnooslobodilačkog pokreta, pre svega Broz, vodilo žestoku kampanju protiv Mihailovićevog pokreta, u nameri da ga potpuno diskredituje pred saveznicima i odvoji od njih, Srbija je tokom celog rata bila zaplašivana duhom četništva i „dražinovštine", kojeg se ni po njegovom završetku nije mogla dugo osloboditi. Srbi pripadnici NOVJ imali su posebnu dužnost, isticao je Koča Popović novembra 1944. godine, „da speru ljagu koju su na Srbiju, na čitav srpski narod, pokušali da bace koljači, hegemonisti Draže Mihailovića, koji su pokušali da na krvi naroda stvore i očuvaju sebi položaje". ${ }^{126}$ I na samom kraju rata, na Osnivačkom kongresu Komunističke partije Srbije, maja 1945. godine, kao glavni zadatak komunista u Srbiji označena je „neumorna borba protiv velikosrpskog šovinizma i hegemonizma” i „protiv ostataka dražinovštine i fašizma u svim vidovima". Srpski komunisti su pozivani da i među nacionalnim manjinama budu nosioci borbe protiv šovinizma. ${ }^{127}$ Time je hipoteka velikosrpske vladavine, uspostavljena pre rata, nastavljala da živi i po njegovom završetku; na njoj se zasnivala nacionalna politika KPJ koja je zahtevala od Srba da ne pokreću svoje nacionalno pitanje, a ostalim narodima i manjinama omogućavala u punoj meri da institucionalno izraze svoj nacionalni identitet u okviru buduće jugoslovenske federacije. Građena po principu nacionalne federacije - koliko nacija toliko i federalnih jedinica (sa izuzetkom Bosne i Hercegovine), ona je razdrobila srpski etnički prostor. Jedino je od Srbije načinila federaciju unutar federacije (složenu federalnu jedinicu), dok je značajan deo srpskog naroda ostavljen van svoje matice. Time je (u državno-pravnom smislu) dovršena teritorijalna i institucionalna razgradnja srpskog nacionalnog korpusa i eliminisana potencijalna „opasnost” od vaskrsavanja „srpske hegemonije” u „drugoj” Jugoslaviji.

Rešenja koja je afirmisao AVNOJ u Jajcu (novembra 1943) i njihova implementacija, kao i kasnija dogradnja jugoslovenske federacije, ukazivali su na to da je i nacionalni aspekt srpskog pitanja, onako kako ga je KPJ tretirala, bio u funkciji njene političke strategije osvajanja vlasti, a da se pri tom o interesima Srbije i srpskog naroda u celini nedovoljno vodilo računa, kako u ratu, tako i po njegovom završetku. Na to svakako ukazuju ne samo prolongiranje definisanja njenog statusa unutar Jugoslavije još u ratu i odugovlačenje sa sazivanjem Antifašističke skupštine (ASNOS-a), koje se pravdalo objektivnim, ratnim okolnostima, zatim sputavanje njene nacionalne elite da iskaže inicijativu i u tom smislu nametne svoja rešenja, kao što su to učinile ostale jugoslovenske zemlje pre i posle zasedanja AVNOJ-a u Jajcu, već i zakonodavna rešenja posle rata koja su definisala jedino Srbiju kao složenu federalnu jedinicu unutar jugoslovenske federacije. Time je jugoslovenska „federacija ravnoteže” sa slabom Srbijom dobila svoju definitivnu formu.

\footnotetext{
${ }^{125}$ Izvori za istoriju SKJ,knj. 9, str. 343-344.

${ }^{126}$ Arhiv Srbije, Fond PKS (Pokrajinski komitet KP za Srbiju), fasc. 7, dok. br. 208

${ }^{127}$ Osnivački kongres KP Srbije, 8-12. maj 1945. godine, Beograd, 1972, str. 31-43, 121-138, 192-208; Referati Blagoja Neškovića, Petra Stambolića i Mitre Mitrović.
} 
Međutim, pojedina pitanja od vitalnog interesa po Srbiju i srpski narod u njegovoj matici ostala su i dalje otvorena, izazivajući decenijama posle rata velike potrese i dobijajući posebno na aktuelnosti u vreme raspada SFRJ i ratova vođenih u poslednjoj deceniji prošlog veka. Krivicu za takvo stanje u velikoj meri snosi rukovodstvo KPJ koje se svojom politikom u toku i posle Drugog svetskog rata nije na pravi način odredilo prema srpskim nacionalnim interesima, prvenstveno u Vojvodini i na Kosovu i Metohiji. Dok je u slučaju Srema 1943. uspelo donekle da amortizuje nacionalističke pretenzije hrvatskih komunista, ostavljajući pitanje definitivnog rešavanja statusa Vojvodine unutar jugoslovenske federacije posle rata, u slučaju Kosova i Metohije rukovodstvo KPJ dozvolilo je ekstremnom albanskom nacionalizmu da poprimi razmere koje će posle rata decenijama sistematski ugrožavati egzistencijalne interese i opstanak Srba u ovoj oblasti i dovesti, na kraju, u pitanje integritet i suverenitet srpske države na ovom prostoru.

lako je teritorijalna celovitost Jugoslavije predstavljala jedan od stubova nacionalne politike KPJ u ratu, odnos komunističkog vođstva sa Josipom Brozom na čelu prema Kosovu i Metohiji, albanskom pitanju i rešavanju statusa ove oblasti unutar Srbije i Jugoslavije, kao i albanskoj iredenti koja je Kosovo i Metohiju videla u sastavu Velike Albanije u toku rata nije izlazio iz okvira načelno definisanih stavova, programskih i partijskih dokumenata praćenih odgovarajućom propagandnom retorikom. Svesna da bi ujedinjenje Albanaca sa svojom maticom, kojem su težili i albanski komunisti, neminovno vodilo ka razgradnji jugoslovenske države, otvaranju osetjjivog i složenog pitanja promene granica na Balkanu i dezintegraciji etnički veoma heterogenog balkanskog prostora, kao i ugrožavanju vitalnih interesa najbrojnijeg naroda u Jugoslaviji koji je u Kosovu i Metohiji video simbol sopstvene državnosti, KPJ je prolongirala rešenje pitanja statusa Kosova i Metohije bar do završetka rata. Nije se mogla zanemariti ni ratna situacija u Jugoslaviji 1943/44. godine u vreme strateškog okretanja NOVJ istočnim delovima zemlje, saveznička, posebno Cerčilova zainteresovanost za Jugoslaviju i Srbiju, zatim propaganda građanskih krugova u zemlji i emigraciji koja je KPJ prestavljala kao antisrpski pokret koji na srpskoj etničkoj teritoriji stvara veštačke „federalne jedinice”.

Pokušaj KPJ da vojno-politički (partijski) institucionalno integriše Kosovo i Metohiju u okviru jugoslovenskog prostora tokom rata nailazio je na opšte odbacivanje od albanskih nacionalista, albanskih komunista, pa i samog albanskog stanovništva. Odsustvo njihove podrške, separatističke ambicije Albanaca i mržnja prema srpskom narodu, Srbiji i Jugoslaviji koja je poprimala patološke razmere, presudno su uticali na posleratnu radikalizaciju dezintegracionih procesa u ovoj oblasti. Ratovi iz 90 -ih godina prošlog veka i aktivno međunarodno političko i vojno uplitanje iznedrili su uslove da u februaru 2008. godine dođe do samoproglašenja nezavisnosti ove pokrajine, pod imenom Republika Kosovo.

Sa raspadom zajedničke države devedesetih godina prošlog veka i aktuelnim stanjem na Kosovu i Metohiji, Srbi su postali najveći gubitnici. Istorija kao da se poigrala nad njihovom sudbinom: od naroda koji se, u odnosu na ostale jugoslovenske narode, može pohvaliti najdužom i najbogatijom državotvornom tradicijom, doveden je u poziciju da se i danas bori za granice i međunarodni status svoje matične države. Korene takvom stanju možemo pronaći u periodu između dva i u toku Drugog svetskog rata, u jednoj politici koja je obeležila ovaj period, a koja je, evidentno, bila antisrpska. Nastavak te politike tokom decenija koje su usledile po završetku Drugog svetskog rata i ustavna rešenja (posebno ona iz 1974. godine) koja su dovela do dezintegracije jugoslovenske federacije, zatim, nekontrolisano bujanje nacionalizama i separatizama među pojedinim jugoslovenskim narodima i njihovim elitama, doživeli su devedesetih godina svoj prepoznatljivi epilog. 
Jedan vek deli nas od stvaranja prve Jugoslavije (Kraljevine SHS), a danas smo savremenici posledica nastalih razgradnjom druge (SFRJ) i treće (SRJ) Jugoslavije, protekle u znaku krvavih etničko-verskih ratova i oštrih političkih suprotstavljanja o svrsishodnosti državnog zajedništva na ovim prostorima. Jugoslovenska integracija, koja je ispunila gotovo čitav 20. vek, doživela je potpuni neuspeh, ostavljajući nam u nasleđe brojne kontroverze i različita (najčešće protivurečna) tumačenja o smislu ujedinjenja 1918. godine. Ako unitarna i nacionalno nefunkcionalna prva (Kraljevina) Jugoslavija kao država nije imala uslova za opstanak, kako protumačiti raspad druge Jugoslavije koja je svojim federativnim ustrojstvom, posebno onim koji je pružao Ustav iz 1974. godine, predstavljala suštu suprotnost prvoj? Možda decenije posle Drugog svetskog rata nisu stvorile objektivne uslove da ideja i praksa jugoslovenskog federalizma zaživi i bude svrsishodna ili je, pak, ona bila promašena investicija kako god da se na nju gledalo, pokazaće vreme, ali je činjenica da se federacija na jugoslovenskom primeru pretvorila u svoju suprotnost. Umesto zajedništva iznedrila je nekontrolisanu mržnju koja je dovela do građanskog rata i raspada države (SFRJ).

\section{Ideje i predlozi za konfederalizaciju Jugoslavije 1945-1991. godine}

Tokom sedam decenija postojanja jugoslovenske države, u vreme velikih državnih i političkih kriza koje su pratile prvu i drugu Jugoslaviju, bilo je ideja za njihovom transformacijom: Kraljevine Jugoslavije od unitarne u federalnu državu, ${ }^{128}$ a socijalističke Jugoslavije iz federacije u konfederaciju. Predlozi konfederalizacije jugoslovenske države posle Drugog svetskog rata odnosili su se najpre na transformaciju njenog ustavnopravnog sistema (do 1990. godine), kako bi ona bila prihvatljivija zajednica za sve njene narode, da bi početkom devedesetih godina novi predlozi bili u funkciji rešavanja jugoslovenske

\footnotetext{
${ }^{128}$ Zanimljivo je kako je već krajem Prvog svetskog rata, u vreme nastajanja zajedničke jugoslavenske države, bilo razrađenih ideja o novoj Jugoslaviji kao zajednici država s određenim konfederativnim obeležjima. lako su se te ideje odnosile na definisanje prelaznog, provizornog perioda, od proglašenja ujedinjenja do donošenja ustava, one mogu ukazivati na zanimljiva rešenja konfederativnog uređenja zajedničke države koja su već tada bila u opticaju. Pobornici takvih ideja bili su, kao i kasnije, pripadnici hrvatske i slovenačke političke elite, a kao primer može poslužiti Ženevska deklaracija iz novembra 1918. godine, koju su potpisali predsednik srpske vlade Nikola Pašić i predsednik Narodnog vijeća SHS Anton Korošec, uz sudelovanje predsednika Jugoslovenskog odbora Ante Trumbića. Deklaracijom je bilo predviđeno da Država SHS i Kraljevina Srbija ostanu posebne teritorije sa zakonodavnim i upravnim funkcijama u autonomnim poslovima sve do osnivanja zajedničke vlade nove države. Ovim aktom priznata je ravnopravnost Države Slovenaca, Hrvata i Srba s Kraljevinom Srbijom pri ujedinjenju južnoslovenskih naroda u zajedničku državu, po pitanju unutrašnjeg uređenja, o čemu je trebalo da odlučuje Ustavotvorna skupština izabrana na demokratskim načelima. Utvrđeno je osnivanje zajedničke vlade, koju će činiti po tri člana iz srpske vlade i Narodnog vijeća SHS-a, a u njen delokrug ući će spoljna politika, vojska i mornarica, dok će o unutrašnjim poslovima i dalje odlučivati vlade Kraljevine Srbije i Države SHS. Time bi bila uspostavljena ravnopravnost oba dela nove države, što nije odgovaralo politici srpske vlade, pa je Nikola Pašić opozvao svoj potpis i Ženevska deklaracija nije nikada stupila na snagu, a rad na stvaranju zajedničke države preneo se na dogovor srpske vlade i Narodnog vijeća. (Tekst Ženevske deklaracije vidi: $\mathrm{Hr}$ vatska enciklopedija, izdanje Leksikografskog zavoda Miroslav Krleža, Zagreb, 1999-2009; Ferdo Šišić, Dokumenti o postanku Kraljevine Srba, Hrvata i Slovenaca, Naklada „Matica Hrvatska”, Zagreb, 1920, str. 236-241; Ferdo Čulinović, Državnopravna historija jugoslavenskih zemalja XIX i XX veka, knj. II, Školska knjiga, Zagreb, 1954, str. 207-209).
} 
krize koja je pretila raspadom države i krvavim građanskim ratom. ${ }^{129}$ Među njima se izdvajaju: 1) Zajednički hrvatsko-slovenački predlog iz oktobra 1990. godine, zatim, 2) Plan u pet tačaka (Davorina Rudolfa) iz 1991. i 3) Predlog koji je 4. novembra 1991. jugoslovenskim (novopriznatim) državama ponudila Konferencija o Jugoslaviji EZ, koji je bio i poslednja prilika za „spasavanje” zajedničke države. ${ }^{130}$

Tokom čitavog posleratnog perioda socijalistička Jugoslavija se nalazila u stalnoj opasnosti od mogućeg raspada. Unutar naočigled stabilnog i ideološki monolitnog partijskog sistema vođene su rasprave o ključnim državnim i političkim pitanjima, pa i onim koja su se ticala preuređenja jugoslovenske zajednice. Gotovo od samog početka egzistirale su razne ideje o nužnosti njene transformacije u pravcu konfederacije. U mnogim oblastima društvenog života pokazalo se da, uprkos svom federalnom sustavu, u osnovi centralistički i etatistički uređena država, kao što je bila Jugoslavija pod stalnim pritiskom i apsolutnom moći Partije i harizmatskog vođe, nameće potrebu za ozbiljnijim promenama svog državnog uređenja.

Prva zvanična ideja o stvaranju jugoslovenske konfederacije došla je od Brozovog najbližeg saradnika i jednog od glavnih komunističkih ideologa u Jugoslaviji, državnog i partijskog funkcionera Edvarda Kardelja. Na sednici Izvršnog komiteta CK SKJ, od 14. marta 1962. godine, u okolnostima oštrih ideoloških sporenja i sučeljavanja stavova koji su, na jednoj strani, zahtevali veću samostalnost republika i onih koji su pružali podršku postojećem federativnom ustrojstvu, Kardelj je tvrdio da je moguće izvršiti konfederalizaciju jugoslovenske države, bez obzira na ideološke imperative. U svom predlogu konfederalizacije državnog i društvenog sistema, Kardelj je posebno naglasio potrebu za decentralizacijom finansijskih mehanizama, ukazujući na nužnost razdvajanja nadležnosti federalnih banaka od republičkih. Po njemu, efikasnost banaka treba da se meri isključivo njihovim profitom. Smatrao je da bi novi devizni režim i novi finansijski standardi, uz najnužnije promene državnopravnog sistema, trebalo da stabilizuju jugoslovensku državu. Međutim, kako je u to vreme vladala velika napetost u odnosima republičkih partijskih struktura, bio je svestan objektivnih opasnosti po opstanak državne zajednice.

\footnotetext{
${ }^{129}$ Državni savez (konfederacija), po definiciji, jeste savez više država zasnovan na međunarodnom ugovoru radi ostvarivanja nekog zajedničkog interesa. U okvirima ovakve državne zajednice, članice saveza su međunarodnopravni subjekti, sa velikim obimom poslova iz njihove nadležnosti. lako je ovaj pojam u pravnoj teoriji imao svoju genezu, jer je izraz „konfederacija” bio različito tumačen u prošlosti, danas ipak postoji načelno usaglašeno mišljenje o shvatanju konfederacije. U savremenom međunarodnom iskustvu ne postoje primeri tako ustanovljenih složenih država. Možda bi se, kao najnoviji primer tako uređene države, mogla pomenuti Zajednica Nezavisnih Država, nastala kao vid zajedništva pojedinih država, bivših republika SSSR-a. ZND je formirana u Alma Ati 21. decembra 1992. godine, kao rezultat želje za međusobnom saradnjom 12 država nastalih raspadom SSSR-a. Švajcarska konfederacija (formirana 1291. godine) svakako je jedan od najstarijih primera konfederacije $u$ istoriji i najjasniji uzor njenog organiziranja, a jedan od prvih celovitih primera ko-nfederativnog uređenja je period američke istorije od 1777. do Ustava iz 1787 . godine, u kojem je nastao prvi savremeni model konfederacije.

$\mathrm{U}$ istoriji je bilo, ali i danas postoje, i drugi oblici povezivanja država, utemeljenih na različitim međusobnim, ali i međunarodnim interesima. Oni su nesporno subjekti međunarodnog prava, od klasičnih struktura, kao npr. Ujedinjeni narodi, do one „supranacionalne”, kao što je Evropska unija. Svu osobnost ispoljavanja najrazličitijih kompromisa predstavljaju i savremeni primeri složenih država sui generis, kao što je Bosna i Hercegovina, prema Dejtonskom sporazumu iz 1995, te zajednička država Srbije i Crne Gore, u skladu sa odredbama tzv. Be-ogradskog sporazuma i s njim usklađene Ustavne povelje iz 2002. godine.

${ }^{130}$ Budislav Vukas, Prijedlozi i nacrti konfederalizacije Jugoslavije 1990/91. - posljednji pokušaji „spašavanja” zajedničke države, Zbornik Pravnog fakulteta Sveučilišta u Rijeci, v. 27, br. 2, 2006, str. 761-803.
} 
U periodu dinamičnih političkih odnosa šezdesetih godina, kada je jugoslovenska država realno bila ugrožena pojavom ekstremnih nacionalnih pokreta, među kojima je najglasniji bio Hrvatski nacionalni pokret („Maspok”/,Masovni pokret”, ili, „Hrvatsko proljeće” 1970/71), razmišljanja o preuređenju Jugoslavije postaju nužnost i povod za definisanje novih ustavnopravnih rešenja koja će omogućiti njenu reorganizaciju. Jedna od glavnih intencija političara koji su pripadali ekstremnoj grupaciji hrvatskih nacionalista (maspokovaca), a koji su uživali podršku velikog dela hrvatskih komunista, političkog vrha Republike Hrvatske i ustaške emigracije na Zapadu, bio je preobražaj Jugoslavije od savezne države u savez država. Vođstvo hrvatskih komunista, većim delom okupljeno oko ove ideje, obrazlažući potrebu za transformacijom jugoslovenske države, predlagalo je i konkretna rešenja za njenu reformu. Kao razloge navodilo je opšte političke prilike, stanje u državnom uređenju, ustavnom i pravnom sistemu, a pre svega potrebu da se reafirmiše hrvatska država u svom punom kapacitetu, onakvom, kako navode pojedini autori, kakav je imala kao kraljevina u srednjem veku. ${ }^{131}$

Transformacija položaja Hrvatske, odnosno promena njenog statusa u federaciji podrazumevala je i institucionalnu transformaciju jugoslovenske države prema konfederalnom modelu, modelu saveza suverenih država, koji je temeljno obrazlagan u aktima Centralnog komiteta SKH, uz pozivanje čak na izvorne principe ZAVNOH-a iz ratnog perioda. Konkretno, vođstvo hrvatskih komunista predlagalo je ekonomsku decentralizaciju, deetatizaciju velikih državnih preduzeća, te radikalne promene u funkcionisanju pravnih i faktičkih mehanizama u Jugoslaviji (npr. reforma deviznog sistema, ekonomskog koncepta, „politike čistih računa”, zatim savezne politike prema tzv. nerazvijenim republikama, eksploataciji državnih dobitaka od turizma i sl). ${ }^{132}$

Maspok je ugušen krajem 1971. godine, nakon 21. sednice Predsedništva SKJ održane u Karađorđevu 30. novembra/1. decembra, na kojoj je ovaj pokret formalno osuđen kao šovinistički i tom prilikom je izvršena smena vođstva SK Hrvatske. U decembru 1971. pohapšeni su mnogi studentski aktivisti, a neki su osuđeni na višegodišnji zatvor. Zbog sudelovanja u pokretu uhapšeno je i osuđeno više od 2.000 ljudi u Hrvatskoj. Vodeći hrvatski komunisti Savka Dabčević-Kučar i Mika Tripalo smenjeni su sa svojih državnih i partijskih položaja, a mnogi aktivisti i vođe Maspoka uhapšeni su i pozatvarani. U toj grupi bio je i . Ono što će ovaj pokret ostaviti kao trajno nasleđe ideji konfederalizacije, a zatim i razgradnje Jugoslavije, jeste ustupak koji je Josip Broz učinio hrvatskom nacionalizmu. Dozvolio je promenu Ustava SFRJ 1974. godine, kojim je formalno i faktički konfederalizovana savezna država, a republikama dato pravo veta na njegove dalje izmene. Ustav iz 1974. godine izazvao je veliko nezadovoljstvo srpskog naroda u čitavoj SFRJ. ${ }^{133}$

Iskoristivši Maspok u Hrvatskoj, kao izgovor za gušenje liberalnih zahteva za demokratizacijom SFRJ, Broz je iz jugoslovenskog političkog života 1972. godine odstranio i srpske komuniste Marka Nikezića i Latinku Perović, Slovenca Staneta Kavčiča i Makedonca Krstu Crvenkovskog. Pokazalo se da su za vladavinu doživotnog pred-

\footnotetext{
${ }^{131}$ Ana S. Trbovich, A legal geography of Yugoslavia's disintegration, Oxford Univ Press. 2008, str. 162.

${ }^{132}$ Savka Dabčević Kučar, "71 - Hrvatski snovi i stvarnost - knjiga prva i druga, Interpublic, Zagreb, 1997; Mika Tripalo, Hrvatsko proljeće, Globus, Zagreb, 1990; M. Dragović, Hrvatsko proljeće - masovni pokret hrvatskog naroda, Hrvatska obzorja, časopis Ogranka Matice hrvatske Split, 1996, 4, str. 781-790. (časopis je u celosti tematski posvećen Hrvatskom proljeću).

${ }^{133}$ Momčilo Diklić, Srbi u Hrvatskoj 1945-1991: period potiranja nacionalnog identiteta, Institut za evropske studije, Beograd, 2007, str. 109-112.
} 
sednika SFRJ bili opasniji prosvećeni liberali i potvrđeni nenacionalisti (poput Nikezića i Latinke Perović), nego ekstremni hrvatski nacionalizam. Srpski liberali uklonjeni su radi uspostavljanja ravnoteže posle uklanjanja hrvatskih maspokovaca, a delom što je njihova politika previše naginjala „zapadnjaštvu” i što su svojim viđenjima reformi, navodno, ugrožavali neprikosnovenu vlast Josipa Броза. ${ }^{134}$

Direktna posledica čistke liberala bilo je uklanjanje oko 6.000 ljudi, mahom direktora i novonastale „menadžerske klase”, što je zakočilo privredni razvoj zemlje. Da bi umirio hrvatske nacionaliste, Broz se okomio na srpsku inteligenciju koja je ukazivala na podređen položaj srpskog naroda u Jugoslaviji. Pitanja koja su postavljali Dobrica Ćosić i akademik Mihailo Đurić (zašto je data autonomija Albancima na Kosovu, a Srbi u Hrvatskoj nemaju autonomiju, zašto je Vojvodina autonomna i pored toga što su Srbi većinsko stanovništvo u njoj i dr.), dovela su do njihove političke diskreditacije, pa i sudskih progona. Profesor Đurić je, povodom rasprave o ustavnim amandmanima u martu 1971. godine, odstranjen sa Pravnog fakulteta i presudom Okružnog suda u Beogradu, 17. jula 1972. godine, osuđen na kaznu strogog zatvora u trajanju od dve godine zbog krivičnog dela neprijateljske propagande, koja je kasnije preinačena u kaznu zatvora od devet meseci. U svom izlaganju na sastanku Sekcije udruženja univerzitetskih nastavnika, održanom 18. marta 1971. godine, na Pravnom fakultetu u Beogradu, objavljenom u listu Student iste godine pod nazivom „Smišljene smutnje”, zatim u časopisu Anali Pravnog fakuIteta u Beogradu 3/1971, profesor Đurić je upozoravao na Maspokove eskalacije hrvatskog nacionalizma i secesionizma, ukazao da je tadašnja situacija u Jugoslaviji nepovoljna za Srbiju, ne samo zbog toga što je Srbija nemilosrdno i nepravedno bila optuživana zbog centralizma i unitarizma u prošlosti, nego i zbog toga što joj je zabranjeno da postavlja pitanje odgovornosti onih koji su počinili genocid nad srpskim narodom. On je, takođe, upozorio da granice SR Srbije nisu nacionalne niti istorijske granice srpskog

\footnotetext{
${ }^{134}$ Razgovori između Nikezića i Tita iz vremena koje je prethodilo njegovoj smeni, svedoče da je geneza sukoba i nerazumevanja između njih dvojice išla „polako, ali postojano”. Nikezić je početkom 1971. godine u razgovoru o Kosovu rekao Titu da „što se tiče Kosova, Srbija ima jak stomak, pa može da svari i to da Kosovo bude republika, i ako svi u Jugoslaviji misle da tako treba da bude, neka bude, ali morate računati da će se Srbija 'dezangažovati', a da će Beograd da stane u zaštitu manjina na Kosovu". U maju iste godine na zvaničnom sastanku kod Tita, Nikezić je rekao: „Srbija ne može prihvatiti da bude manje samostalna od drugih, a izgleda da bi se to želelo".

Na četvorodnevnom sastanku Tita i „rukovodećeg društvenopolitičkog aktiva Srbije” u jesen 1972. godine, Tito im je poručio da omalovažavaju borbu protiv anarholiberalizma i klasnog neprijatelja, da su kriterijumi borbe protiv klasnog neprijatelja u Srbiji liberalniji, da pojam socijalističke demokratije dobija premise građanske demokratije. Prigovoreno im je i što je marksizam skoro iščezao iz nastavnih programa univerziteta. Jedan od savremenika kasnije je govorio: „Posle smene Nikezića kod Tita se više nije išlo na razgovor, već na referisanje”.

Liberali su se mirno povukli - Marko Nikezić kao predsedenik i Latinka Perović kao sekretar CK. Nisu se bunili, niti „talasali”. Nikezić je kasnije, kako se pisalo, delovao „bezvoljno” na tom sastanku: „Za mene je taj sastanak bio čista formalnost. Jesam bio flegmatičan. Zašto bih ja Titu objašnjavao našu politiku, kad on o tome dovoljno zna? Takođe, organski nisam mogao da budem samokritičan. Smešno je da zreo čovek kaže: ja sam se juče prevario..." Iz solidarnosti prema liberalima, i Koča Popović se (po drugi put) povukao iz politike i gotovo svi oni koji su mislili da je vreme za istinsko otvaranje Jugoslavije prema svetu. Tito je tako, u svojoj „šizofrenoj” fazi vladavine, posle svesrdnog podržavanja hrvatskih maspokovaca i obračuna sa njima, „počistio” i neistomišljenike u Srbiji i vratio staljinizam na velika vrata u Jugoslaviju. Obračun sa liberalima ispraćen je njegovim rečima u intervjuu za „Vjesnik”, dan uoči poslednjeg sastanka: „Vraćamo se nazad tamo gdje smo griješili, gdje smo pustili da se ode predaleko" i „ne možemo dozvoliti da se demokratijom koristi svako” (,Slom srpskih liberala: Događaji koji su menjali Srbiju", Nedeljnik, feljton, 6. februar 2018. godine).
} 
naroda, kao ni u slučaju ostalih jugoslovenskih republika i da one imaju uslovno značenje, da su više administrativnog, nego političkog kataktera. Neodrživost i proizvoljnost tih granica, po njemu, postaje očigledna onda kada se one shvate kao granice nacionalnih država. ${ }^{135}$ Sudski proces i presuda profesoru Mihailu Đuriću bili su, zapravo, deo politike ravnoteže Brozovog režima u vreme kada je Maspok kulminirao u Hrvatskoj i kada su se mnogi Maspokovci našli u zatvoru.

Kako bi umirio hrvatske nacionaliste, Broz je njihove zahteve „upakovao” u nacrt Ustava iz 1974. godine, koji će za krajnju posledicu imati paralizovanje federalne, na račun jačanja republičke vlasti. Nastao kao rezultat kompromisa i velikih ustupaka nacionalnim elitama u pojedinim jugoslovenskim republikama, ustav je izvršio značajne promene u državnom ustrojstvu SFRJ i društveno-ekonomskom uređenju zemlje, koje su kasnije korišćene kao pravni temelj za proces raspada savezne države i različito tumačenje od strane zaraćenih strana u građanskom ratu 1991-1995. godine. Na taj način postao je okosnica budućeg secesionizma. ${ }^{136}$

Ustav će jugoslovenskim republikama, posebno pokrajinama unutar SR Srbije - Vojvodini i Kosovu i Metohiji, dati široka prava i ovlašćenja. Pokrajine su dobile svoja državna i partijska predsedništva, kao i republike, njihova teritorija nije se mogla menjati bez odluke pokrajinske skupštine, a pokrajinske vlasti su, pored ostalog, dobile i pravo veta na odluke koje bi donosila Republika Srbija, pa čak i one koje su se ticale isključivo užeg područja Srbije. Ovakvo „razvlašćivanje” Republike Srbije dovodilo ju je ne samo u neravnopravan položaj u odnosu na ostale jugoslovenske republike, već i u niz apsurdnih situacija, da republička vlast nije mogla u punom kapacitetu funkcionisati ne samo na teritoriji pokrajina, već i u onom delu koji se kolokvijalno nazivao „užom Srbijom”, a koji je u pogledu zakonodavne i izvršne vlasti bio u neravnopravnom položaju prema pokraji-nama.

Usvajanju Ustava prethodili su politički događaji koji su, na neki način, najavili početak konfederalizacije zemlje. Najpre je u leto 1966. godine, posle montiranog procesa o prisluškivanju, sa svih funkcija smenjen Aleksandar Ranković, jedan od najbližih saradnika Josipa Broza Tita koji je bio protivnik slabljenja federacije. Time je pobedila struja koju je predvodio Edvard Kardelj, što će otvoriti vrata procesu konfederalizacije zemlje. Godine 1968. i 1971. usvojeni su amandmani na tadašnji savezni Ustav, kojima je (1971) znatno sužen obim prava i dužnosti federacije u korist federalnih jedinica i uvedeno Predsedništvo SFRJ kao kolektivni organ rukovođenja. Nakon smene kompletnog rukovodstva Hrvatske i kadrovske čistke u rukovodstvu Srbije (1971/72), sve je bilo spremno za donošenje novog saveznog Ustava.

Ustavna rešenja iz 1974. godine i njihova implementacija ukazivala su na značajne elemente konfederalizacije Jugoslavije. lako nije predstavljao međunarodni ugovor (kako se po proceduri usvajaju takvi ustavi), Ustav je usvojen po paritetnom principu, baš kao i mnogi savezni zakoni koji su bili u nadležnosti federacije. Na osnovu njegovih odredbi, republike su dobile značajne prerogative državnosti koje su, pre svega, bile vidljive u njihovom, iako ograničenom, međunarodnopravnom subjektivitetu. Republički ustavi su davali republikama pravo učešća u procesu kreiranja spoljne politike SFRJ, dok su u proce-

\footnotetext{
${ }^{135}$ Pečat, List slobiodne Srbije, dokumenti, 1. decembar 2011. godine.

${ }^{136}$ Dejan Jović, Yugoslavia: A State that Withered Away (Jugoslavija: država koja je odumrla u papiru), Purdue University Press, 2009. str. 32.
} 
su ratifikacije međunarodnih ugovora predviđali mogućnost da republike daju saglasnost na one ugovore za koje republička vlast ima izvršnu nadležnost. U okviru predviđenog zakonodavnog postupka i nadležnosti federacije, republike su davale saglasnost na međunarodne ugovore koji spadaju u njihovu nadležnost, a imale su i mogućnost učestvovanja u međunarodnim odnosima, te ostvarivanju međunarodne saradnje. Ustavom iz 1974. godine rasformirani su mnogi fondovi federacije i preneti u nadležnost republika, a federativni organi su ustrojeni na principima pariteta, a ne više na većinskom modelu.

Tokom javne rasprave o ustavnim amandmanima 1971. godine, koje će rezultirati donošenjem novog ustava 1974, dr je upozoravao da će Jugoslavija takvim ustavom postati samo geografski pojam na čijem će tlu, pod maskom doslednog negovanja ravnopravnosti između naroda, biti uspostavljeno nekoliko nezavisnih, čak i međusobno suprotstavljenih nacionalnih država. Tvrdio je da predložena ustavna promena ne samo što iz osnova menja karakter dosadašnje državne zajednice jugoslovenskih naroda, već odbacuje i samu njenu ideju i slutio da, ukoliko nešto još od nje i ostane, „to je samo zato da bismo u sledećoj fazi promena imali šta da privedemo kraju". ${ }^{137}$

Najviše primedbi na Ustav iz 1974. godine imala je Republika Srbija, što je bilo i prirodno, imajući u vidu da je ona u njegovim rešenjima imala i najviše štete. U početku, tražilo se od saveznih vlasti da ubede pokrajine da ispravno interpretiraju Ustav, po kojem je Srbija ipak bila suverena republika sa odgovarajućim stepenom autonomije za svoje pokrajine. Međutim, nakon Kardeljeve (1979) i Titove smrti (1980), sve teže je i komplikovanije bilo arbitrirati u sporovima između Republike Srbije i njenih pokrajina. Sredinom 80-ih godina srpsko rukovodstvo je insistiralo na promeni Ustava, a ne samo na njegovoj ispravnoj interpretaciji. Početkom 1987. godine, zahvaljujući njegovim nastojanjima, Predsedništvo SFRJ je iniciralo usvajanje više od 130 amandmana. Međutim, nešto kasnije došlo je do obračuna unutar srpskog rukovodstva. Na Osmoj sednici CK SK Srbije, septembra 1987. godine, pobedila je struja Slobodana Miloševića koja je energično i oštro zahtevala raskid sa Ustavom iz 1974. godine. Tako će krajem 1988. doći do smene rukovodstava u obema pokrajinama, a u proleće 1989. godine usvojeni su i amandmani na Ustav Srbije, koji su znatno suzili ovlašćenja i prava pokrajina. Konačan raskid sa ustavnim rešenjima iz 1974. godine u Srbiji desio se septembra 1990. godine, kada je njena Skupština usvojila novi Ustav Republike Srbije.

U međuvremenu, i ostale jugoslovenske republike otpočele su proceduru raskida sa Ustavom iz 1974. godine. Slovenija je u martu 1990. najpre uklonila iz naziva republike prefiks „socijalistička” i istovremeno usvojila niz amandmana na sopstveni ustav koji su najavili raskid sa socijalističkim uređenjem. Hrvatska je, nakon pobede HDZ-a i Franje Tuđmana na izborima, u leto 1990. godine usvojila amandmane kojima je takođe izbacila prefiks „socijalistička” i izmenila republičke simbole, a u decembru 1990. usvojila novi republički ustav. Bosna i Hercegovina i Makedonija su u jesen 1990, nakon što su pobedile antikomunističke snage u ovim republikama, takođe raskinule sa socijalističkim sistemom, a u Crnoj Gori je raskid formalno označen donošenjem novog republičkog ustava u jesen 1992. godine.

Uporedo sa ustavnom „tematikom”, sedamdesete i osamdesete godine obeležile su brojne tenzije u međunacionalnim odnosima i novi ideološki „trendovi”. Razvlašćena sa-

${ }^{137}$ Mihailo Đurić, „Smišljene smutnje”, Anali Pravnog fakulteta u Beogradu, 3/1971, str. 230—233. 
vezna država nije bila dovoljna mera da se „nahrane” rastući nacionalizmi koji su bujali, naročito u zapadnim jugoslovenskim republikama i na Kosovu i Metohiji. Smrt jugoslovenskog predsednika 1980. godine biće uvod u sve intenzivnije i otvorenije međunacionalne sukobe u Jugoslaviji. Godine 1981. ponovo eskalira kosovska kriza koja će u narednim godinama dosegnuti velike razmere. Pojava Memoranduma SANU 1986. godine razbuktala je nacionalističke strasti do usijanja u čitavoj zemlji, a ovaj dokument poslužiće jugoslovenskim republikama kao idejni predložak za navodno ponovno rađanje velikosrpske ideje i ispoljavanje velikosrpske agresije prema pojedinim jugoslovenskim republikama 1991/92. godine. Ukidanje autonomnih prava pokrajinama u Srbiji 1988. godine pripisali su Slobodanu Miloševiću ostali republički lideri kao čin samoinicijativnog rušenja jugoslovenskog ustavnog sistema. Godine 1990. raspao se i Savez komunista Jugoslavije. Pojavljuju se nove političke stranke koje su iznedrile nacionalne političke elite i lidere koji će iskoristiti prve višestranačke izbore (1990) u svojim republikama da se pripreme za završni čin rasturanja zajedničke države.

U predvečerje velike krize, kada je već bilo jasno da se odvijaju burne promene na jugoslavenskom političkom horizontu koje su lako mogle da dovedu i do ratnog raspleta, pojedini intelektualci i političari iz zapadnih republika počinju otvoreno da govore o neophodnosti transformacije jugoslovenske države u pravcu stvaranja klasičnog modela konfederacije. Po tom pitanju najpre se oglašava slovenačko javno mnjenje opozicione orijentacije, naglašavajući potrebu reforme jugoslovenske države. Oko ove ideje polarizuju se dve grupe - jedna okupljena oko lista "Mladina” i Janeza Janše, dok se duga, intelektualno snažnija, vezuje za časopis „Nova revija” Grafenauera i Dimitrija Rupela. Druga grupa je ponudila više opcija za Sloveniju, od njenog ostanka u Jugoslaviji, uz uslov ozbiljnijih reformi jugoslovenske federacije i stvaranja konfederacije, pa sve do stvaranja potpuno nezavisne i samostalne države. ${ }^{138}$

Sa slomom SK u Sloveniji i demokratizacijom slovenačkog društva (posle prvih višepartijskih izbora), u novim političkim zaokretima ideja samostalne slovenačke države postepeno odnosi prevagu. U Hrvatskoj su sličnu struju predvodili najpre vođa hrvatske opozicione misli Franjo Tuđman (1989. godine je osnovao Hrvatsku demokratsku zajednicu - HDZ i postao je njen predsednik) i predsednik HAZU Ivan Supek. lako različitih političkih vizija, u svojim predavanjima u Čikagu, novembra 1989. godine, oni su se izjašnjavali za transformaciju jugoslovenske države u pravcu konfederacije. ${ }^{139}$ Gotovo je nemoguće tvrditi da je na početku postojala bilo kakva veza i razumevanje slovenačkih krugova za pitanja hrvatskih državotvornih interesa, iako će nova realnost 1990. godine (nakon pobede na prvim višepartijskim izborima) iznedriti zajedničku, koordiniranu aktivnost slovenačke i hrvatske vlade oko ovako važnog pitanja.

Ubrzo po obrazovanju novih vlada u Zagrebu i Ljubljani 1990. godine, intenziviraju se rasprave o reorganizaciji jugoslovenske države, pri čemu se naglašava da se ona može spasiti samo kao savez suverenih država, a pojavljuju se i prvi službeni nacrti mogućeg

\footnotetext{
${ }^{138}$ Dejan Jović, Jugoslavija - država koja je odumrla - uspon, kriza i pad Kardeljeve Jugoslavije (1974-1990), Prometej, Zagreb, 2003, str. 433.

${ }^{139}$ Ivan Supek je svoju tezu o stvaranju konfederalnog modela država obrazlagao u mnogim radovima, predavanjima i intervjuima hrvatskim medijima, zalažući se za jačanje institucija društvenog, političkog i ekonomskog karaktera, čime će se postići pluralitet i demokratičnost društva, dok se Tuđman, na drugoj strani, priklanjao naglašenoj nacionalno-liberalnoj orijentaciji, stvaranjem jake nacionalne države hrvatskog naroda.
} 
saveza jugoslovenskih republika. ${ }^{140}$ Među njima posebno se ističe Zajednički slovenskohrvatski nacrt iz oktobra 1990. godine ${ }^{141}$ koji je nastao na osnovu dva odvojena nacrta: hrvatskog nacrta Ugovora o jugoslovenskoj konfederaciji - savezu jugoslovenskih republika, utemeljenoj na međunarodnom ugovoru i slovenačkog predloga ugovora od 11. septembra, koji je nudio labaviji savez (tzv. konfederaciju a la carte ${ }^{142}$ ). Zajednički predlog, koji je bio bliži hrvatskom stanovištu, bio je inspirisan idejom tadašnjeg ustrojstva Evropske zajednice, kao i istorijskim iskustvima konfederativno uređenih država, a na drugoj strani potrebom da se ostvari kompromis između oprečnih stanovišta tadašnjih jugoslovenskih republika (pre svega, sa onima koji su se zalagali za očuvanje federativnog ustrojstva države, uz određene korekcije) i očuva mir i stabilnost u regionu.

Prema autoru ovog predloga (profesoru Vladimiru Deganu) radilo se o „dosta čvrstom i homogenizovanom savezu, sa mnogim zajedničkim poljima saradnje i mehanizmima njenog sprovođenja". Saradnja koja bi se ostvarivala preko Saveza država obuhvatala je: 1) vojno-odbrambenu saradnju: 2) saradnju u promociji standarda zaštite prava čoveka i nacionalnih manjina i 3) ekonomsku, carinsku saradnju, zaštitu okoline i kulturno-naučnu suradnju, prema principima međudržavne solidarnosti. Temeljno polazište Zajedničkog predloga jeste da „Konfederacija mora osigurati ostvarivanje odbrambeno-sigurnosnih interesa, tj. zaštitu od napada izvana, preciznije, zaštitu granica svih država članica". Posebno je naglašena zajednička odbrana od agresije na konfederaciju, gde su nadležnosti i postupak vođenja odbrambenih zadataka povereni zajedničkim civilnim i vojnim telima konfederacije, ostavljajući državama članicama široku autonomiju u organizaciji, funkcionisanju, naročito komandovanju sopstvenim vojnim snagama. Ova klauzula bila je zasnovana na iskustvima NATO-a, koji je u čl. 5. Severnoatlantskog ugovora iz 1949. godine sadržao suštinu vojnog postojanja tog vojno-političkog saveza. U pitanju je bila odredba o zajedničkoj odbrani od agresije, koja smatra napad na bilo koju od država članica saveza napadom na čitav savez. ${ }^{43}$ Ekonomska saradnja, po ovom zajedničkom predlogu, sastojala bi se od formiranja zajedničkih mehanizama i sadržaja iz sledećih oblasti: a) carinske unije, b) zajedničkog tržišta, v) monetarne unije i g) zaštite okoline i ostalih vidova saradnje. Međutim, nijedna od pomenutih oblasti nije bila precizno definisana ovim nacrtom.

Kada je reč o zajedničkim državnim institucijama, hrvatsko-slovenački nacrt jugoslavenske konfederacije polazio je od tetrarhijskog (četvornog) koncepta glavnih organa ka-

\footnotetext{
${ }^{140} \mathrm{U}$ isto vreme, u Evropi se dešavaju: pad Berlinskog zida, raspad SSSR-a i urušavanje komunističkih sistema, praćeni korenitim demokratskim promenama u većini istočnoevropskih i srednjoevropskih država, ujedinjenje Nemačke, što će sve zajedno uticati i na događaje u Jugoslaviji.

${ }^{141}$ Tekst ovog nacrta objavljen je 12. oktobra u Vjesniku; Vladimir Đuro Degan, Hrvatska država u međunarodnoj zajednici, „Razvitak njezine međunarodnopravne osobnosti tijekom povijesti”, Zagreb, 2002, str. 281-294.

${ }^{142}$ Slovenački predlog je, u stvari, zagovarao bilateralne ugovore država članica, utemeljene na zajedničkim principima, na osnovu kojih države potpuno slobodno biraju sadržaje svoje međusobne saradnje, sa mogućim koordinacionim telima kroz koje bi ostvarile takvu saradnju. O tom naglašenom suverenističkom stavu i nesklonosti Slovenije prema konfederalizaciji jugoslavenske države piše i Dimitrije Rupel (Skrivnost države, Ljubljana, 1992, str. 70).

${ }^{143}$ Navedeno prema: Ivica Kinder, Institucionalna struktura i pravni položaj Severnoatlantske organizacije, Zbornik Pravnog fakulteta Rijeka, vol. 19, br. 1, Rijeka, 1998, str. 262; Zajednička odbrana bila je jedna od glavnih razloga za uspostavljanje konfederacije u istoriji. Najbolji je primer Švajcarske konfederacije, osnovane u kasnom srednjem veku, a povod je bio odbrana od Habsburgovaca i Svetog rimskog carstva. Kasnije je jedan od osnovnih zadataka Konfederacije bila zajednička odbrana kantona od trećih država. Od Bečkog kongresa 1815. godine Švajcarska nije ratovala.
} 
kvi su već, u procesima geneze evropskih integracija, postojali na nivou Evropske zajednice. On navodi Savetodavni parlament, Veće ministara, Izvršnu komisiju i Konfederalni sud. Teško je izvršiti bilo kakvu detaljniju analizu njihove pravne strukture ili mehanizama, jer je Zajednički nacrt sadržao samo osnovne principe i dosta nedorečenosti u pogledu zakonodavne i izvršne vlasti konfederalne države.

Kada je ovaj nacrt upućen Predsedništvu SFRJ u oktobru 1990. godine na razmatranje i usvajanje, većina njegovih članova nije bila sklona hrvatsko-slovenačkom modelu konfederacije. Srbija i Crna Gora su se založile za federativni model (reformisanu federaciju), dok su se Bosna i Hercegovina i Makedonija, u velikoj meri neodlučne, opredelile ipak za neku formu „egzistirajuće” federacije. Tadašnji predsednik SFRJ Borisav Jović u svojim memoarima je zapisao kako je na sednicama Predsedništva uspeo da pridobije bosansko-hercegovačku i makedonsku stranu, te predstavi njihove predloge kao „alternativu” postojećem federativnom uređenju Jugoslavije, „hvaleći” se kako je izolovao Hrvatsku i Sloveniju. ${ }^{144} \mathrm{U}$ postojećim političkim okolnostima nije bilo realno očekivati bilo kakav uspeh hrvatsko-slovenačkog nacrta. Uz optužbe na račun hrvatskog državnog vrha, vlasti u Srbiji su u isto vreme plasirale tezu kako konfederacija i nije hrvatski interes već samo pokušaj da se kroz odbijanje takvih predloga od strane srpskih i ,jugofilskih" struktura, pokaže kako nijedan pokušaj reforme jugoslovenske države nije moguć, što bi zapravo otvorilo put punoj državnoj nezavisnosti. Srpski argumenti svodili su se na optužbe kako Hrvatska želi rat protiv Srbije i priprema se za njega.

U takvoj situaciji, Hrvatski sabor je 21. februara 1991. godine usvojio Rezoluciju o prihvatanju postupka za razdruživanje SFRJ i o mogućem udruživanju Republike Hrvatske u savez suverenih država. Pretpostavka ulasku Hrvatske u bilo kakve konfederalne ili slične asocijacije bilo je priznanje njenog međunarodnog subjektiviteta, dakle, pune državnosti i samostalnosti. Rezolucija je prihvatila inicijativu Skupštine Republike Slovenije o početku procesa razdruživanja i eventualnog postizanja novog dogovora jugoslavenskih republika o stvaranju konfederativnog saveza, ovoga puta između suverenih država. Kao krajnji rok za okončanje postupka razdruživanja SFRJ predviđen je 30. juni 1991. godine. I kasnija odluka Sabora RH, od 8. oktobra 1991. godine, kojom su raskinute sve državnopravne veze Hrvatske sa republikama SFRJ i samom federacijom, takođe je ostavila mogućnost pristupanja Hrvatske savezu samostalnih i suverenih država ukoliko do njega dođe.

Raspad Jugoslavije počeo je formalno 25. juna 1991. godine. Tog dana slovenački i hrvatski parlament doneli su odluku o proglašenju nezavisnosti ovih dveju republika. Dva dana kasnije jedinice Jugoslovenske narodne armije upućene su u Sloveniju, u nameri da zaštite suverenitet i integritet jugoslovenske države. Došlo je do sukoba između pripadnika JNA i slovenačkih teritorijalaca. Prilikom opsade vojnih baza JNA u Sloveniji, slovenački teritorijalci su napali regularnu vojsku, što je rezultiralo pogibijom 40 vojnika koji su se nalazili na odsluženju redovnog vojnog roka. Posle ovih krvavih incidenata Predsedništvo SFRJ je donelo odluku o povlačenju pripadnika armije iz Slovenije.

Početkom 1991. godine otpočinju i sukobi između Srba i Hrvata u Hrvatskoj. U proleće te godine rat se sve više razbuktavao. Vode se žestoki okršaji oko Borovog Sela, koji su otpočeli 2. maja 1991. godine. Hrvatska je posle Borovog Sela pojačala antisrpsku i antijugoslovensku kampanju: „Srbočetnička JNA” i „Srboslavija” postale su najčešće reči u politič-

${ }^{144}$ Borisav Jović, Poslednje dani SFRJ, drugo izdanje, Beograd, 1996, str. 203. 
kom žargonu Hrvatske. U avgustu i septembru iste godine u Hrvatskoj se razbuktao pravi rat između Srba i JNA na jednoj, i novoformirane hrvatske vojske, na drugoj strani. Nakon oduzimanja statusa državotvornog (konstitutivnog) naroda u novom hrvatskom Ustavu (decembra 1990. godine), Srbi u Hrvatskoj su se samoorganizovali kako bi zaštitili svoja legitimna prava i živote. Tako je došlo do formiranja Republike Srpske Krajine 1991. godine. Najžešće borbe vođene su oko Vukovara, gde su trajale do novembra 1991, kada su pripadnici JNA i srpske paravojne formacije slomili hrvatski otpor i ušli u ovaj grad.

U ovakvim uslovima, u julu 1991. godine, nastao je i novi nacrt o konfederalnom udruživanju jugoslovenskih republika, a izradio ga je akademik Davorin Rudolf, ministar u hrvatskoj vladi. Zahvaljujući temeljnim i vrlo širokim znanjima o iskustvima konfederalizma kroz istoriju i dobrom poznavanju međunarodnog prava, Rudolf je izradio nacrt modela državne zajednice poznat pod imenom Plan u pet tačaka. U njemu se najpre rukovodio potrebom da se ostvari kompromis između tzv. „rigidnog” stava srpske politike i imperativa zaštite hrvatskih nacionalnih interesa, čij je cilj bio da se spreči dalje rasplamsavanje ratnog sukoba u Jugoslaviji.

Kao šef hrvatske diplomatije, Rudolf je iskoristio svoj položaj za međunarodnu promociju sopstvenog predloga, koji će vrlo brzo postati i službeni stav hrvatske vlade, iza kojeg je stao lično Franjo Tuđman. Okosnicu samog plana predstavljalo je pet tačaka: 1) priznanje odluke o samostalnosti; 2) poštovanje međunarodnih obaveza (naročito načela o mirnom rešavanju sporova); 3) Otpočinjanje postupka razdruživanja; 4) Stvaranje saveza suverenih država i 5) Poštovanje ljudskih i manjinskih prava.

U odnosu na prvu tačku, Plan je polazio od uvažavanja novih okolnosti i kao prvi, osnovni uslov, zahtevao od država članica SFRJ da priznaju odluke o samostalnosti Republika Hrvatske i Slovenije od 25. juna, što je bila osnovna pretpostavka daljih pregovora o preuređenju jugoslavenske države. To je podrazumevalo priznanje punog međunarodnopravnog subjektiviteta državama koje su proglasile samostalnost, a pozvane su i ostale države da učine istovetan korak. Što se tiče druge tačke koja se odnosila na poštovanje međunarodnih obaveza, naročito načela o mirnom rešavanju sporova, ona je anticipirala stanje koje će ubrzo postati realnost. Naime, nakon evolucije i internacionalizacije krize u Jugoslaviji, njeno rešavanje biće nezamislivo bez korišćenja modaliteta institucija međunarodnih foruma o mirnom rešavanju sporova (Veće sigurnosti UN) i međunarodnog pravosuđa (Međunarodni sud pravde). Veće sigurnosti će radi ispunjenja svojih zadataka, a to je očuvanje mira u bivšoj Jugoslaviji, utemeljiti i posebne ad hoc pomoćne organe, sa sudbenom funkcijom (Međunarodni krivični sud za bivšu Jugoslaviju, osnovan 1993. godine). Pod pojmom „razdruživanja” (3. tačka) mislilo se na početak postupka razdruživanja samostalnih država od ostalih federalnih jedinica i federacije i na gašenje tela, organa i institucija federacije, odnosno redefinisanje njihove uloge koja bi se mogla ostvariti u okviru novoformiranih institucija Saveza jugoslovenskih država. I u ovom postupku bi se koristili elementi međunarodne arbitraže. Tačka je predvidela da tokom postupka razdruživanja, a radi mirnog prenosa ovlašćenja, nastavljaju da funkcionišu pojedina tela, organi i institucije iz nadležnosti jugoslavenske federacije.

Četvrta tačka Plana odnosila se na zaključivanje ugovora o stvaranju saveza suverenih država, prema modelu Evropske zajednice, a taj bi postupak tekao istovremeno s postupkom razdruživanja, pa bi se na taj način nastavio svojevrsni kontinuitet funkcionisanja saveznih tela, u kontekstu njihovog preuređenja u Konfederaciji. Dati su temeljni ciljevi i zadaci budućeg udruživanja, koji nisu bitnije odstupali od Deganovog modela iz okto- 
bra 1990. godine; to su zajednički interesi u ekonomiji, području spoljnih poslova, obrane i poštivanja ljudskih i manjinskih prava. Striktno poštivanje ljudskih prava i prava nacionalnih manjina pod internim i međunarodnim nadzorom peti je osnovni postulat Rudolfovog predloga. Naglašavalo se kako će se vršiti nadzor nad izvršavanjem tih prava preko internih, a ako za to bude bilo potrebe i preko međunarodnih organa.

Odjeke Rudolfovog Plana u pet tačaka treba posmatrati u kontekstu tadašnjih okolnosti i zaključaka Brionske deklaracije, ${ }^{145}$ koja je od jugoslovenskih republika zahtevala nastavak pregovora za rešavanje krize. Jugoslovenska javnost mu je pristupala sa svojih već dobro profilisanih pozicija, iako ga je većina rukovodećih republičkih struktura ocenjivala kao dobru podlogu za nastavak pregovora. Stanovišta međunarodnih subjekata još uvek nisu bila dovoljno profilisana, što će uslediti od septembra 1991. godine kroz naglašeniju internacionalizaciju jugoslovenske krize. Očekivali su se i učinci brionskog dogovora.

Krajem avgusta 1991. godine, na predlog nemačkog ministra spoljnih poslova Hansa Ditriha Genšera, ${ }^{146}$ Savet ministara EZ donelo je odluku o sazivanju Konferencije o Jugoslaviji, radi rešavanja narastajuće krize. Za predsedavajućeg konferencije, koja je otpočela sa radom 7. septembra 1991. godine (završena je 12. decembra iste godine) imenovan je nekadašnji ministar spoljnih poslova u vladi Ujedinjenog Kraljevstva, lord Piter Karington. Istovremeno, Savet ministara Evropske zajednice je, 27. avgusta 1991. godine, u okviru Mirovne konferencije o Jugoslaviji, formirao i Arbitražnu komisiju, poznatu pod imenom Baditerova komisija, koja je imala zadatak da Konferenciju obezbeđuje pravnim savetima. Komisiju je, pored predsedavajućeg (Roberta Badintera, francuskog pravnika), činilo još pet članova - predsednika ustavnih sudova iz država članica EZ. Treba naglasiti da velike sile, posebno EZ i SAD, izuzev Nemačke i vatikanske diplomatije, u početku nisu bile sklone disoluciji (raspadu) Jugoslavije, već su se zalagale za određeni oblik njenog očuvanja. Po njima je institucionalna i državnopravna reforma Jugoslavije bila najbolje rešenje.

145 Brionska deklaracija je dokument koji su potpisali predstavnici Republike Slovenije, Republike Hrvatske i Socijalističke Federativne Republike Jugoslavije (SFRJ) posle proglašenja odvajanja Slovenije i Hrvatske od SFRJ i kratkotrajnih oružanih sukoba Teritorijalne odbrane (TO) Slovenije i JNA. Mirovni sporazum je potpisan pod političkim pokroviteljstvom Evropske zajednice, tj. trojice ministara iz država Evropske zajednice, na Brionima 7. jula 1991. godine. Trebalo je da obezbedi okruženje u kojem bi mogli da se održe dalji pregovori o budućnosti Jugoslavije. Brionskom deklaracijom predviđeno je da policija Slovenije kontroliše granicu, prema zakonima SFRJ, a da se JNA povuče u kasarne i zaustave sukobi, kao i tromesečno „zamrzavanje" odluka Slovenije i Hrvatske o izdvajanju iz SFRJ. Istovremeno je dogovoreno da se hitno izabere predstavnik Republike Hrvatske (Stipe Mesić) na mesto predsednika Predsedništva SFRJ. Sporazumom su prekinuta neprijateljstva između JNA i Teritorijalne odbrane Slovenije koja su trajala deset dana. Slovenija i Hrvatska su se složile da suspenduju delatnosti koje proizilaze iz njihovih deklaracija o nezavisnosti od 25. juna na tri meseca. Dokume-ntom je rešeno pitanje granične i carinske kontrole slovenačke granice, kontrola nad vazdušnim saobraćajem i odobrena razmena zarobljenika. Brionska deklaracija bila je i osnova za posmatračku misiju koja će pratiti sprovođenje sporazuma u Sloveniji. Jedanaest dana nakon potpisivanja deklaracije, Savezno izvršno veće je povuklo JNA iz Slovenije. Deklaracija nije imala uticaj na dalje odvijanje sukoba u Hrvatskoj.

${ }^{146}$ Nemačka diplomatija imala je posebno važno i istaknuto mesto u procesima internacionalizacije jugoslavenske krize. Za razliku od ostalih velikih sila koje su se zalagale za očuvanje jugoslovenskog državnog zajedništva, nemački kancelar Helmut Kol bio je izričit u svojim zahtevima za priznavanjem državne samostalnosti oni$\mathrm{h}$ jugoslavenskih republika koje to žele i koje ispunjavaju određene uslove. lako je u prvim istupima ovakva diplomatska inicijativa bila kritikovana, s obzirom na istorijska iskustva koja su ukazivala na nemačku želju za širenjem prema srednjoj i istočnoj Evropi, nemačko zalaganje će imati izuzetni značaj za proces afirmacije međunarodno priznanje Republike Hrvatske. 
Iz ugla međunarodnog prava osnovne protivrečnosti među velikim silama ogledale su se u njihovoj polarizaciji oko dva suprotstavljena načela: s jedne strane, insistiralo se na prihvatanju principa prava naroda na samoopredeljenje, koje je u međunarodnom pravu imalo svoju, iako ograničenu primenu, dok se na drugoj strani američka diplomatija pozivala na st. 4. čl. 2. Povelje UN, koja je zabranjivala bilo kakvu upotrebu sile „uperene protiv teritorijalne celovitosti ili političke nezavisnosti bilo koje države". S obzirom na to da je Hrvatska tada još, prema američkim gledištima, bila sastavni deo SFRJ, njena politika nije bila u skladu s temeljima prava Ujedinjenih naroda.

U vreme održavanja konferencije, 7. oktobra 1991. godine, vazduhoplovstvo JNA raketiralo je Banske dvore u Zagrebu, u trenutku kada je hrvatsko rukovodstvo vodilo razgovor sa saveznim premijerom (Antom Markovićem), a 8. oktobra je istekao tromesečni moratorijum na brionske odluke, posle čega će Hrvatski sabor proglasiti raskid svih državnopravnih veza sa jugoslovenskom federacijom i republikama koje su je činile i zatražiti međunarodno priznanje Hrvatske. U takvim okolnostima izmenila se i uloga Mirovne konferencije o Jugoslaviji koja je već u svojim zaključcima od 4. oktobra 1991. iskazala nameru da će međunarodno priznati sve države jugoslovenske federacije kao punopravne subjekte međunarodnog prava i poštovati njihove želje za stvaranjem nekog međunarodnog saveza.

Prva etapa u radu Konferencije, od 7. septembra do 4. novembra 1991. godine, bila je obeležena konkretnim pokušajima za rešavanje krize, u smislu stvaranja jednog saveza (konfederacije) jugoslovenskih država. U tom smislu, Konferencija je 4. novembra izradila i Nacrt Konvencije o miru u Jugoslaviji, koju su činili sledeći elementi:

1) Međunarodni ugovor. Konfederativni oblik državnog zajedništva temelji se na međunarodnom ugovoru kojim su definisani odnosi država u savezu. Savezu pristupaju samostalne i suverene države, s pravom njegovog odlaganja, a Konvencija predviđa mogućnost napuštanja konfederacije od strane jedne države koja stekne punopravno članstvo u Evropskoj zajednici. Osnovni uslov obrazovanja ovakvoga saveza je međusobno međunarodno priznanje svih država njegovih članica.

2) Vinculum juris (Pravna veza, uzori). Savremena nauka o međunarodnom pravu nema utemeljenja u istorijskom iskustvu koje poznaje formatirani primer sadržaja pravnog odnosa u okviru konfederacije. Uzori u stvaranju ove (jugoslovenske) konfederacije bili su sadržani u tadašnjim ugovorima Evropske zajednice, Mastrihtskom modelu Evropske unije koji je u to vreme nastajao i u pravu UN, prema dominantnim izvorima univerzalnog i specifičnog međunarodnog prava u oblasti zaštite ljudskih prava. Insistiranjem na takvim standardima, Konferencija o Jugoslaviji je pokušala da odgovori na teška kršenja ljudskih prava u Hrvatskoj u to vreme, zajamči manjinska prava srpskoj i drugim manjinama u Hrvatskoj i spreči buduće sukobe koji bi bili inspirisani nacionalnim motivima. Izbijanjem rata u Bosni i Hercegovini, kojim je jugoslovenska kriza dobila nove dimenzije, ovakva nastojanja će se ubrzo pokazati opravdanim. Prema uzoru na evropsku ekonomsku saradnju, u okviru EZ, jugoslovenske države trebalo je da sarađuju i na drugim područjima. Tako je konvencija predviđala pojedine oblike carinske unije, mogućnost uspostavljanja zajedničke tržišne i monetarne unije, tešnju saradnju u oblasti nacionalne sigurnosti, borbe protiv organizovanog kriminala, zajedničke policijske saradnje, u oblasti kulture, socijalne politike i dr.

3) Institucije. lako institucije nisu neminovno obeležja konfederacije, ukoliko postoje, one imaju pravnu prirodu konferencijskih organa, gde svaka država učestvuje sa jednim glasom ili jednakim brojem glasova i gde se odluke donose konsenzusom. Izvršna funk- 
cija ne postoji, a moguća su bila pojedina stručna, tehnička ili organizaciona tela koja bi olakšala funkcionisanje konfederacije. Konvencija o Jugoslaviji predvidela je institucije i u jugoslovenskoj konfederaciji (Veće, kao vrhovni organ za opštu saradnju i utvrđivanje osnovne politike konfederacije; Veće za ekonomsku saradnju; Veće za političku i bezbednosnu saradnju). Posebnu ulogu imao je i Sud za ljudska prava, a zaštitom ljudskih prava trebalo je da se bave i ad hoc komisije za ljudska prava (npr. sudovi za mirno rešavanje sporova) i drugi mehanizmi međunarodnog prava.

Kada se lord Karington prihvatio uloge predsedavajućeg Konferencije o Jugoslaviji, predsednik Saveta ministara spoljnih poslova EZ Hans van den Bruk mu je poručio da pokuša „u roku od dva meseca da postigne sveobuhvatno rešenje” za Jugoslaviju. Vrlo brzo će se pokazati da je uverenje kako se problemi raspada Jugoslavije mogu rešiti za tako kratko vreme bilo potpuno besmisleno i, kako je Karington kasnije izjavio, „znak da smo svi bili prilično nesvesni koliko će to biti teško ostvariti". Već posle prvog sastanka sa Tuđmanom i Miloševićem, 7. septembra 1991. (kada je održana prva sednica Konferencije), Karington je imao utisak da su dva najveća naroda spremna silom da nametnu rešenje ostatku Jugoslavije: „Kada sam prvi put razgovarao sa predsednicima Tuđmanom i Miloševićem, postalo mi je sasvim jasno da njih dvojica imaju uzajamno prihvatljivo rešenje, odnosno, da izvrše podelu. Nameravali su da podele Bosnu i Hercegovinu. Srpska (područja) bi išla Srbiji, hrvatska Hrvatskoj. I nisu mnogo brinuli, ni jedan od njih, šta će biti sa muslimanima. A što se Slovenije tiče, nije im bilo mnogo stalo do nje".

Slovenija je već de facto imala nezavisnost; ni Srbi ni Hrvati nisu brinuli o posledicama tog čina. Za Karingtona je pokušaj ponovnog „sastavljanja” Jugoslavije bio „isto što i zatvoriti vrata od štale, kad je konj već otkasao". U tom smislu, krenuo je od elementarne pretpostavke - da se Jugoslavija već raspala. Međutim, shvatio je, takođe, i posledice eventualnog priznavanja slovenačke i hrvatske nezavisnosti. Insistirao je da im se ona ne prizna dok se ne pronađe ustavno rešenje na nivou Jugoslavije, koje bi bilo prihvatljivo za sve republike.

Polazna tačka od koje je krenuo lord Karington u svom planu bilo je priznanje šest republika kao konstitutivnih jedinica bivše savezne države i ponudio plan koji bi svakoj od njih dao onoliko suvereniteta koliko su same želele. Bio je to, kako je i sam naglasio, pokušaj da se sastavi „meni” međurepubličkih institucija - za spoljnu politiku, ekonomska pitanja, zajedničku valutu, odbranu itd. Svaka republika bi odabrala institucije u kojima bi učestvovala: „Smatrao sam da je to ispravan način, jer bi omogućio onima koji žele nezavisnost da budu nezavisni i da se pridruže centralnoj organizaciji u onoj meri u kojoj to žele. Oni koji ne žele nezavisnost, e pa, oni bi mogli da ostanu u onome što je bila Jugoslavija. Drugim rečima, mogli bi to da urade, da tako kažem, á la carte". ${ }^{147}$

Karington se 4. oktobra dogovorio sa Tuđmanom, Miloševićem i Veljkom Kadijevićem da podele rad konferencije na dve radne grupe: prva, i važnija, trebalo je da se bavi ustavnim uređenjem buduće zajedničke države, a druga bi se posvetila zaustavljanju borbi u Hrvatskoj koje su od 7. septembra, kada je konferencija otpočela sa radom, drastično eskalirale. Na tom sastanku svi učesnici su se saglasili oko tri principijelne tačke od kojih je mirovna konferencija trebalo da krene. Prema zapisniku sa sednice, to su bile: 1) Labava asocijacija ili savez suverenih ili nezavisnih republika; 2) Odgovarajući spora-

\footnotetext{
147 "Jugoslavija á la carte", Plan lorda Karingrona, www.camo.ch/sj jugoslavija.htm
} 
zumi koji bi se sklopili radi zaštite nacionalnih zajednica, uključujući garantovanje ljudskih prava i eventualno davanje specijalnog statusa određenim područjima; 3) Nemogućnost jednostranih promena granica.

Izgledalo je da je Milošević, pod međunarodnim pritiskom, konačno prihvatio stav da republike, a ne narodi, predstavljaju legitimne konstitutivne jedinice savezne Jugoslavije. Četiri dana kasnije počela su zasedanja radnih grupa. Zadatak radne grupe za institucionalne odnose bio je da utvrdi oblasti od zajedničkog interesa, oko kojih bi se mogle izgraditi sve jugoslovenske institucije. Rasprava se gotovo odmah vratila na besplodno prepucavanje koje je bilo svojstveno predsedničkim sastancima na vrhu u proleće i leto 1991. godine. Stav Slovenije je bio da prihvati veoma ograničeni zajednički institucionalni okvir; Hrvatska je bila spremna na saradnju u brojnim oblastima, ali samo na međuvladinoj osnovi, pod uslovom da takva saradnja ne naruši njenu nezavisnost. Oba stava, sama po sebi, nisu bila u suprotnosti sa á la carte projektom lorda Karingtona, ali srpski stav jeste bio protiv. U zapisniku je o tome zabeleženo: „Srbija nije mogla da prihvati dalji tok razmatranja u radnim grupama koje bi se zasnivalo na najnižem mogućem imenitelju utvrđenih interesa i institucionalnih okvira. Konferencija treba da pokuša da utvrdi stvarne zajedničke interese koji bi se mogli braniti u zajedničkoj državi. Od suštinske je važnosti da svi Srbi žive u jednoj državi, a ne u više nezavisnih republika, povezanih nečim neznatno višim od međudržavnih odnosa. Ukoliko to ne prihvate ostale republike, ispravno bi bilo priznati one republike koje je žele (nezavisnost), ali tek pošto se reši pitanje sukcesije Jugoslavije i pošto se postigne dogovor o promeni granica". Drugim rečima, Srbiji se pripisivalo da želi da anektira one delove Hrvatske i Bosne i Hercegovine u kojima su Srbi bili većinsko stanovništvo, kao i da bude jedina legitimna država naslednica nekadašnje savezne države. Pristajanje na dobrovoljni raspad, poništilo bi ovakve ambicije.

Do sredine oktobra 1991. godine rat u Hrvatskoj se rasplamsao, a Karington je trpeo sve veće kritike zbog svoje upornosti da pronađe zajednički jezik sa onima koji su naložili razaranje Vukovara i opsadu i bombardovanje Dubrovnika. Republičkim liderima je 16. oktobra dostavio detaljan predlog na sedam strana, pod naslovom „Okvir za sveobuhvatno rešenje”. Međutim, sa razbuktavanjem rata u Bosni (početkom 1992) i intervencijom Ujedinjenih nacija, Karingtonov je plan definitivno gurnut u zapećak. Sam po sebi, on zaslužuje ipak daleko veću pažnju u odnosu na ono što je nastojao da postigne, budući da predstavlja dokaz do koje je granice međunarodna zajednica bila spremna da ide da bi umirila srpska strahovanja i zadovoljila njihove težnje. Plan je garantovao široku lepezu individualnih, kulturnih i političkih prava Srbima izvan Srbije. U onim područjima Hrvatske i Bosne u kojima su činili većinu, Srbi bi po ovom planu imali pravo da, po sopstvenom izboru, koriste nacionalna obeležja i zastave, pravo na drugo državljanstvo koje bi dobili pored državljanstva matične republike, kao i na sistem obrazovanja koji „poštuje vrednosti i potrebe" Srba. Konačno, dato im je pravo na sopstveni parlament, administrativnu strukturu, uključujući regionalne policijske snage i sopstveno sudstvo. ${ }^{148}$

Kada je u pitanju ishod Konferencije o Jugoslaviji, velika uloga se pripisuje Badinterovoj komisiji koja je, za dva meseca koliko se sastajala daleko od očiju javnosti, zaključila da se SFRJ raspala i da više ne postoji kao država. Već 7 . decembra 1991. na pitanje predsedavajućeg Mirovne konferencije lorda Karingtona postoji li uopšte Jugoslavija, arbitražna komisija je obja-

${ }^{148}$ Isto. 
Iskustva i pouke iz prošlosti

vila da se ta država raspala. Zbog toga je francuski pravnik, naučnik i političar Robert Badinter u srpskim medijima prozvan „grobarom Jugoslavije”. Zaključci Badinterove komisije, uobličeni u formi 10 mišljenja (formulisani od 29. novembra 1991. do 4. jula 1992. godine), devedesetih godina postali su deo međunarodnog javnog prava. Tako je u svom mišljenju, br. 1 od 29. novembra 1991, Arbitražna komisija saopštila da smatra da je Socijalistička Federativna Republika Jugoslavija stupila i proces raspadanja, da bi u mišljenju br. 8 (od 4. jula 1992) zaključila da je okončan proces raspadanja SFRJ i da ona više ne postoji, kao da ni jedan entitet koji je proistekao iz tog raspadanja ne može da pretenduje da bude isključivi naslednik SFRJ. ${ }^{149}$

Zaključci Badinterove komisije postali su jedan od temeljnih uslova za međunarodno priznanje Hrvatske, ali i za sve buduće pregovore o granicama između novih država. Bila je to prva velika diplomatska pobeda Hrvatske i nagoveštaj njenog priznanja. Ministarsko veće Evropske zajednice najavilo je priznanje Hrvatske za mesec dana, uz uslov da se zagarantuju prava srpskoj manjini. Hrvatski sabor je ubrzo doneo Ustavni zakon o ljudskim pravima i slobodama etničkih i nacionalnih zajednica i manjina. Badinterova komisija je taj zakon ocenila pozitivnim, pa je 15. jula 1992. godine Evropska zajednica priznala Republiku Hrvatsku, a zatim su priznanja stigla i od drugih država sa svih kontinenata.

U formalnom smislu, raspad Jugoslavije započeo je 25. juna 1991, kada su Slovenija i Hrvatska jednostrano proglasile nezavisnost, a okončao se 27. aprila 1992. godine proglašenjem Ustava Savezne Republike Jugoslavije (SRJ), države koju su obrazovale preostale članice bivše Jugoslavije (Srbija i Crna Gora). ${ }^{150} \mathrm{U}$ međuvremenu, Sloveniji i Hrvatskoj su se sličnim aktima pridružile Makedonija (Deklaracijom o nezavisnosti iz januara 1991) i Bosna i Hercegovina (Ustavnim amandmanima iz jula 1990, a zatim i Memorandumom i Platformom o položaju BiH iz oktobra 1991. godine). Države Evropske zajednice i Sjedinjene Američke Države priznale su 1992. godine suverenitet otcepljenim državama i, dok je tekao proces njihovog međunarodnog priznavanja u svetu, novorođene države bivaju primljene u Ujedinjene nacije. Jugoslavija se time formalno-pravno ugasila, a na njenim ruševinama krvavi građanski rat nastavio je da ubira plodove nagomilane mržnje koja je decenijama akumulirana među njenim narodima.

\section{Zaključna razmatranja: balkanske integracije danas}

Ideja balkanske federacije i praksa južnoslovenske (jugoslovenske) federacije obeležila je vek i po i ostavila dubok trag u istoriji balkanskih naroda (od sredine 19. pa gotovo sve do kraja 20. veka). Ponikla je u krugovima levičarske provenijencije; njeni nosioci po-

\footnotetext{
${ }^{149}$ Vidi: Rezolucije Saveta bezbednosti UN o krizi u bivšoj Jugoslaviji (i drugi dokumenti), Međunarodna politika, Pravni fakultet i Fakultet političkih nauka, Beograd, 1994.

${ }^{150}$ Neki autori smatraju da je proces raspada Jugoslavije zapravo započeo mnogo ranije - uvođenjem Ustava iz 1974. godine, koji je stvorio pretpostavke za otcepljenje republika od jugoslovenske federacije i stvorio de facto konfederaciju. Drugi, pak, smatraju da početak raspada Jugoslavije seže u 1989. godinu, kada je promena Ustava Srbije, odnosno, oduzimanje autonomije pokrajinama, dovela do ustavne krize na federalnom nivou.

S obzirom na to da je raspad Jugoslavije koincidirao sa izbijanjem građanskog rata, odnosno ratova u Hrvatskoj i Bosni i Hercegoviji, koji su se okončali tek sa Dejtonskim mirovnim sporazumom, deo autora smatra kako se raspad SFRJ završio tek 1995. godine, dok je po nekima on nastavljen sve do raspada Državne zajednice Srbija i Crna Gora 2006, te kroz jednostrano otcepljenje Kosova 2008. godine.
} 
tekli su iz redova socijalističkog, socijaldemokratskog i komunističkog opredeljenja, a živela je sa njima i u njima sve dok su oni predstavljali važan politički i ideološki činilac u istoriji svojih naroda i država.

Od 1948. godine ideja o balkanskoj federaciji u svom izvornom obliku ne figurira više kao integrativni činilac među balkanskim narodima, a devedesetih godina prošlog veka i federacija kao oblik jugoslovenskog državnog zajedništva prestala je da postoji. Sa geopolitičkom prekompozicijom Evrope, koja je otpočela padom Berlinskog zida 1989. godine, i tranzicijom bivših socijalističkih država, otpočela je i njihova integracija u Evropsku uniju; među njima su i pojedine balkanske države (Bugarska) koje su u prethodnim periodima bile glavni promoteri balkanske federacije. Na Balkanu je ovaj proces počeo raspadom SFRJ i stvaranjem novih država na njenim ruševinama. Neke od bivših jugoslovenskih republika (Slovenija i Hrvatska) postale su članice Evropske unije, a ostale (zemlje Zapadnog Balkana - Srbija, Crna Gora, Bosna i Hercegovina i Makedonija) zvanično su istakle svoju kandidaturu za priključenje evropskoj zajednici naroda. U međuvremenu, ideja zajedništva među državama Balkana, pre svega bivšim jugoslovenskim republikama na ekonomskoj osnovi, nastoji da preživi kroz neke nove inicijative i oblike (asocijacije), mimo Evropske unije, ali uz njenu pomoć i podršku.

Razdoblje između 1995. i 2015. godine iznedrilo je mnoge multilateralne inicijative koje su nudile potencijalno rešenje za zemlje nastale raspadom SFRJ. ${ }^{151}$ Još je 1992. godine tadašnji premijer SR Jugoslavije Milan Panić projektovao eufemističnu alternativu bivšoj Jugoslaviji. On se tada založio za privremenu kantonizaciju Bosne i Hercegovine, koja je po njemu bila najbolji način da se zaustavi rat u ovoj republici. Predlagao je i redizajn SFRJ, koja bi se transformisala u Balkansku Federaciju (United States of Balkans) ili u Ekonomsku uniju Balkana, u koju bi ušle sve bivše socijalističke balkanske države. ${ }^{152}$

Uoči i tokom rata u Bosni i Hercegovini nuđena su četiri mirovna plana koja su izradili diplomati Evropske zajednice i Ujedinjenih nacija, kako bi se rat u ovoj republici predupredio ili zaustavio: 1. Karington-Kurtiljerov plan iz februara 1992, poznat još kao Lisabonski sporazum; 2. Vens-Ovenov plan iz januara 1993; 3. Oven-Stoltenbergov plan iz jula 1993. i 4. Plan Kontakt grupe iz 1994. godine. ${ }^{153}$ U međuvremenu, u martu 1994. godine okončani

${ }^{151}$ O tome više: Saša Knežević, Nikola Zečević „Multiratelarne inicijative na Balkanu u razdoblju između 1995. i 2015. godine", Međunarodne studije, časopis za međunarodne odnose, vanjsku politiku i diplomaciju Centra za međunarodne studije u Zagrebu, Hrvatske udruge za međunarodne studije i Visoke škole međunarodnih odnosa i diplomacije Dag Hamaršeld (Dag Hammarskjöld), vol. 15, br. 2/1015, str. 31-43.

${ }^{152}$ Kulturna skupnost Slovenije, Nova revija, Cankarjeva založba, sv. 16, 1997, str. 200.

${ }^{153}$ Karington-Kurtiljerov plan je predlagao etničku konsolidaciju na svim administrativnim nivoima i davanje većih ovlašćenja lokalnim vlastima na štetu centralne vlasti. Međutim, svi okruzi bili su klasifikovani kao muslimanski, srpski i hrvatski, pa i kad nije postojala određena etnička većina. Narodna skupština Srpske Republike Bosne i Hercegovine je 11. marta 1992. jednoglasno odbacila plan, predlažući novi po kojem bi Srbi imali kontrolu na oko dve trećine Bosne i Hercegovine, stvarajući time muslimanske i hrvatske enklave bez teritorijalnog jedinstva. Ovaj plan odbio je Kurtiljero, ali je izneo predlog po kojem bi tri nacionalne jedinice bile „zasnovane na nacionalnim principima, uzimajući u obzir ekonomske, geografske i druge kriterijume" (Josip Glaurdić, The Hour of Europe: Western Powers and the Breakup of Yugoslavia. London: Yale University Press. 2011, str. 294).

Početkom januara 1993. godine specijalni izaslanik Generalnog sekretara UN Sajrus Vens i predstavnik Evropske zajednice Dejvid Oven započeli su pregovore o miru sa zaraćenim stranama u Bosni i Hercegovini. Predlog, koji će postati poznat kao „Vens-Ovenov mirovni plan”, delio je BiH na deset poluautonomnih oblasti, a podržale su ga UN. lako je predsednik Republike Srpske Radovan Karadžić prihvatio sporazum, 30. aprila 1993, Narodna skupština ga je odbila 6. maja i naknadno odluku prenela na referendum 
su sukobi između Hrvata i Muslimana u Bosni i Hercegovini, kada su dve sukobljene strane potpisale Vašingtonski sporazum. ${ }^{154}$ Sukob u Bosni i Hercegovini rešen je tek 1995. godine Dejtonskim mirovnim sporazumom, kojim je prekinut rat, a Bosna i Hercegovina je podeljena na dva dela: Federaciju Bosne i Hercegovine i Republiku Srpsku.

$\mathrm{U}$ isto vreme, bilo je i domaćih - muslimanskih, srpskih i hrvatskih predloga za reorganizaciju Bosne i Hercegovine. Još u vreme dok je postojala Jugoslavija, Srbi su na prostoru Hrvatske i Bosne i Hercegovine formirali autonomne oblasti, sa tendencijom da one postanu nezavisne. Od srpskih autonomnih oblasti u Hrvatskoj nastaće Republika Srpska Krajina, a od oblasti u Bosni i Hercegovini Republika srpskog naroda Bosne i Hercegovine. Kako su etničke tenzije rasle, jedan od prvih muslimanskih predloga bilo je osnivanje tri entiteta unutar Bosne i Hercegovina, a plan je saopšten 25. juna 1991. godine. Predlagao je stvaranje muslimanskog, srpskog i hrvatskog entiteta. Drugi plan potekao je od muslimanske Stranke demokratske akcije i Hrvatske demokratske zajednice $\mathrm{BiH}$, u avgustu 1992. godine. Njime je bilo zamišljeno uspostavljanje dvanaest kantona, bez prava na autonomiju.

Sporazum Karadžić-Filipović, poznat i kao Srpsko-muslimanski „istorijski sporazum”, postignut je između muslimanskih predstavnika koje je predvodio Muhamed Filipović i srpskih predstavnika na čelu sa Radovanom Karadžićem. Pregovori su vođeni tokom leta 1991. godine, a sporazum je potpisan u julu iste godine. Prvi put je bio objavljen u Beogradu 2. avgusta 1991 . $^{155}$ Pregovore je pokrenula muslimanska strana koju su predstavljali Muhamed Filipović i Adil Zulfikarpašić, uz odobrenje Alije Izetbegovića, a povod je bio raspad Jugoslavije od koje su se već otcepile Slovenija, Hrvatska i Make-

(Bosnian Serbs Spurn Un Pact, Set Referendum, Chicago Trubune, 6. May 1993). Glasači su na referendumu 16. maja većinom od $96 \%$ odlučili da ne prihvate plan (Republika Srpska (Bosnien-Herzegowina), 16. Mai 1993: Vance-Owen-Friedensplan Direct Democracy), označavajući ga kao „varku”. Dejvid Oven je 18. juna plan proglasio „mrtvim”. Imajući u vidu tempo kojim su se razvijali događaji u BiH, plan je zastario i pre njegovog objavljivanja. To je bio poslednji predlog koji je trebalo da sačuva jedinstvenu Bosnu i Hercegovinu; ostali predlozi nudili su njenu podelu.

Krajem jula 1993. godine predstavnici zaraćenih strana u ovoj republici ušli su u novu fazu pregovora. Specijalni izaslanik generalnog sekretara UN Tornvald Stoltenberg i predstavnik Evropske zajednice Dejvid Oven predstavili su novu kartu podele $\mathrm{BiH}$ na tri etničke minidržave, po kojoj bi Srbi imali kontrolu nad $52 \%$ teritorije $\mathrm{BiH}$, Muslimani oko 30\%, a Hrvati preostalih 18\%. Muslimani su 29. avgusta odbili ovaj plan.

Između februara i oktobra 1994. godine Kontakt grupa je ostvarila određeni napredak u sporazumnom rešavanju rata u BiH. Plan Kontakt grupe je predviđao državno uređenje po kojem bi Srbima pripalo $49 \%$ teritorije, što je bilo za trećinu manje od onoga što su kontrolisali (Bosnian Serbs, in Referendum, Reject Peace Plan New York Times, 30 August 1994). Nad njima je vršen jak pritisak kako bi prihvatili plan, a jedan od načina pritiska bio je i embargo na Drini. Plan je odbijen na referendumu 28. avgusta 1994. godine sa većinom od 96,66\% (Republika Srpska (Bosnien-Herzegowina), 28. August 1994: Teilungsplan der internationalen Kontaktgruppe Direct Democracy).

${ }^{154}$ Vašingtonski sporazum ticao se prekida vatre između zaraćenih strana Republike Hrvatske, Herceg-Bosne i Republike Bosne i Hercegovine. Potpisan je u Vašingtonu 18. marta 1994, a ratifikovan kasnije u Beču (Bethlehem, Daniel L.; Weller, Marc (1997). The 'Yugoslav' Crisis in International Law. Cambridge International Documents Series. 5. Cambridge University Press. str. liiv. ISBN 978-0-521-46304-1). Sporazum su potpisali premijer promuslimanske vlade Bosne i Hercegovine Haris Silajdžić, hrvatski ministar inostranih poslova Mate Granić i predsednik Herceg-Bosne Krešimir Zubak. Prema sporazumu, teritorija koja se nalazila pod kontrolom hrvatskih i muslimanskih snaga podeljena je na deset autonomnih kantona i uspostavljena je Federacija Bosne i Hercegovine. Kantonalni sistem je uspostavljen sa ciljem da spreči dominaciju jedne etničke grupe nad drugom.

155 „Srpsko-muslimanski `istorijski sporazum”. Oslobođenje, 2. 8. 1991. godine. 
donija. Njihova želja je bila da se urede odnosi Bosne i Hercegovine sa ostatkom Jugoslavije i osigura puna ravnopravnost muslimana sa ostalim narodima u zemlji u kojoj su želeli da ostanu, pored ostalog, i zbog velikog broj muslimana u Sandžaku. Insistirali su na teritorijalnoj celovitosti Bosne i Hercegovine, što je bio minimum muslimanskih zahteva u ovim pregovorima. ${ }^{156}$

Radovan Karadžić je prihvatio pregovore, a kao minimum srpskih zahteva istakao je želju Srba da ostanu u jednoj državi, bez obzira na njenu formu. Na srpskoj strani pregovarači su bili Nikola Koljević, Momčilo Krajišnik i Biljana Plavšić. Osnovna načela od kojih se pošlo u pregovorima bila su da Bosna i Hercegovina ostane u Jugoslaviji (čime bi se realizovao najvažniji cilj srpske politike) i zadrži puni suverenitet, kao i da ostane u svojim granicama sa statusom države koja sa ostalim članicama zajedničke države ima spoljnu politiku, vojsku, carine, novac i opštu ekonomsku politiku, dok bi u ostalim oblastima bila samostalna. ${ }^{157}$ Međutim, početak rata u Bosni i Hercegovini (1992) učinio je ovaj sporazum bespredmetnim.

U avgustu 1992. godine Slobodan Milošević se na Londonskoj konferenciji pojavio sa kontroverznom inicijativom o formiranju Balkanske konfederacije, u čiji sastav bi ušle Srbija, Crna Gora, Makedonija, Grčka i Rumunija. ${ }^{158}$ Miloševićeva inicijativa bila je odbačena na samoj Konferenciji, a službena SRJ u vreme njegove vladavine, kao i nakon njegovog političkog sloma, nije imala nikakav stav prema takvoj vrsti inicijative. Na pitanje hrvatskog novinara Vladimira Barišića (Večernji list) povodom potencijalnog formiranja balkanske unije, prvi ministar spoljnih poslova SRJ nakon „petooktobarskih” promena (2000. godine) Goran Svilanović je kategorički izjavio: „Nismo zainteresovani za Balkansku uniju”. ${ }^{59}$ Nasuprot tome, u januaru 2003. godine grčki šef diplomatije Jorgos Papandreu u izjavi za Süddeutsche Zeitung je poručio: „Oživljavamo viziju Balkanske Federacije!” Kako je kasnije objašnjeno, ova poruka imala je jasan diplomatski podtekst koji je podrazumevao samo poziv na intenzivniju multilateralnu saradnju u regionu. Ništa više od toga. ${ }^{160}$ Iste će godine, povodom ove konstatacije, uslediti i izjava švedskog diplomate Karla Bilda, koji je za hrvatski „Globus” komentarisao: „Ona je dobra za vas. (...) Možda vi i ne znate, ali Hrvatska je već u balkanskoj uniji, jer je zapadni Balkan njezina prirodna regija”. ${ }^{161}$ Gotovo istovremeno, Frankfurter Algemeine Zeitung preneo je tekst veoma sugestivnog naslova - „Balkanske zemlje samo povezane postaju zanimljiva tržišta", u kojem se u perspektivi insistira na postojanju Balkanske ekonomske unije (BEU), njezinog ustava, zajedničkog parlamenta i sl. ${ }^{162}$

\footnotetext{
${ }^{156}$ Muhamed Filipović, „Historijski sporazum”. Nezavisne novine.

${ }^{157}$ Isto.

${ }^{158}$ Sander Oral, The Balkan and Black Sea Cooperation, Ankara, Foreign Policy, sv. 17, 1993., str. 394; „Milošević se godinu dana ranije, u izjavi za grčku televizijsku mrežu „Antena”, založio za jugoslovensko-grčku konfederaciju: „Ja sam uveren da bi jedna jugoslovensko-grčka konfederacija bila, siguran sam, faktor stabilnosti u regionu i u interesu grčkog i srpskog naroda". Takvi se Miloševićevi stavovovi, međutim, mogu pripisati njegovoj želji da se na Zapadu predstavi kao političar koji teži regionalnoj saradnji, ali i da, u okviru jugoslovenske federacije, zadrži Makedoniju. Na isti način, može biti simptomatično nespominjanje Bugarske kao potencijalne članice Balkanske Konfederacije” (Saša Knežević, Nikola Zečević, „Multiratelarne inicijative na Balkanu u razdoblju između 1995. i 2015. godine”, Međunarodne studije, vol. 15, br. 2/1015, str. 32).

${ }^{159}$ Večernji list, 14. novembar 2001, str. 8.

${ }^{160}$ Slobodna Dalmacija, „Grčka ipak ne želi Balkan-federaciju”, 8. januar 2003, str. 2-3.

${ }^{161}$ Anđelko Milardović, Pod globalnim šeširom, Zagreb, Centar za politološka istraživanja, 2004, str. 120

${ }^{162}$ Isto, str. 121.
} 
Sa sličnim inicijativama pojavljivaće se i pojedini intelektualci i naučnici iz regiona, insistirajući na potrebi da ova ideja zaživi u javnosti. U jednom od svojih radova, raspravljajući o tehnološkom potencijalu balkanskih zemalja, turski profesor Nazmi Ozer piše: „Kulturne, socijalne, ekonomske, pa čak i klimatske sličnosti balkanskih zemalja trebaju se tretirati kao dobra šansa za obezbeđivanje novih tehnologija, uz uslov da se ujedine u 'Balkansku uniju', zato što bi jedino tada veličina populacije bila dovoljna za fizibilnost (izvodljivost - prim. autor) tehnološkog razvoja". Kao ključni faktor za proizvodnju novih tehnologija, Ozer navodi da nijedna balkanska država nema dovoljno veliku populaciju koja bi mogla podržati tehnološku proizvodnju, te da svaki vid napretka zavisi od obrazovne, ekonomske i političke integracije ovog prostora. ${ }^{163}$

Istovremeno, hrvatski profesor Branko Horvat zalagao se za formiranje Balkanske ekonomske unije, smatrajući da bi balkanske države u Evropskoj uniji bile svojevrsni prosjaci koji bi bili primorani da žive od donacija iz Brisela. U tom smislu, zanimljiva je analogija sa tumačenjima pojedinih verskih krugova u Hrvatskoj kada je, uoči referenduma o ulasku Hrvatske u EU, dr Goran Črpić (Hrvatska biskupska konferencija) izneo tezu kako alternativa Evropskoj uniji može biti samo Balkanska unija, sugerišući da se Hrvatska ulaskom u EU vraća civilizacijskom krugu kojem i pripada istorijski, te da bi sve drugo bilo korak unazad.

Srpski teoretičar Andrej Grubačić, direktor i osnivač Odseka za antropologiju i društvene promene u Kalifornijskom institutu za integralne studije u San Francisku, u svojoj knjizi „Don't Mourn, Balkanize! Essays After Yugoslavia” iz 2010. godine zalaže se i sam za ideju balkanske federacije, naglašavajući da je njegov antipod federaciji socijalističkih država zapravo socijalistička federacija - bez država: „Ja se zalažem za drugačiji Balkan, ne ni kapitalistički, ne ni birokratsko-socijalistički, već za transetničko društvo sa polikulturalističkim pogledom koji prepoznaje višestruke i preklapajuće identitete i veze zasnovane na dobrovoljnoj saradnji, uzajamnoj pomoći, direktnoj demokratiji grupisanih saveta i samoupravnoj privredi sa participativnim planiranjem, uramljenim u regionalni okvir federacije. (...) Balkanizacija Evrope bi se zasnivala na politici autonomnih regiona i pluralitetu kultura. Region vidim kao entitet, prethodno istrošen od strane centralizovane nacionalne države i kapitalizma, kao osnovu za obnovu i rekonstrukciju društvenog i političkog života Evrope. Moj Balkan je Balkan regionalnih jedinica, a ne nacija, koje opravljaju svoju kulturnu raznovrsnost, regionalni politkulturni identitet koji je izgubljen kroz njihovo uključivanje u okvir nacionalne države. Iz tih razloga ja ne zagovaram podršku za novu, monoetničku, nacionalnu državu Kosovo. Moto koji bih ja voleo da ponudim je mnogo drugačiji: 'Ne država, ne nacija, već Balkanska Federacija!' Projekat Balkanske federacije je projekat temeljne dekolonizacije, polikulturalnosti, društvene promene odozdo ka gore, analogno i u aktivnoj komunikaciji sa sličnim savremenim projektima. Regionalna iskustva Balkana, kao što je istorijsko iskustvo samoorganizacije, može balkanizovati i denacionalizovati evropske političke strikture..."164

Levičarski intelektualac i pisac Tarik Ali u intervjuu za grčki magazin „Hot Doc” 2012. godine se, takođe, založio za koncept balkanskih integracija: „... Kreiranje regionalnih saveza mora biti važno pitanje u narednim godinama. Zašto ne i Balkanske konfederacije koja bi ojačala svaku zemlju u zajedničkom glasu protiv birokratije Evropske unije?"165 Sociolog

\footnotetext{
${ }^{163}$ Nazmi Özer, Difficulties of Developing Countries in Obtaining New Technologies: Special Emphasis on Balkan Countries, Science and Technology Management, IOS Press, s.l., 1998, str. 23.

${ }^{164}$ Grubačić, Andrej, Don’t Mourn, Balkanize!: Essays After Yugoslavia, PM Press, 2010.

${ }^{165}$ Counter Punch; url: http://www.counterpunch.org/2012/11/15/tariq-ali-on-the-future-of-greece/
} 
Andreja Živković, sa Univerziteta u Kembridžu, insistira na revolucionarnoj tradiciji balkanskih naroda: „Ovaj sistem ne može opstati i moramo reći da neće biti bolje! (...) Balkanska federacija je ekonomski, socijalni i politički program oslobođenja Balkana. Ako se ujedinimo, pobedićemo". Prema njegovom shvatanju, ukoliko se prepustimo Evropskoj uniji, bićemo skrojeni kao „pacificirana kolonija i potrošačka pustinja”: „U njoj ćemo skupo plaćati uvezenu evropsku robu izvozom radne snage. Alternativa je balkanska federacija!"166

Nakon potpisivanja Dejtonskog sporazuma 1995. godine nastupilo je razdoblje konsolidacije multilateralne saradnje na Balkanu. U tom smislu, u Sofiji je 1996. godine pokrenut Proces saradnje u jugoistočnoj Evropi (PSuJIE/SEECP), kao okvir regionalne saradnje koji je funkcionisao na nivou redovnih godišnjih sastanaka ministara spoljnih poslova zemalja članica ove inicijative. Ona je od početka bila posvećena unapređenju međudržavne saradnje u oblasti bezbednosti, političkih i ekonomskih odnosa, pravosuđa, razvoja demokratije i drugim oblastima, radi sticanja uslova za približavanje zemalja regiona evropskim i evroatlantskim strukturama.

Članovi inicijative na početku su bili Albanija, Bugarska, Grčka, SR Jugoslavija, Makedonija, Rumunija i Turska. Vremenom joj se priključuju Hrvatska, Bosna i Hercegovina, Moldavija, Slovenija i Crna Gora (2007), a Srbija će, kao naslednik državne zajednice Srbija i Crna Gora (SR Jugoslavije) naslediti i njeno članstvo u ovoj organizaciji, koja danas ima 12 članica. Osim godišnjih sastanaka ministara spoljnih poslova, praktikovani su i samiti u okviru kojih su se sastajali šefovi država ili vlada. Najznačajniji dokument ove inicijative je Povelja o dobrosusedskim odnosima, stabilnosti, sigurnosti i saradnji u Jugoistočnoj Evropi, doneta 2000. godine na samitu u Skoplju, koja je afirmisala ideju o međudržavnoj saradnji i evroatlantskim integracijama regiona. Zanimljivo je da se, zbog nerešenog spora između Grčke i Makedonije u zvaničnim dokumentima ove organizacije nisu navodili nazivi zemalja, već samo lična imena učesnika, ili glavni gradovi, a u salama za sastanke države su bile predstavljene zastavama. ${ }^{167}$

U kontekstu ove inicijative važan je bio sastanak u Solunu, juna 1997. godine, na kojem je usvojena tzv. Solunska deklaracija ministara spoljnih poslova, u kojoj se naglašavala „evropska orijentacija država regiona, kao integralni deo njihovog političkog, ekonomskog i društvenog razvoja”. U okviru ove deklaracije bila je predviđena i politička, ekonomska, humanitarna, ekološka, socijalna i kulturna saradnja između balkanskih zemalja. ${ }^{168}$ Sastanak balkanskih šefova država ili vlada na Kritu 1997. godine predstavljaće značajan korak u pravcu razvoja multilateralne saradnje. Tada je, u okviru Kritske izjave, iskazano jedinstveno zalaganje za afirmaciju dobrosusedskih odnosa u ovom delu Evrope. Tom prilikom doći će i do istorijskog sastanka predsednika SR Jugoslavije i Albanije, Slobodana Miloševića i Fatosa Nanoa. Ovaj sastanak je opisan kao prvi jugoslovenskoalbanski susret na vrhu, nakon susreta Josipa Broza i Envera Hodže 1947. godine. ${ }^{169}$

Na samitu u Beogradu 2003. godine, kojem je prisustvovao i predsednik Evropske komisije Romano Prodi, inicirana je rasprava o viznoj liberalizaciji, kao i privrženost prin-

\footnotetext{
${ }^{166}$ Večernje novosti, „Alternativa je balkanska federacija”, br. 606, 2012. godine

${ }^{167}$ Duško Lopandić, Jasminka Kronja, Regionalne inicijative i multilateralna saradnja na Balkanu, Beograd, 2010, str. 58.

${ }^{168}$ The Southeast European Yearbook, 1997-1998, Atena, ELIAMEP, 1998., str. 485-495.

${ }^{169}$ Louis Sell, Slobodan Milosevic and the destruction of Yugoslavia, s.I., Duke University Press, 2002., str. 278.
} 
cipu očuvanja suvereniteta i teritorijalnog integriteta u sprovođenju Dejtonskog sporazuma, saradnji sa Haškim tribunalom i naglašena zajednička stremljenja u pravcu evroatlantskih integracija. ${ }^{170} \mathrm{U}$ Sarajevskoj deklaraciji iz 2004. godine oštro je osuđeno „etnički motivisano” nasilje na Kosovu u kojem su izgubljeni ljudski životi i uništeno versko i kulturno nasleđe, koje je „zajedničko vlasništvo svih Evropljana”. ${ }^{171}$ Data je podrška proširenju NATO-a i EU, te izraženo uverenje da će se uskoro Bosna i Hercegovina, ali i Srbija i Crna Gora, uključiti u Partnerstvo za mir. ${ }^{172} \mathrm{Na}$ osmom samitu u Bukureštu (2005) naglašena je važnost Kosova kao najznačajnijeg bezbednosnog pitanja u regionu i data puna podrška dijalogu između Beograda i Prištine, kao i poštovanju „Rezolucije 1244” UN-a.

Na samitu u Solunu 2006. godine Grčka je predložila Akcioni plan za institucionalno jačanje PSUJIE, kao osnovu za formiranje nove strukture regionalne saradnje koja će biti formalizovana naredne godine, na samitu u Zagrebu 2007. godine. Naime, Pakt o stabilnosti za Jugoistočnu Evropu ${ }^{173}$ tom prilikom biće transformisan u operativno telo - Veće za regionalnu saradnju - VRS (ili Savet za regionalnu saradnju - RCC). Tada je utvrđen i Statut nove organizacije, a za njeno sedište (Sekretarijat Saveta za regionalnu saradnju) bilo je određeno Sarajevo. Zadaci koji su se našli pred Većem za regionalnu saradnju bili su: jačanje stabilnosti i dijaloga u regionu, operativno povezivanje interesa regiona i interesa EU (kroz razvojne projekte u okviru IPA programa ${ }^{174}$ ), koordinacija međunarodne

${ }^{170}$ Ministarstvo vanjskih i europskih poslova Republike Hrvatske, url: http://www.mvpei.hr/ seecp/docs/5_BELGRADE_DECLARATION_9_APRIL_2003.pdf

${ }^{171}$ Reč je o otvorenom etničkom sukobu iz marta 2004. godine, kojom prilikom je spaljeno nekoliko stotina srpskih kuća i oštećeno ili uništeno 27 srpskih pravoslavnih manastira (Human Rights Watch, Not on the Agenda, The Continuing Failure to Address Accountability in Kosovo Post-March 2004, s.l., Human Rights Watch, svezak 18, 2006., str. 6).

${ }^{172}$ D. Lopandić, J. Kronja, Regionalne inicijative i multikateralna saradnja na Balkanu, str. 67.

${ }^{173} \mathrm{Na}$ inicijativu Evropske unije, 10. juna 1999. godine u Kelnu je usvojen osnivački dokument Pakta stabilnosti za jugoistočnu Evropu, kojim je više od 40 zemalja i međunarodnih organizacija preuzelo obavezu pružanja podrške zemljama regiona u njihovim naporima da unaprede mir, demokratiju, poštovanje ljudskih prava i ekonomski prosperitet. Političku potvrdu Pakt je dobio prilikom sastanka na vrhu u Sarajevu, 30. jula 1999. godine, a operativno je zaživeo održavanjem regionalnog stola 16. septembra 1999. godine. Pakt stabilnosti postavljao je okvir za saradnju zemalja regiona jugoistočne Evrope (Albanije, Bosne i Hercegovine, Bugarske, Mađarske, Makedonije, Moldavije, Rumunije, Slovenije, Turske, Hrvatske, te Srbije i Crne Gore - tadašnje SRJ), država članica EU, Sjedinjenih Američkih Država, Ruske Federacije i međunarodnih organizacija (Organizacija za bezbednost i saradnju u Evropi - OEBS, Savet Evrope - SE, Ujedinjene nacije - UN, Severnoatlantski savez - NATO, Zapadnoevropska unija - ZEU, Visoki komitet Ujedinjenih nacija za izbjeglice - UNHCR i Organizacija za ekonomsku saradnju i razvoj - OECD), uključujući i međunarodne finansijske institucije (Međunarodni monetarni Fond - MMF, Svetsku banku - SB, Evropsku investicionu banku - EIB i Evropsku banku za obnovu i razvoj - EBRD), te regionalne inicijative (Rojamon proces, Ekonomska saradnja crnomorskih zemalja - BSEK, Centralnoevropska inicijativa - CEI, Inicijativa za saradnju u jugoistočnoj Evropi - SEKI i Proces saradnje jugoistočne Evrope - SEECP). Strateški cilj Pakta bio je približavanje država jugoistočne Evrope evroatlantskim strukturama i jačanje regionalne saradnje. U organizacionom smislu, Pakt za stabilnost oslanjao se na specijalnog koordinatora kojeg je imenovala Evropska unija nakon konsultacija sa učesnicima Pakta, a potvrđivao ga je predsedavajući OEBS-a. Rad Pakta za stabilnost odvijao se preko političkog instrumenta Pakta - regionalnog stola, u okviru kojeg su funkcionisala tri radna stola: radni sto I - demokratizacija i ljudska prava; radni sto II - ekonomska rekonstrukcija, saradnja i razvoj; radni sto III - bezbednost i odbrana, pravosuđe i unutrašnji poslovi. Sedište Sekretarijata Pakta stabilnosti bilo je u Briselu. Pakt stabilinosti je 2008. godine prerastao u Savet za regionalnu saradnju (RCC).

174 Instrument za pretpristupnu pomoć (IPA) finansijski je instrument EU koji podržava strategiju proširenja EU, čiji je cilj pružanje pomoći kandidatima i potencijalnim kandidatima u procesu pridruživanja EU. Reč je o jedinstvenom pretpristupnom instrumentu EU za budžetsko razdoblje od 2007. do 2013. godine (IPA I) i za bu- 
političke, tehničke i finansijske podrške. Veće za regionalnu saradnju biće profilisano kao regionalni forum za dijalog.

Na samitu u Pomorju (Bugarska) 2008. godine doći će do prvih nesuglasica po pitanju statusa Kosova. Kada je predstavnik UMNIK-a tokom sastanka dao reč „ministru spoljnih poslova Kosova", delegacija Srbije je napustila ovaj skup. Pitanje Kosova se samo po sebi nametnulo kao ozbiljan problem, jer je 7 od ukupno 12 članica PSuJIE priznalo kosovsku nezavisnost (Albanija, Bugarska, Crna Gora, Hrvatska, Makedonija, Slovenija, Turska). Istovremeno, pozdravljeno je uvođenje vizne liberalizacije građanima Srbije, Crne Gore i Makedonije, uz očekivanje da će Evropska unija to učiniti i sa Albanijom i Bosnom i Hercegovinom.

Od 2011. godine Veće za regionalnu saradnju kreira trogodišnji dokument, pod nazivom Strategija i program rada, s težištem na Strategiji JIE 2020 (Strategija razvoja Jugoistočne Evrope) čiji je cilj postizanje visokog i održivog ekonomskog razvoja, a samim tim i podsticanje većeg privrednog rasta u regionu, većeg prosperiteta i otvaranje novih radnih mesta, a sve kroz jačanje regionalne saradnje i veze sa EU. Strategija je jasno usmerena na poboljšanje konkurentnosti Jugoistočne Evrope. Od 2013. godine na čelu Veća nalazi se srpski diplomata Goran Svilanović. Ovu inicijativu pokušaće da nadogradi nova - WB6 („zapadnobalkanska šestorka") koju je 2013. godine formulisao crnogorski ministar spoljnih poslova Igor Lukšić, u okviru koje je predloženo formiranje zajedničke parlamentarne skupštine u kojoj bi svaka država članica imala po deset delegata; zatim, stvaranje jedinstvene bespasoške zone; formiranje BALPOL-a kao regionalnog policijskog centra koji će omogućiti funkcionalnu saradnju u borbi protiv organizovanog kriminala i korupcije, te zajednički nastup na trećim tržištima. Inicijativu je podržao i tadašnji srpski premijer Ivica Dačić, predloživši formiranje Balkanskog veća po uzoru na Nordijsko veće, a o njenim potencijalnim prednostima indirektno će progovoriti i hrvatski biznismen Ivica Todorić, koji je tim povodom pozvao na "hitno stvaranje balkanskog Beneluksa”. U preostalom delu regionalne javnosti ideja o „zapadnobalkanskoj šestorci" nije rado dočekana, ali ju je podržao službeni Brisel. Radni naslov inicijative nešto kasnije je preimenovan u WB6+2, usled zanimanja Hrvatske i Slovenije da u njoj sudeluju. ${ }^{175}$

U kontekstu multilateralne saradnje na Balkanu, važno je pomenuti i tematsku inicijativu pod nazivom Central European Free Trade Agreement / Centralnoevropski ugovor o slobodnoj trgovini (CEFTA). Reč je o trgovinskom sporazumu između Albanije, Bosne i Hercegovine, Makedonije, Moldavije, Srbije, UNMIK-a (koji zastupa Kosovo i Metohiju) i Crne Gore. Osnovale su je Poljska, Čehoslovačka (kasnije Češka i Slovačka zasebno) i Mađarska (zemlje tzv. Višegradske grupacije) još 1992. godine u Krakovu, a u periodu od 1996. do 2004. godine inicijativi će se pridružiti i Slovenija, Rumunija, Bugarska i Hrvatska. Budući da članstvo u Evropskoj uniji (kao carinskoj uniji) nije bilo kompatibilno s članstvom u organizaciji CEFTA (kao zoni slobodne trgovine), tu će inicijativu 2004. godi-

\footnotetext{
džetsko razdoblje od 2014. do 2020. godine (IPA II). Prioriteti ovog programa su pružanje pomoći zemljama korisnicima u ispunjavanju političkih, ekonomskih i drugih kriterijuma koji se odnose na usvajanje pravnih tekovina EU, izgradnju administrativnih kapaciteta i jačanje pravosuđa, kao i pomoć zemljama u procesu pripreme za korišćenje strukturnih i kohezionih EU fondova nakon pristupanja Evropskoj uniji. IPA programi pomoći zamišljeni su da pruže podršku zemljama korisnicima u njihovim naporima za jačanje demokratskih institucija i vladavine prava, reformi državne uprave, reformi privrede, poštovanju ljudskih i manjinskih prava, promovisanju ravnopravnosti među polovima, jačanju civilnog društva, unapređenju regionalne saradnje, postizanju održivog razvoja i smanjenju siromaštva.

${ }^{175}$ Diplomarius, Zapadnobalkanska šestorka + 2, Podgorica, br. 1, 2013, str. 46-48.
} 
ne napustiti njene najstarije članice: Češka, Slovačka, Poljska, Mađarska i Slovenija, a 2007. godine Rumunija i Bugarska. U međuvremenu, deo ovog programa postaće i Makedonija (2006), posle čega je doneta odluka (na inicijativu Evropske komisije i PSuJIE) da se on proširi i na Zapadni Balkan. Na temelju regionalnog Memoranduma o trgovinskoj liberalizaciji, potpisanog u Ženevi 2001. godine, koji je obavezao balkanske države da potpišu bilateralne ugovore o slobodnoj trgovini, ${ }^{176}$ decembra 2006. godine u Bukureštu je zaključen novi (modernizovani) sporazum CEFTA. Tim činom zemlje članice su se obavezale da će do 31. decembra 2010. godine uspostaviti međusobnu zonu slobodne trgovine. ${ }^{177}$ Članice organizacije CEFTA 2007. godine postaće i Albanija, Bosna i Hercegovina, Crna Gora, Hrvatska, Srbija, Moldavija i Kosovo (UNMIK).

Taj sporazum stvoriće uslove za ravnomerniji razvoj Zapadnog Balkana, kao i za jačanje međudržavne saradnje i solidarnosti. Samo godinu dana pre toga, poslednji premijer SFRJ Ante Marković je, u svojoj beogradskoj izjavi, predložio balkanskim liderima sličan oblik saradnje: „Zašto se ne bi razgovaralo o nekoj vrsti, neću reći carinske unije, već određenih carinskih benificija, da se ove naše jadne privrede koje su preostale iz vremena u kome su bile mnogo jače nego što su danas - zaposle, da međusobno više kupuju, da međusobno više prodaju, da zaposle radnike tih zemalja!" lako će program uticati na poboljšanje opšte slike regiona u inostranstvu, javljaju se i određeni problemi u njegovom funkcionisanju. Posebno će biti sporan bosansko-hercegovački Zakon o zaštiti poljoprivrednih proizvoda u odnosu na Hrvatsku i Srbiju, koji nije bio u korelaciji sa odredbama sporazuma CEFTA. Nastupiće i političko-tehnički problemi (korišćenje carinskih potvrda i sl.) nakon proglašenja nezavisnosti Kosova. Istovremeno, BiH će negodovati zbog visokih carinskih stopa (od 10\%) koje je uvela „vlada” Kosova na robu koja dolazi iz $\mathrm{BiH}$. Uprkos navedenim problemima, ukupan obim trgovine u zemljama članicama CEFTA u periodu od 2004. do 2008. godine je - udvostručen. Prema analizi Svetske banke iz 2009. godine, međusobni izvoz u okviru programa CEFTA dostigao je respektabilan procenat u bruto nacionalnom dohotku pojedinih balkanskih država. U Makedoniji je iznosio $14,2 \%$ od ukupnog BND-a, u Bosni i Hercegovini $12,1 \%$, u Srbiji 7,2\%. ${ }^{178}$

Institucionalna saradnja na Balkanu u poslednjih desetak godina takođe je doživela značajan napredak. U tom smislu, posebno su važni elementi parlamentarne saradnje kroz tri regionalne inicijative: Regionalni sekretarijat za parlamentarnu saradnju u Jugoistočnoj Evropi sa sedištem u Sofiji; Cetinjski parlamentarni forum, sa sedištem na Cetinju, te Konferencija parlamentarnih odbora za evropsku integraciju država obuhvaćenih Procesom stabilizacije i pridruživanja Jugoistočne Evrope (KOSAP), osnovana u Sarajevu.

U kontekstu vojno-odbrambene, policijske i sudske saradnje, danas egzistira nekoliko inicijativa: Proces saradnje ministara odbrane; Konferencije načelnika generalštabova zemalja Balkana; Centar za sigurnosnu saradnju; Forum za pomoć zemljama Jugoistočne Evrope; Centar za kontrolu malog i lakog naoružanja; Regionalna antikorupcijska inicijativa; Regionalna inicijativa za migracije, azil i izbeglice; Udruženje šefova policije Jugoistočne Evrope; Policijski forum; Konvencija o policijskoj saradnji u Jugoistočnoj Evropi; Mreža žena policijskih službenika; Mreža javnih tužioca na području Zapadnog Balkana itd.

\footnotetext{
${ }^{176}$ E. Busek, B. Kühne, From Stabilization to Integration, The Stability Pact for SEE, Beč, 2010, str.137-147.

${ }^{177}$ D. Lopandić, J. Kronja, Regionalne inicijative i multikateralna saradnja na Balkanu, str. 118.

${ }^{178}$ B. Handjiski, Enhancing Regional Trade Integration in SEE, Washington, World Bank Working Papers, 185, 2009.
} 
Saradnja civilnog sektora predstavlja važan aspekt međudržavnog povezivanja na Balkanu. Nekoliko civilnih udruženja i mreža predstavljaju značajne karike u savladavanju političkih problema i nesporazuma koji su ostavili posledice u ovom regionu. Među njima su i: Igmanska inicijativa, Organizacija multietničkih gradova Jugoistočne Evrope, Civilni dijalog, Asocijacija CIVIS, Koalicija za regionalnu komisiju (REKOM) i dr. Balkanske države su praktikovale saradnju i u onim inicijativama koje se ne ograničavaju isključivo na balkanski geografski prostor, kao što su Organizacija za crnomorsku ekonomsku saradnju, Srednjoevropska inicijativa, Jadransko-jonska inicijativa itd.

Osim tendencija za integracijom zemalja Balkana na regionalnom nivou, aktuelna je i njihova integracija u Evropsku uniju i NATO. Grčka, Rumunija, Bugarska, Hrvatska i Slovenija su članice EU, dok su preostale zemlje (Makedonija, Crna Gora i Srbija) dobile status kandidata za članstvo i otpočele pristupne pregovore, ili sa statusom kandidata. Bosna i Hercegovina je u junu 2008. godine potpisala Ugovor o pridruživanju sa EU, ali zbog složene političke situacije na unutrašnjem planu još uvek nije podnela zahtev za članstvo. U decembru 2009. godine EU je uvela viznu liberalizaciju za građane Crne Gore i Srbije njihovim stavljanjem na „belu” šengensku listu, a naredne godine proširiće je i na Albaniju i Bosnu i Hercegovinu. Osim toga, većina balkanskih država članice su NATO-a. Neke su, pre ili kasnije, na putu da to postanu, dok je Srbija u decembru 2006. godine pristupila Partnerstvu za mir - političko-vojnom programu NATO-a, radi ostvarivanja vojne saradnje sa ostalim evropskim državama. U decembru 2007. godine Narodna skupština Republike Srbije proglasila je neutralnost u odnosu na sve postojeće vojne saveze.

Imajući u vidu aktuelnu situaciju, potrebno je naglasiti da se Zapadni Balkan i dalje suočava sa veoma ozbiljnim političkim, ekonomskim i bezbednosnim izazovima: makedonsko pitanje, unutrašnja nefunkcionalnost Bosne i Hercegovine, odnosi između Beograda i Prištine, Beograda i Zagreba, međudržavni granični sporovi... Važno je zapitati se: da li će se ti problemi rešiti integracijom u okviru Evropske unije i NATO-a, ili je bolje najpre pokušati, putem međudržavne saradnje, pronaći rešenje za neke od problema s kojima se zemlje zapadnog Balkana i dalje suočavaju. Ovde se vraćamo na sam početak naše priče.

\section{Izvori i literatura}

[1] Svetozar Marković, Srbija na Istoku, Beograd, 1965.

[2] Dimitrije Mita Cenić, Izabrani spisi, Beograd, 1988.

[3] Sergije Dimitrijević, Socijalistički radnički pokret u Srbiji 1870-1918, Beograd, 1982.

[4] Dimitrije Tucović, Izabrani spisi, knjiga I-II, Beograd, 1950.

[5] Dimitrije Tucović, Srbija i Arbanija. Jedan prilog kritici zavojevačke politike srpske buržoazije, Beograd, 1914; Isto, Reprint izdanje, Zemun, 2011.

\footnotetext{
${ }^{179}$ Zoran Dragišić, stručnjak za pitanja vojne bezbednosti, u februaru 2010. godine je tvrdio kako je Srbija neutralna samo na papiru: „da bi smo zadržali poziciju neutralnosti, treba da budemo nautralni. Mi to, međutim, nismo, jer ona nije potvrđena ni jednim međunarodnim ugovorom, kao u sličaju Švajcarske, Austrije i Švedske (...) NATO je svuda oko nas. To više nije samo vojni, već i politički, pa i ekonomski savez. Pitanje našeg članstva u Alijansi se otvoreno postavlja, pogotovo ako ćemo u EU. Verujem da će pritisci Rusije prestati čim predamo kandidaturu za ulazak u NATO, kao što je to bilo i u slučaju Rumunije i Bugarske". Slično razmišlja i vojni analitičar Aleksandar Radić: „Moraćemo da se odredimo da li ćemo u Alijansu ili ne, jer neutralnost ne postoji i niko je ne priznaje. NATO nema alternativu". (unos na: "Blic online", 18. 02. 10.; url: http://www.blic.rs/Vesti/Tema-Dana/177190/Vojni-analiticari-Srbija-je--neutralna-samo-na-papiru).
} 
Iskustva i pouke iz prošlosti

[6] Nikola Popović, Dimitrije Tucović: njegov život i rad, Beograd, 2014.

[7] Istorijski arhiv KPJ, knj. II, Zbornik dokumenata, Beograd, 1950.

[8] Mirjana Zorić, Srbi u nacionalnoj politici KPJ između dva rata i u Drugom svetskom ratu, Svarog, časopis za društvene i prirodne nauke, Nezavisni univerzitet Banja Luka, br. 1, 2010.

[9] Ljubodrag Dimić, Istorija srpske državnosti, Srbija i Jugoslavija, knj. III, Beograd, 2001.

[10] Branislav Gligorijević, Kominterna, jugoslovensko i srpsko pitanje, Beograd, 1992.

[11] Desanka Pešić, Jugoslovenski komunisti i nacionalno pitanje 1919-1935, Beograd, 1983.

[12] Veselim Đuretić, Upotreba Rusije i zapada, Obmane saveznika zarad velikohrvatske politike, Beograd, 1997.

[13] Branko Petranović, Jugoslovensko iskustvo srpske nacionalne integracije, Beograd, 1993.

[14] Branko Petranović, Balkanska federacija 1943-1948, Beograd, 1991.

[15] Branko Petranović, Istorija Jugoslavije 1918-1988, knj. 1-3, Beograd, 1988.

[16] Danijela D. Popović, Rezolucija Informbiroa i 1948. godina u očima ruskih istoričara i istraživača, feljton u listu Dan, od 8. do 18. marta 2008.

[17] Aleksandar Životić, Pitanje Albanije u odnosima Jugoslavije i Zapada 1945-1947, Istorija 20. veka, Beograd, 2010.

[18] Aleksandar Životić, Jugoslavija i jačanje sovjetskog uticaja u Albaniji (1947-1948), Institut za noviju istoriju Srbije, Beograd, 2007.

[19] Aleksandar Životić, Otvaranje albanskog pitanja u Jugoslaviji u senci sukoba između Jugoslavije i Informbiroa 1948-1954, Istorija 20. veka, br. 2, Beograd, 2009.

[20] Josip Broz Tito, Sabrana djela, tom 18, Beograd, 1982.

[21] Branko Petranović, Jugoslovensko-albanski odnosi 1945-1948. i naše manjine u NR Albaniji; U: Stanovništvo slovenskog porekla u Albaniji, Zbornik radova sa međunarodnog naučnog skupa održanog na Cetinju 21-23. juna 1990.

[22] Aleksandar Životić, Jugoslovensko-sovjetske vojne suprotnosti (1947-1957), Beograd, 2015.

[23] Jerzi Holzer, Komunizam u Evropi, povijest pokreta i sustava vlasti, Zagreb, 2002.

[24] Branko Petranović, Srbija u Drugom svetskom ratu 19339-1945, Beograd, 1992.

[25] Todor Kulić, Tito, Sociološko-istorijska studija, Beograd, 1988.

[26] Dokumenti o spoljnoj politici SFRJ 1941-1945, knj. II, Beograd, 1989.

[27] Zbornik dokumenata i podataka o narodnooslobodilačkom ratu naroda u narodnosti Jugoslavije (kraće: Zbornik NOR-a), Vojnoistorijski institut, tom 1, knjiga 2, Beograd, 1949.

[28] AVNOJ i revolucija, Zbornik dokumenata, Priredili B. Petranović i S. Nešović, Beograd, 1983.

[29] Branko Petranović, Momčilo Zečević, Jugoslovenski federalizam - ideje i stvarnost, 1, Beograd, 1987.

[30] Budislav Vukas, Prijedlozi i nacrti konfederalizacije Jugoslavije 1990/91 - posljednji pokušaji „spašavanja” zajedničke države, Zbornik Pravnog fakulteta Sveučilišta u Rijeci, v. 27, br. 2, 2006.

[31] Momčilo Diklić, Srbi u Hrvatskoj 1945-1991: period potiranja nacionalnog identiteta, Institut za evropske studije, Beograd, 2007.

[32] Dejan Jović, Yugoslavia: A State that Withered Away (Jugoslavija: država koja je odumrla u papiru), Purdue University Press, 2009.

[33] Mihailo Đurić, „Smišljene smutnje”, Anali Pravnog fakulteta u Beogradu,3/1971.

[34] Dejan Jović, Jugoslavija - država koja je odumrla - uspon, kriza i pad Kardeljeve Jugoslavije (1974-1990), Prometej, Zagreb, 2003.

[35] Borisav Jović, Poslednje dani SFRJ, drugo izdanje, Beograd, 1996. 
[36]"Jugoslavija á la carte", Plan lorda Karingrona, www.camo.ch/sj_jugoslavija.htm

[37] Saša Knežević, Nikola Zečević „Multiratelarne inicijative na Balkanu u razdoblju između 1995. i 2015. godine", Međunarodne studije, časopis za međunarodne odnose, vanjsku politiku i diplomaciju Centra za međunarodne studije u Zagrebu, Hrvatske udruge za međunarodne studije i Visoke škole međunarodnih odnosa i diplomacije Dag Hamaršeld (Dag Hammarskjöld), vol. 15, br. 2/1015.

[38] Josip Glaurdić, The Hour of Europe: Western Powers and the Breakup of Yugoslavia. London: Yale University Press. 2011.

[39] Grubačić, Andrej, Don't Mourn, Balkanize!: Essays After Yugoslavia, PM Press, 2010.

[40] Duško Lopandić, Jasminka Kronja, Regionalne inicijative $i$ multilateralna saradnja na Balkanu, Beograd, 2010.

[41] Anđelko Milardović, Pod globalnim šeširom, Zagreb, Centar za politološka istraživanja, 2004.

[42] E. Busek, B. Kühne, From Stabilization to Integration, The Stability Pact for SEE, Beč, 2010.

[43] Human Rights Watch, Not on the Agenda, The Continuing Failure to Address Accountability in Kosovo Post-March 2004, s.l., Human Rights Watch, svezak 18, str. 6, 2006. 